UNIVERSIDADE DE SÃO PAULO

FACULDADE DE FILOSOFIA, LETRAS E CIÊNCIAS HUMANAS

DEPARTAMENTO DE LINGUIÍSTICA

Programa de Pós-Graduação em Linguística

JULIANA ÁNGEL-OSORNO

Descrição de narrativas em espanhol de Aldana (Colômbia): o comportamento do PONTO DE VISTA segundo a Teoria de Espaços Mentais

Versão Corrigida

São Paulo

2016 


\section{JULIANA ÁNGEL-OSORNO}

Descrição de narrativas em espanhol de Aldana (Colômbia): o comportamento do PONTO DE VISTA segundo a Teoria de Espaços Mentais

Versão corrigida

Dissertação apresentada à Faculdade de Filosofia, Letras e Ciências Humanas da Universidade de São Paulo para obtenção do título de Mestre em Letras pelo Programa de Pós-Graduação em Linguística.

Área de Concentração: Semiótica e Linguística Geral

Orientadora: Profa. Dra. Evani de Carvalho Viotti

São Paulo

2016 
Dissertação de autoria de Juliana Ángel-Osorno, sob o título "Descrição de narrativas em espanhol andino colombiano de Aldana", apresentada à Faculdade de Filosofia, Letras e Ciências Humanas da Universidade de São Paulo, para obtenção do título de Mestre em Letras pelo Programa de Pós-Graduação em Linguística, na área de concentração Semiótica e Linguística Geral, aprovada em de de pela comissão julgadora constituída pelas doutoras:

Profa. Dra. Evani de Carvalho Viotti

Presidente

Instituição: Universidade de São Paulo

Profa. Dra. Adriana Maria Tenuta de Azevedo Instituição: Universidade Federal de Minas Gerais

Profa. Dra. Mariana Luz Pessoa de Barros Instituição: Universidade de São Paulo 


\section{AGRADECIMENTOS}

Agradeço primeiramente a minha orientadora Evani Viotti, sem a qual este trabalho jamais teria sido realizado. Obrigada por me aceitar como aluna de IC recém chegada da Colômbia, pelas aulas interessantíssima e as discussões profundas, e pela oportunidade de fazer o mestrado aqui sob a sua orientação. Obrigada também pela paciência, pela preocupação com o meu bem-estar, e por colocar meus pés na terra sempre que as coisas estavam ficando difíceis.

Agradeço também aos meus pais, Carlos e Mariela, por ter me ensinado que eu posso ser o que eu quiser na vida. Também por terem me criado em uma casa cheia de livros, o que gerou em mim o amor por histórias. Especialmente agradeço a eles o amor e o apoio que fez com que eu me sentisse menos longe de casa sempre.

Agradeço a minha irmã, Ana María, pelas infinitas conversas no Skype. Por estar sempre aí nas crises e nos momentos bons também.

Á Valentina por ter confiado em mim para trabalhar com seus dados de pesquisa e com o corpus do seu trabalho de campo em Aldana. Também pelas discussões sempre intensas sobre o tempo, e claro, pela amizade constante.

Quero agradecer ao Professor Leland McCleary pelas aulas e pelas discussões e textos interessantíssimos e dificílimos que me apresentou. Também agradeço a ele pelo interesse constante na minha pesquisa.

Aos Professores Lynn Mario de Souza e Margarida Petter pelas disciplinas de pósgraduação que me permitiram discutir assuntos que pareciam, no inicio, distantes da minha pesquisa mas que terminaram sendo temas tangenciais que nutriram muito este documento e minha visão sobre as narrativas e sua emergência.

Agradeço também às Professoras Adriana Maria Tenuta de Azevedo e Mariana Luz Pessoa de Barros pela leitura atenta da minha qualificação e pelos comentários. Muito do que este documento é hoje se deve à discussão com elas em aquela ocasião. 
Ao Danilo Paiva Ramos também pelos comentários no meu exame de qualificação, e muito mais pelas discussões interessantíssimas no GEAL sobre a interface Antropologia-Linguística. Aproveito para estender meu agradecimento a todos os meus colegas do GEAL por terem enchido minha cabeça de interrogantes nesse último ano de mestrado.

Aos colegas do LLIC: Thais, João, Cacilda, Renata, Fernanda, Ivan. Obrigada pelo espaço e pelas discussões sobre linguística cognitiva, que mudaram muito do que eu achava quando começou esse processo, e não poderia ter acontecido nada melhor!

Quero agradecer ao Departamento de Linguística por ter sido um lugar em que sempre me senti em casa. Embora eu tenha chegado faz pouco tempo, tanto os professores como os funcionários e meus colegas me fizeram sentir parte da turma sempre. Agradeço especialmente à Denise e o Robson pela atenção e a boa disposição sempre.

À Érika Lima agradeço infinitamente por estar sempre aí para me guiar pelo difícil caminho da burocracia e por ter me salvado em mais de uma ocasião. Sem ela eu não teria conseguido terminar o mestrado.

Finalmente agradeço aos amigos que são minha família longe de casa. Ao Rodrigo, meu irmão de mestrado, por estar sempre mais informado sobre os acontecimentos académicos e burocráticos e por não me deixar esquecer nada. Também pela calma sempre e o bom humor, e pelas eternas conversas sobre tempo e espaço. Obrigada também por todas as recomendações bibliográficas e pela pequeníssima educação futebolística que tenho hoje. À Júlia por abrir as portas da sua casa para mim e pelo carinho, as músicas, as fofocas e as conversas sobre a pós-graduação. À Cecília, Isadora, Bruno, Juliana Veneziano, Juliana Forastieri, Bia, Thiago, Camila, Pamela, Rafael Veloso, Rafael Zanatto, Marcellus e Alfredo pelo amor, as cervejas, as conversas, as comidas. É por vocês todos que São Paulo é minha casa. 


\section{Resumo}

ÁNGEL-OSORNO, Juliana. Descrição de narrativas em espanhol de Aldana (Colômbia): o comportamento do PONTO DE VISTA segundo a Teoria de Espaços Mentais. 2016. 141 f. Dissertação (Mestrado em Letras)- Faculdade de Filosofía, Letras e Ciências Humanas, Universidade de São Paulo, São Paulo, 2016.

O objetivo desta dissertação é descrever o comportamento do primitivo discursivo PONTO DE VISTA como proposto na teoria de espaços mentais (FAUCONNIER 1994, 1997) em duas narrativas em espanhol andino colombiano de Aldana. As narrativas foram extraídas de um corpus de entrevistas etnográficas colhido por Valentina Arango Villalón em 2011, em Aldana, na fronteira sul da Colômbia. Essas narrativas são fruto de uma entrevista feita por Arango Villalón e colegas com Manuel Erira, indígena pasto habitante da Reserva Indígena Pasto de Pastás em Aldana. Nelas, Erira explica a proveniência de alguns mitos e conta a história dos antepassados. Transcrevi as narrativas utilizando o software ELAN (desenvolvido pelo Max Planck Institute for Psycholinguistics) e utilizando unidades entoacionais (CHAFE, 1994) como unidade de segmentação do fluxo da fala. Uma vez transcritas as narrativas, apliquei o modelo da etnopoética de Hymes (1994), que resultou na organização das narrativas segundo a sucessão e repetição de elementos significativos da estruturação da ação. Finalmente, apliquei o modelo de espaços mentais à análise das duas narrativas seguindo as propostas de Fauconnier (1994, 1997), Cutrer (1994), Doiz-Bienzobas (1995), Tenuta (2006) e Tenuta e Lepesqueur (2014), dando especial atenção ao comportamento do primitivo discursivo PONTO DE VISTA. Discuti a possibilidade de compatibilizar a noção de PONTO DE VISTA como descrita no modelo de espaços mentais com o conceito de focalização no estudo de narrativas proposto por Genette (1980). Esta dissertação aponta para a possibilidade de que o primitivo PONTO DE VISTA seja uma categoria híbrida que descreve, em um primeiro momento o espaço mental a partir do qual outros espaços mentais são criados/acessados, e em um segundo momento o espaço a partir do qual se conceitualizam os eventos sendo elaborados no espaço FOCO. A dissertação mostra também como a proposta de Doiz-Bienzobas (1995), de que os espaços IMPERFECTIVOS têm um PONTO DE VISTA interno associado a um self-experienciador, se relaciona com a segunda característica do primitivo discursivo em questão, ou seja, ser o espaço a partir do qual se conceitualizam os eventos sendo elaborados no espaço FOCO. Finalmente, a dissertação mostra como o conceito de focalização em Genette (1980) não é equiparável ao primitivo discursivo PONTO DE VISTA no modelo de espaços mentais.

PALAVRAS CHAVE: PONTO DE VISTA. Narrativas. Teoria de espaços mentais. Espanhol andino. Semântica cognitiva. 


\begin{abstract}
ÁNGEL-OSORNO, Juliana. Description of narratives in the Spanish of Aldana (Colombia): The behavior of VIEWPOINT according to Mental Space Theory. 2016. 141f. Master's Thesis) -Faculty of Philosophy, Languages, and Human Sciences, University of São Paulo, São Paulo, 2016.
\end{abstract}

The objective of this dissertation was to describe the behavior of the VIEWPOINT discourse primitive, as proposed by mental spaces theory (FAUCONNIER 1994, 1997), in two narratives in Colombian Andean Spanish from Aldana. The narratives are part of a corpus of ethnographic interviews collected by Valentina Arango Villalón in 2011 in Aldana, on the southern border of Colombia. The narratives emerged in an interview conducted by Arango Villaón and colleagues with Manuel Erira, native to the Pasto Indigenous People of Pastás, in Aldana. In the narratives, Erira explains the origins of some myths and tells the story of his predecessors. I transcribed the narratives using ELAN (developed by the Max Planck Institute for Psycholinguistics) and the concept of intonation units (CHAFE, 1994) as units for the segmentation of the speech flow. I used Hymes's(1994) model of ethnopoetics for the analysis of narrative structure, which resulted in an organization that responded to the succession and repetition of meaningful elements of action structure. I applied the model of mental spaces following Fauconnier (1994, 1997), Cutrer (1994), Doiz-Bienzobas (1995), Tenuta (2006) and Tenuta \& Lepesqueur (2014), giving special attention to the discourse primitive VIEWPOINT. I discussed the possibility of matching the concept of VIEWPOINT as described in mental space theory and the concept of focalization as proposed by Genette (1980) in his study of narrative discourse. This dissertation shows the possibility of VIEPOINT being a hybrid category that describes first the mental space from which other spaces are created/accessed, and secondly the mental space from which the events described in FOCUS space are conceptualized. The dissertation also shows how DoizBienzobas' (1995) statement that IMPERFECTIVE spaces show an internal VIEWPOINT associated with an experiencer-self has to do with the second characteristic of VIEWPOINT stated above, namely that of VIEW POINT being the space from which events in FOCUS space are conceptualized. Finally, the dissertation shows how the notions of VIEWPOINT in mental space theory and focalization in Genette's (1980) are not equivalent.

KEY WORDS: VIEW POINT. Narratives. Mental Space Theory. Andean Spanish. Cognitive semantics. 


\section{Lista de figuras}

Figura 1 Trilhas utilizadas na transcrição da fala de Manuel Erira (F1) no software ELAN. F1: Falante 1; F1-V: Falante 1, Verbos Isolados; F1-ADV-T: Falante 1, Advérbios temporais isolados; F1-V-GT: Falante 1, Formas verbais segundo a gramática tradicional do espanhol; F1-T-REICH: Falante 1, Cálculos temporais

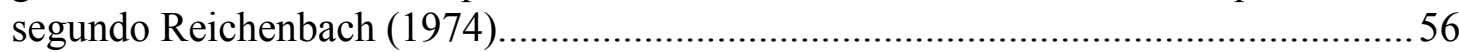

Figura 2 Transcrição extraída do ELAN com marcação temporal......................................58 Figura 3 Organização de referências temporais no discurso em termos de anterioridade e posterioridade, segundo proposta de Reichenbach (1974) ..........................................62

Figura 4 Criação do espaço do narrador e do espaço BASE desenvolvida a partir da

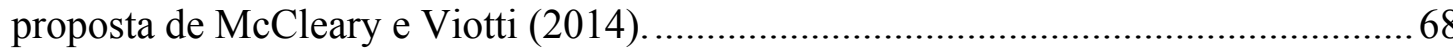

Figura 5 Cálculos temporais do espaço EVENTO. (a) na ausência do espaço EVENTO;

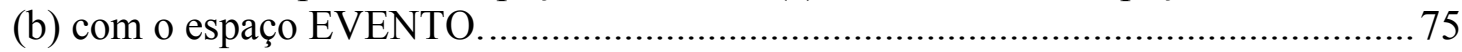

Figura 6 Rede de espaços mentais completa para a historinha da Maria. ........................... 79

Figura 7 Elaboração interna dos espaços mentais apresentados na Figura 4. ..................... 79

Figura 8 Mapeamento de espaços mentais: sentenças (3) e (4) ......................................... 81

Figura 9 Mapeamento de espaços mentais: sentenças (5), (6) e (7) .................................. 87

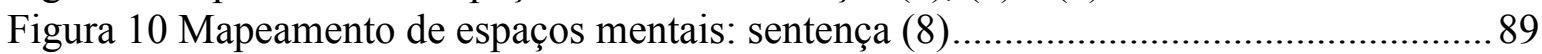

Figura 11 Mapeamento de espaços mentais: sentença (9) .................................................. 91

Figura 12 Criação do espaço do narrador EN a partir do espaço da enunciação EE e o espaço frame narrativo EFN ......................................................................................93

Figura 13 Mapeamento de espaços mentais narrativa $A$ viúva e os duendes: unidades

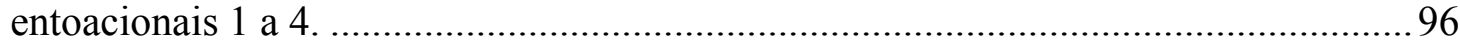

Figura 14 Mapeamento de espaços mentais narrativa A viúva e os duendes: unidades entoacionais 5 a 15.

Figura 15 Mapeamento de espaços mentais narrativa A viúva e os duendes: unidades

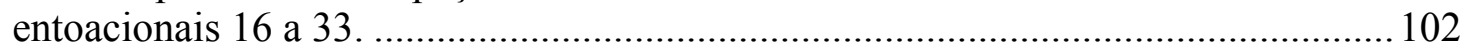

Figura 16 Mapeamento de espaços mentais narrativa A viúva e os duendes: unidades

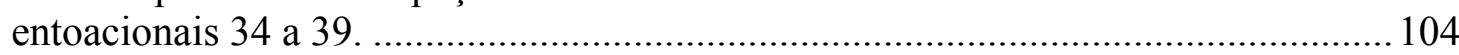

Figura 17 Mapeamento de espaços mentais narrativa $A$ viúva e os duendes: unidades

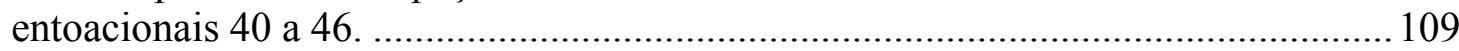

Figura 18 Mapeamento de espaços mentais narrativa $A$ viúva e os duendes. .................... 110

Figura 19 Mapeamento de espaços mentais narrativa Índios enterrados: unidades

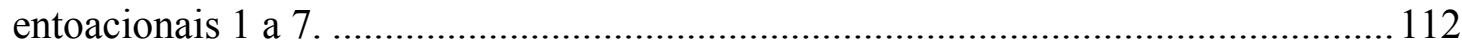

Figura 20 Mapeamentos de espaços mentais narrativa Índios enterrados: unidades entoacionais 8 a 14.

Figura 21 Mapeamento de espaços mentais narrativa Índios enterrados: unidades entoacionais 15 a 17.

Figura 22 Mapeamento de espaços mentais na narrativa Índios enterrados: unidades

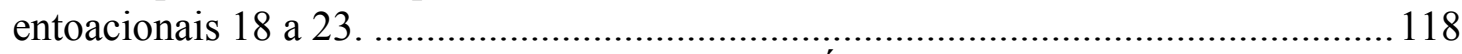

Figura 23 Mapeamento de espaços mentais narrativa Índios enterrados: unidades entoacionais 24 a 32.

Figura 24 Mapeamento de espaços mentais narrativa Índios enterrados. 


\section{Lista de mapas}

Mapa 1 O mapa A mostra a localização do Município de Aldana no mapa do

Departamento de Nariño; o mapa B mostra a localização desse Departamento na Colômbia. .....

Mapa 2 Localização dos núcleos de língua inga atualmente na Colômbia. Informações adquiridas no Portal de Lenguas de Colômbia.

Mapa 3 Expansão do império incaico. Informações tomadas de Cerrón Palomino (1987). À direita se mostra a expansão do mapa que mostra a relação da área ocupada pelo império e Aldana, o município que interessa à pesquisa.

Mapa 4 Área proposta por Calero (1997) do território ocupado pelos indígenas pastos à chegada dos espanhóis ao norte dos Andes. (A) atual Município de Aldana; (B) Carchi, Equador: limite sul; (C) Yaramal, Colômbia: limite sudeste; (D) Funes, Colômbia: limite nordeste; (E) Ancuya, Colômbia: limite norte; (F) Yascual, Colômbia: limite noroeste; (-) Fronteira Colômbia-Equador.

\section{Lista de tabelas}


Tabela 1 Relação de indígenas e espanhóis no século XVI na zona de influência do atual Departamento de Nariño. As informações das colunas Visitas e Indígenas são de Calero (1997) e as das colunas restantes de Boyd-Bowman (1976); (*) os dados da visita do Visitador Centellas estão incompletos; $(* *)$ SD: sem dados.

Tabela 2 Tabela demográfica da região de Ipiales para 1809, tomada de Narváez

Ramíres (2006, p.26).

Tabela 3 Elementos da narrativa e sua correspondência com unidades dentro da narrativa da Viúva e o Duende.

Tabla 4 Elementos da narrativa e sua correspondência com unidades dentro da narrativa Índios enterrados. Comparação com a narrativa A viúva e os duendes.

Tabela 5 Vocabulário controlado. Trilha F1-V-GT. Categorías da Nueva Gramática de la Lengua Española (2010).

Tabla 6 Vocabulário controlado. Trilha F1-V-REICH. Categorías temporais adaptadas de Reichenbach (1974). 
Sumário

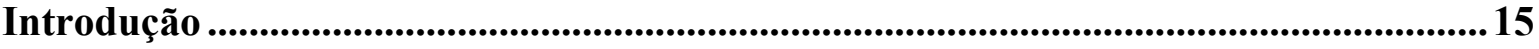

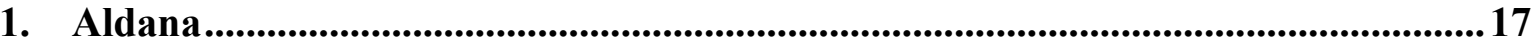

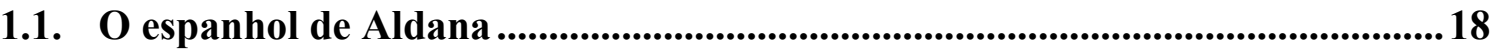

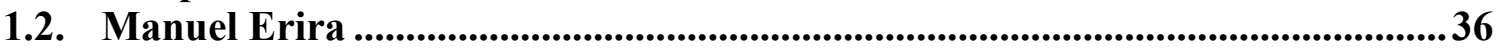

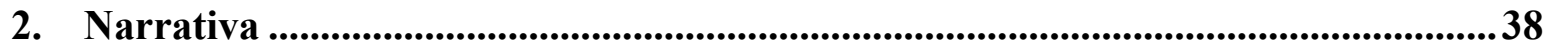

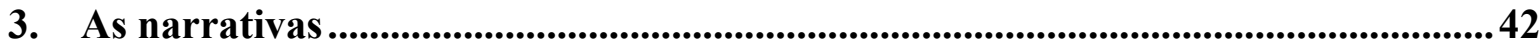

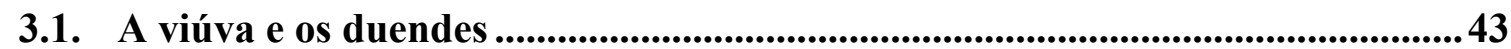

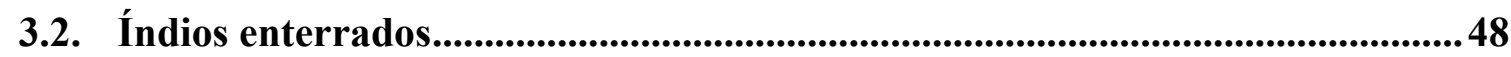

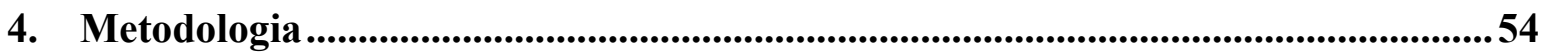

4.1. Obtenção e natureza dos dados .....................................................................................54

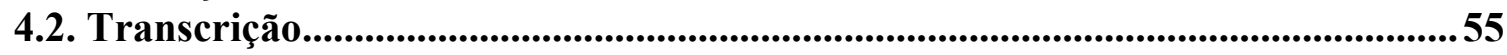

5. Teoria de espaços mentais: expansão e aplicação ao estudo de narrativas............ 65

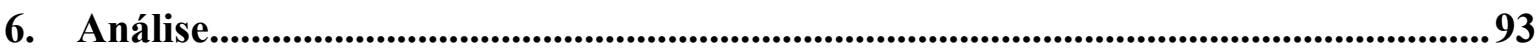

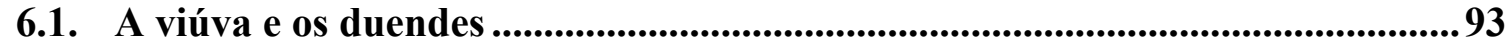

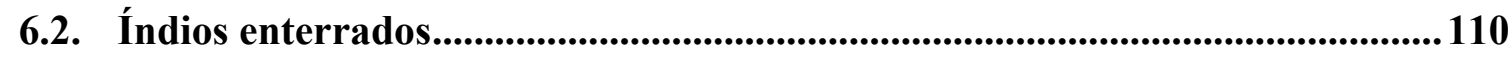

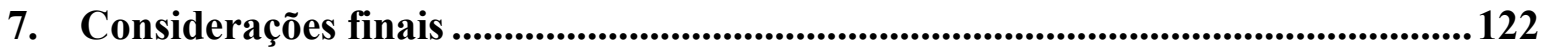

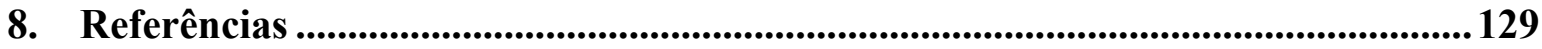

Anexo 



\section{Introdução}

Essa dissertação é o documento final da minha pesquisa de mestrado, que discute a dinâmica de ponto de vista em duas narrativas obtidas a partir de um corpus de entrevistas colhido por Valentina Arango Villalón em 2011, na Reserva Indígena Pasto de Pastás em Aldana, Colômbia. A análise das narrativas foi feita a partir do modelo de análise linguística da teoria de espaços mentais, seguindo a proposta de Fauconnier (1994, 1997), Cutrer (1994) e Doiz-Bienzobas (1995).

O objetivo principal da pesquisa foi descrever o funcionamento do primitivo discursivo PONTO DE VISTA (FAUCONNIER 1994, 1997) nas narrativas de Aldana. Como objetivo secundário, a pesquisa teve também o de discutir a possibilidade de compatibilizar o que Genette (1980) chama de focalização no discurso narrativo com a noção de ponto de vista na teoria de espaços mentais, e especialmente com os conceitos de self narrador e self experienciador propostos por Doiz-Bienzobas (1995). O documento se estrutura da maneira descrita a seguir.

No primeiro capítulo situo a Reserva Indígena Pasto de Pastás em Aldana. Nele, faço uma breve descrição de onde se localiza o Município de Aldana na Colômbia e dos modos de vida dos seus habitantes. No item 1.1 discuto a variedade de espanhol falada na região a partir de uma análise sócio-histórica das condições de contato do espanhol com as línguas indígenas no sul da Colômbia seguindo a proposta de Mufwene (2008). No item 1.2 ofereço brevemente as informações que tenho sobre Manuel Erira, o indígena pasto que conta as narrativas que analiso na pesquisa.

No segundo capítulo, descrevo o que entendo como narrativa nesta pesquisa seguindo a proposta de Genette (1980), e discuto as análises de narrativa de experiência pessoal de Labov e Waletzky (1967) e Tenuta (2006). Discuto ainda a importância que a narrativa tem para a identidade individual e grupal, seguindo as propostas de Bruner (2002, 2004), e a análise de narrativas indígenas de Klapproth (2004). 
No terceiro capítulo apresento as narrativas que foram analisadas durante a pesquisa. $\mathrm{O}$ item 3.1 apresenta a narrativa $A$ viúva e os duendes, na qual Manuel Erira conta quem são esses personagens míticos. A viúva é um espírito que eles chamam de espírito dos apaixonados, que engana o namorado fingindo ser a namorada. Já os duendes são espíritos que eram os anjos que serviam no exército de Lúcifer, quando ele, ainda sendo anjo, decidiu enfrentar Deus. Nesse enfrentamento, o Anjo São Rafael também ia a ser expulso do céu, mas para que isso não acontecesse, Deus expulsou os outros anjos e esses se converteram nos duendes. O item 3.2 apresenta a narrativa Índios enterrados, que conta a história dos indígenas que se enterraram para se salvar dos conquistadores espanhóis, pois achavam que se enterrando iriam sobreviver; mas morreram asfixiados. De um ponto de vista da forma, as duas narrativas são tratadas a partir da proposta da etnopoética de Hymes (1994).

O capítulo quatro apresenta a metodologia da pesquisa. $\mathrm{O}$ item 4.1 descreve como foi feita a obtenção dos dados e qual é a sua natureza. A seção 4.2 descreve como foi feita a transcrição utilizando o software ELAN e o conceito de unidades entoacionais de Chafe (1994).

No quinto capítulo apresento o funcionamento do modelo de espaços mentais proposto por Fauconnier (1994, 1997) e Cutrer (1994). Também discuto a proposta de Doiz-Bienzobas (1995) de que a diferença entre Pretérito Perfeito e Imperfeito em espanhol significa uma diferença de ponto de vista, na qual o primeiro implica um ponto de vista presente e externo, e o segundo um ponto de vista passado e interno.

No sexto capítulo analiso as narrativas $A$ viúva e os duendes e Índios enterrados segundo o arcabouço teórico explorado no capítulo cinco. Na minha análise dei especial importância para o funcionamento do primitivo discursivo PONTO DE VISTA e a suas implicações no que se refere à construção de significado nas narrativas. Finalmente no capítulo oito apresento as conclusões da pesquisa e os possíveis desenvolvimentos que podem surgir de questões levantadas durante esses dois anos de mestrado. 


\section{Aldana}

As narrativas que analisei durante o mestrado fazem parte de um corpus de gravações obtidas por Valentina Arango Villalón para um estudo etnográfico na Reserva Indígena Pasto de Pastás, em Aldana, em 2011. Aldana é um município do Departamento de Nariño, localizado ao sul da Colômbia, na zona norte dos Andes sul-americanos. Localiza-se perto de Ipiales, cidade fronteiriça com o Equador, no Nó Orográfico dos Pastos, de onde nascem as três cordilheiras que atravessam a Colômbia.

Cerca de $90 \%$ do município de Aldana está ocupado pela Reserva Indígena Pasto de Pastás. A variedade de espanhol falada nessa reserva é parte do interesse desta pesquisa. A reserva conta com 6000 habitantes em um território de $45 \mathrm{~km}^{2}$ e, em termos de altitude, oscila entre 3.500 e 3.800 metros acima do nível do mar (PLAN DE VIDA RESGUARDO DE PASTAS 2006-2007). Seus habitantes possuem minifúndios onde criam gado e cui (uma espécie de pequeno roedor comestível), plantam hortaliças, tubérculos e principalmente batata. São falantes monolíngues de espanhol e não se tem registro de que algum deles fale alguma língua indígena, ou sequer tenha ouvido alguém da comunidade falar. No entanto, eles se reconhecem como indígenas pastos.

O Mapa 1 mostra a localização do Departamento de Nariño na Colômbia (B), e a localização do Município de Aldana no Departamento (A). Como se pode ver, o Departamento faz fronteira com o Equador ao sul, com o Oceano Pacífico a oeste, com o Departamento de Putumayo ao leste e com o de Cauca ao norte. O mapa (A) mostra que o Município de Aldana se encontra perto de Ipiales, a cidade de fronteira do lado colombiano e Tulcán, a cidade de fronteira do lado equatoriano. Os habitantes de Aldana comercializam os seus produtos nos mercados dessas duas cidades fronteiriças. O mapa (A) também mostra a geografia do Departamento. As áreas em verde são as terras baixas que descem da Cordilheira dos Andes até o Oceano Pacífico. Já o amarelo indica as áreas de montanha que compõem o Nó Orográfico dos Pastos. Nelas se encontra a capital do Departamento de Nariño, San Juan de Pasto, e ao sul dela, o Município de Aldana, marcado com a seta e o círculo vermelhos. 
A.

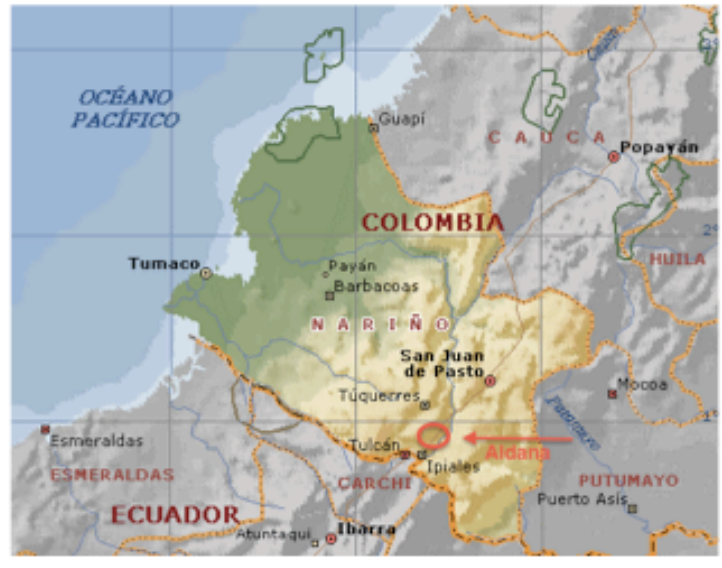

B.

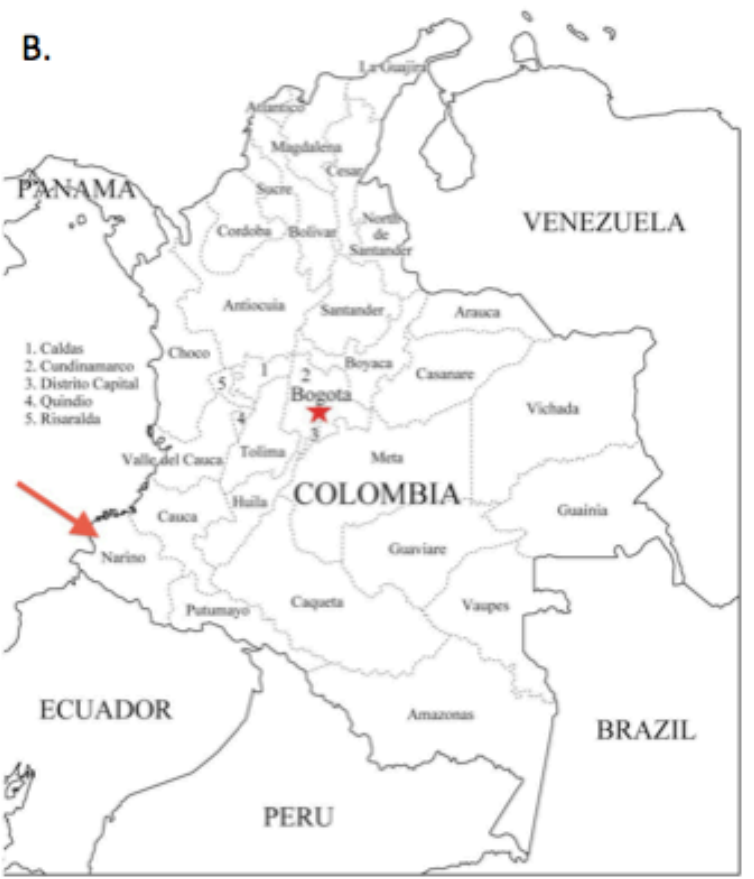

Mapa 10 mapa A mostra a localização do Município de Aldana no mapa do Departamento de Nariño; o mapa B mostra a localização desse Departamento na Colômbia.

Como pode ser visto no mapa, Aldana fica no centro da formação montanhosa, e muito próxima do Equador. Isso será relevante para entender como se formou a variedade de espanhol falada na região, e será desenvolvido no item 1.1. a seguir.

\subsection{O espanhol de Aldana}

Os habitantes de Aldana são monolíngues em espanhol e nenhum deles tem sequer uma lembrança de alguém falando a língua pastás no território. A variedade de espanhol que eles falam difere do padrão do espanhol colombiano, e para mais bem entender e poder analisar as narrativas faço uma pequena descrição de como essa variedade pode ter emergido na região. Além de permitir um melhor entendimento da língua em que se contam as narrativas, essa descrição permitirá também pensar historicamente quem são esses falantes. 
Essa descrição é relevante também porque não há estudos específicos sobre o espanhol de Aldana e poucos são os que têm sido feitos sobre os seus modos de vida. Dentre eles, há o trabalho de Arango Villalón (2012) sobre a concepção de tempo dos indígenas da reserva, a partir de uma perspectiva etnográfica, que se encaixa em um projeto maior sobre essa reserva desenvolvido pelos professores Carlos Páramo e Luis Alberto Suárez Guava na Universidade Nacional da Colômbia. Os estudos sobre o espanhol falado na região se encaixam dentro do estudo do espanhol andino, da perspectiva da linguística de contato; esses estudos estão mais desenvolvidos em países como o Equador, o Peru, a Bolívia e o Chile pelo interesse que desperta o contato intenso do espanhol com o quéchua e o aymará nesses paísses.

De qualquer modo, é possível dizer que contato do espanhol com as línguas ameríndias tem sido amplamente discutido nos estudos de linguística hispânica, devido à grande variedade que o espanhol falado nas Américas apresenta. Uma das explicações para essa grande quantidade de variedades de espanhol tem sido atribuir às centenas de línguas ameríndias do Novo Mundo a responsabilidade pelas diferenças que apresentam os dialetos do espanhol fora da Península Ibérica. Os autores que se debruçaram sobre o assunto reconhecem a influência de centenas de línguas na criação das variedades americanas do espanhol, embora sejam quatro as línguas que se descrevem como mais responsáveis pela variação: o quéchua, as línguas mayas, o náhuatl e as línguas guaranis (ARBOLEDA TORO 2000, 2002; CERRÓN PALOMINO 1987; ZIMMERMANN 1995).

No entanto, há duas diferentes perspectivas a respeito da influência das línguas indígenas no espanhol de América. Zimmermann (1995) afirma que há duas grandes tendências entre os hispanistas: uma que propõe que a variação na língua espanhola na América Latina se deve, especialmente, ao contato com as línguas indígenas, e que essa influência se encontra em todos os níveis da língua, embora afirmem que o nível mais permeável da língua é o léxico-semântico e o menos permeável o sintático; a outra perspectiva defende que a variedade da língua espanhola no Novo Mundo se deve, principalmente, às tensões internas da língua, o que se conhece como deriva linguística, afirmando que a influência das línguas 
indígenas americanas no espanhol não é mais do que uma série de empréstimos lexicais. Os estudos conduzidos por Arboleda Toro $(2000,2002)$ sobre o espanhol andino colombiano, variedade na que se encaixaria o espanhol de Aldana, seguem a primeira perspectiva. $\mathrm{O}$ autor aponta alguns fenômenos históricos relevantes para o surgimento da variedade do espanhol do sul da Colômbia e faz uma descrição de traços linguísticos presentes na grande área linguística em questão, filiando a variedade linguística da região à grande área linguística do espanhol andino falado nos Andes sul-americanos. No entanto, embora reconheça a pressão de alguns eventos históricos, os resultados dessas pressões são apresentados, por um lado, como empréstimos de línguas indígenas, principalmente do quéchua, e, por outro, como fenômenos vindos do espanhol ibérico que se desenvolveram na América.

O surgimento da variedade de espanhol específica de Aldana, neste trabalho, foi encarado a partir de outro ponto de vista - aquele proposto por Mufwene (2008) - que vê a mudança e a evolução linguísticas como o resultado das pressões que uma ecologia específica exerce sobre as línguas envolvidas em uma situação de contato, de maneira que traços de todas elas sejam ora adotados como a norma comum, ora eliminados na variedade emergente. Esses traços vindos de todas as línguas que estão em contato formam um banco de traços, a partir do qual as crianças escolhem alguns, no processo de aquisição da língua. Nesse processo - tanto aquele de criação do banco de traços quanto no de aquisição - o material vindo de cada língua sofre alterações e acomodações, e compõe o potencial inteiro da língua que irá emergir de cada ecologia de contato particular (MUFWENE 2008, p.183). Dessa perspectiva, não é possível falar dos efeitos do contato entre línguas como sendo meramente uma questão de empréstimos, como propõe Arboleda Toro $(2000,2002)$; a proposta de Mufwene (2008) não concebe que as línguas, numa situação de contato, imersas em condições históricas e sociais particulares e intensas, sejam sistemas isolados que somente se encontram em certos espaços, ou que emprestam alguns elementos umas das outras quando preferem ou precisam. ${ }^{1}$

\footnotetext{
${ }^{1}$ Esta dissertação não pretende trazer uma análise exaustiva sobre as condições de surgimento do espanhol falado em Aldana, por dois motivos: i) o objeto da pesquisa não é a variedade de espanhol de Aldana como um todo, nem sequer algum aspecto gramatical específico da região, e sim as mudanças de Ponto de Vista no caso específico das narrativas dos habitantes da Reserva; ii) não vai
} 
A análise histórica das condições do contato entre populações de falantes de diferentes línguas faz parte do que se considera o estudo da ecologia linguística. A ecologia linguística compreende tanto as condições sociohistóricas e econômicas das populações que entram em contato, quanto as características das línguas faladas por aqueles que interagem nessas condições. Das primeiras depende o prestígio que se atribui a cada língua na situação de contato, e a situação na qual se encontram os falantes da língua de menos prestígio na hora de enfrentar situações em que se impõe a língua de prestígio. Segundo Mufwene (2008, p.21), até os aspectos psicológicos da personalidade de cada falante determinam as escolhas linguísticas que ele fará em função do seu desejo de ser reconhecido em um ou outro nível socioeconômico, ou entorno social. Fazem parte dessas características sociohistóricas também as proporções demográficas de uns e outros na situação de contato, pois a quantidade de falantes de cada língua pode influir nas necessidades comunicativas de cada falante. Por exemplo, em uma situação de contato em que haja uma população indígena muito alta em comparação com uma população de colonizadores baixa, os indígenas vão comunicar-se muito mais entre si do que com os colonizadores, pelo simples fato de eles conviverem mais com outros indígenas do que com colonizadores. A informação demográfica será a que permitirá, em maior medida, desenhar o quadro da situação inicial do contato entre as línguas dos indígenas andinos e o espanhol na área atualmente ocupada por Aldana, especialmente por falta de informações de outra natureza no que se refere a esse contato inicial no século XVI.

O segundo grupo de fatores a ser levado em conta quando se analisa uma situação de contato é aquele que se refere às características das línguas que participam de um situação de contato específica. Isso porque, é a partir delas, que vai se construir o banco de traços que vai fornecer o material a partir do qual a nova língua ou variedade vai emergir. No caso específico deste estudo, as línguas que se encontravam na região quando da chegada dos espanhóis ao sul da atual Colômbia eram o pastás, o quillacinga e a língua dos abades, das

ser apresentada aqui uma descrição da gramática da língua, nem das suas diferenças com o espanhol ou com as línguas indígenas, ,das quais, de resto, não há registros. No entanto, uma aproximação, pelo menos geral, com a variedade de língua falada na região é necessária para mais bem localizar o contexto de surgimento das narrativas. 
quais falarei mais adiante. Além das línguas nativas do local, os colonizadores trouxeram consigo o espanhol, que para a época em que eles chegaram no sul da atual Colômbia já tinha sofrido um processo de contato intenso com as línguas mais austrais no continente. É importante também ressaltar que esses colonizadores europeus não falavam uma única variedade de espanhol, pois vinham de regiões diferentes da península ibérica. ${ }^{2}$

Alguns estudiosos colocam o quéchua também entre as línguas que se encontravam no local antes da conquista. No entanto a presença dessa língua na região que corresponde ao sul da atual Colômbia é um tema controverso. Arboleda Toro (2000) afirma que a onda expansiva do império incaico chegou até a margem norte do que hoje é o Departamento de Nariño, e que até hoje o espahol e o quéchua, que em território colombiano tem o nome de inga, coexistem na região sul do país (ARBOLEDA TORO 2000, p.93). Esses núcleos de língua inga, no entanto, se localizam nas zonas baixas dos Departamentos de Nariño e Cauca, e nos departamentos de Caquetá e Putumayo a leste da Cordilheira dos Andes, como mostra o Mapa 2. Nesse mapa o ponto marcado com vermelho é Aldana, os marcados com amarelo são os núcleos de língua inga na atualidade, segundo informações do Portal de Lenguas de Colombia. ${ }^{3} \mathrm{Na}$ área montanhosa de Nariño, onde se localiza Aldana, não há presença de língua inga, como pode ser visto no mapa. Todos os núcleos de língua inga se encontram nas zonas baixas, no mapa marcadas indicadas com a área verde. Cerrón Palomino afirma, por outro lado, que a chegada da língua dos incas aos territórios colombianos mencionados por Arboleda Toro só aconteceu durante a colônia, com a expansão do império espanhol nas Américas, pois essa língua teria sido utilizada como língua de comunicação com as novas etnias conquistadas pelos espanhóis. $\mathrm{O}$ autor explica que a emergência da língua inga na região se deve à presença, no norte dos Andes, de missionários e yanaconas falantes de quéchua (CERRÓN PALOMINO 1987, p.53). Para sabermos qual a relação do atual espanhol de Aldana com essas variantes ingas do quéchua seria necessário fazer uma pesquisa detalhada sobre os padrões migratórios desses indígenas que agora ocupam as zonas baixas dos Departamentos de Nariño, Cauca,

\footnotetext{
${ }^{2}$ Aquilo que se conhece hoje como língua espanhola não existia como tal no início da expansão imperialista ibérica. O território hoje ocupado pela Espanha se constituía, no século XV, de vários reinos onde se falavam línguas diferentes, que só havia pouco tempo tinham sido unificados.

${ }^{3}$ http://lenguasdecolombia.caroycuervo.gov.co/mapalenguas/ consultado em: 18/05/2016.
} 
Putumayo e Caquetá, assim como uma pesquisa sobre a língua inga e sua relação com o quéchua; no entanto, esse não é o propósito da pesquisa aqui apresentada.

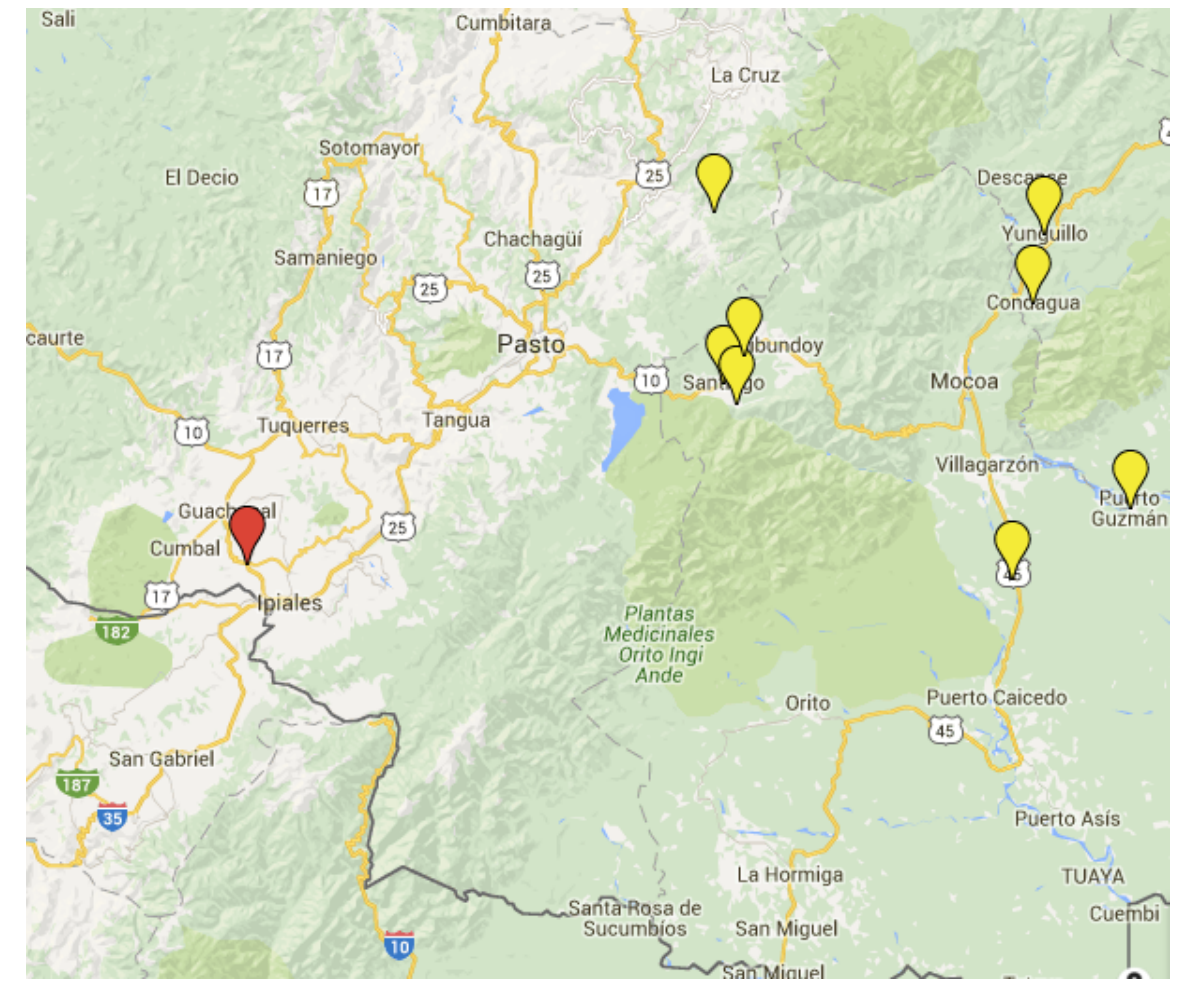

Mapa 2 Localização dos núcleos de língua inga atualmente na Colômbia. Informações adquiridas no Portal de Lenguas de Colômbia.

Sobre a presença ou não do quéchua na área específica de Aldana não se tem informação; no entanto, há informação sobre a expansão do império incaico no continente, que pode ajudar a esclarecer a questão. Segundo Cerrón Palomino (1987) a expansão do império incaico se deu em quatro grandes ondas expansivas. O Mapa 3 mostra as áreas conquistadas pelos incas em cada uma dessas fases de expansão. A primeira onda expansiva, indicada no mapa com o polígono amarelo, teve início em meados do século XV e se deu sob o comando de Pachacútec, que reinou de 1438 a 1471. Nessa primeira fase, o império conquistou as áreas do vale do Rio Titicaca ao sul de Cusco (marcação azul no Mapa 3) e toda a área da serra central peruana (CERRÓN PALOMINO 1987, p.49). A segunda onda expansiva, marcada com o polígono roxo no Mapa 3, esteve a cargo do filho de Pachacútec, Túpac Inca Yupanqui (?-1493), e começou paralelamente à primeira onda expansiva. Esta dominou os territórios da serra norte do Perú, até Quito, e dali seguiu pela 
costa equatoriana no sentido sul. Com a renúncia de Pachacútec ao trono em 1471, Túpac Inca Yupanqui assumiu o poder e organizou a conquista do sul, no Mapa 3 marcado com o polígono vermelho. Essa onda expansiva delimitou a margem sul do império, na atual cidade chilena de Constitución, e tomou, para os incas, o território da atual Bolívia, e parte do território ao norte da Argentina. Essa fase terminou com a morte de Túpac Inca Yupanqui por volta de 1493. A última onda expansiva foi comandada pelo filho de Túpac Inca Yupanqui, Huaina Capac. Esta fase, no mapa indicada pelo polígono verde, corresponde à expansão do império ao norte. Nela, o império anexou as zonas baixas ao nordeste do Perú e do Equador, e chegou até o Rio Ancasmayo, hoje Río Carchi, que marca a atual fronteira entre Equador e Colômbia. A partir daí, a campanha expansiva voltou pela costa do Equador no sentido sul (CERRÓN PALOMINO 1987, p.50). No ano da morte de Huaina Capac (ca. 1537) já havia rumores sobre a chegada de Pizarro às costas de Tumbes, no litoral norte do atual Perú.

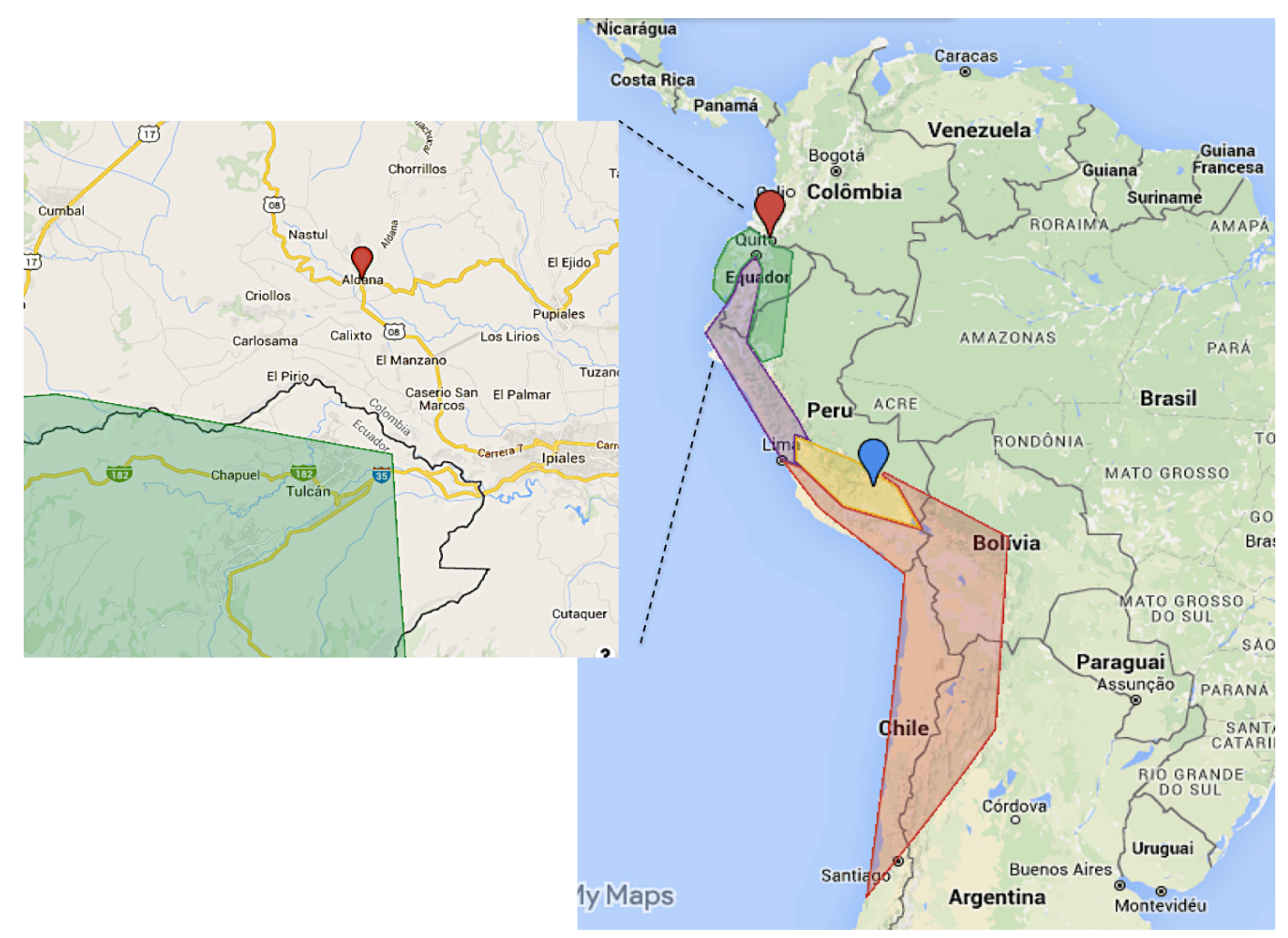

Mapa 3 Expansão do império incaico. Informações tomadas de Cerrón Palomino (1987). À direita se mostra a expansão do mapa que mostra a relação da área ocupada pelo império e Aldana, o município que interessa à pesquisa. 
O Mapa 3 também mostra com mais detalhe a área que interessa a esta pesquisa, na qual pode ser vista a relação da atual Aldana, marcada com o ponto vermelho, com a fronteira do que teria sido a área dominada pelo império incaico na última onda expansiva. A distância do centro do Município de Aldana até o Rio Carchi, ou seja o limite norte do império incaico, é de apenas 6 a $10 \mathrm{~km}$. Além disso, como pode ser visto no Mapa 4 a área ocupada pelos indígenas pastos, proposta por Calero (1997), ultrapassa o Rio Carchi ao sul, o que indica que ela se sobreporia ao limite norte do império incaico, proposto por Cerrón Palomino (1987). Baseada na informação obtida de Calero (1997) sobre a área ocupada pelos pastos, e na de Cerrón Palomino (1987) sobre a expansão do império incaico, e embora esse autor afirme que o quéchua na atual Colômbia veio só com a expansão do império espanhol nas Américas, vou assumir que, com a expansão do império dos incas, a língua quéchua alcançou o território dos pastos e fazia parte da ecologia de comunicação na região no século XVI.

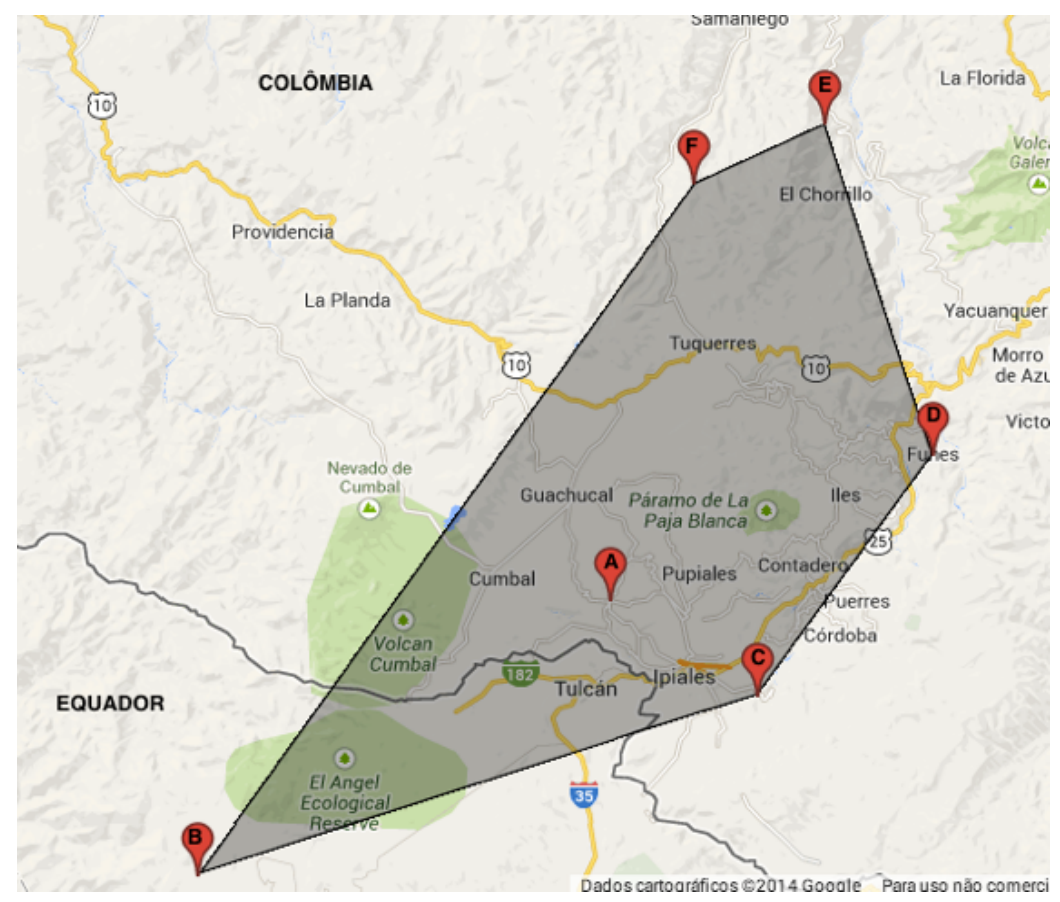

Mapa 4 Área proposta por Calero (1997) do território ocupado pelos indígenas pastos à chegada dos espanhóis ao norte dos Andes. (A) atual Município de Aldana; (B) Carchi, Equador: limite sul; (C) Yaramal, Colômbia: limite sudeste; (D) Funes, Colômbia: limite nordeste; (E) Ancuya, Colômbia: limite norte; (F) Yascual, Colômbia: limite noroeste; (-) Fronteira Colômbia-Equador. 
Temos então que antes da chegada dos espanhóis em 1535 ao território do atual Departamento de Nariño, a zona era povoada pelas etnias dos pastos, quillacingas e abades, e pode-se afirmar que havia também indígenas falantes de quéchua na área. Esses povos indígenas originários da zona habitavam a área há mais de sete séculos segundo pesquisas arqueológicas (CALERO 1997, p.xi) e no ano em que os conquistadores pisaram pela primeira vez o território ao norte dos Andes, sua população se calcula ao redor de 150.000 indivíduos. Organizavam-se em chefias, constituídas geralmente por grupos de parentesco, com um único líder a quem rendiam tributo. Eram povos agricultores que plantavam quinoa, batatas e outros tubérculos nas terras altas, e milho e algodão nas terras baixas. Os assentamentos dos pastos, por exemplo, se localizavam de 3.100 até 800 metros acima do nível do mar (CALERO 1997, p.35). Segundo Calero (1997), o aproveitamento de terras altas e baixas, e a consequente diversidade alimentícia, favoreceu o crescimento dessas populações e, em geral, uma situação de bem-estar até a chegada dos espanhóis.

Para este estudo é especialmente pertinente a situação dos indígenas pastos, pois atualmente, Aldana é a alocação da Reserva Indígena Pasto de Pastás, que se encontra localizada no ponto central do que foi a área de ocupação dessa etnia nos Andes colombianos (ver Mapa 4 acima) antes da conquista da América e durante a colônia. Seus habitantes se reconhecem como herdeiros dos indígenas pastos que povoaram o norte dos Andes durante séculos. No entanto, não é possível desligar o desenvolvimento da cultura pasto das culturas quillacinga e abad, pois as três etnias dividiram o espaço geográfico que compõe atualmente o Departamento de Nariño. Além disso, parece que estabeleceram durante esse tempo uma rede de intercâmbio de bens, como tecidos (trabalhados pelos pastos), alimentos e colares de cháquiras (miçangas), que segundo as informações históricas e arqueológicas funcionavam como um tipo de dinheiro usado no intercambio interétnico e, posteriormente, com os espanhóis (CALERO 1997, p.33). Além do contato entre as etnias originárias do território andino do atual Nariño, no fim do século XV houve uma influência do império incaico na área, por causa de sua última e já mencionada 
expansão liderada por Huayna Cápac (CALERO 1997, p.22). ${ }^{4}$ Contrariamente ao que se poderia pensar, o contato entre pastos, abades e quillacingas não se interrompeu com a chegada dos colonizadores, tendo inclusive aumentado por causa da estratégia colonial de realocação dos nativos para formar as encomiendas e as doctrinas, que serviam para os colonizadores terem uma melhor supervisão sobre a população indígena (CALERO 1997, 66). O funcionamento dessas duas modalidades de governo vai ser explicado em mais detalhe adiante.

Sobre a língua dos pastos sabemos pouco, pois está extinta e fora as pouquíssimas referências às línguas indígenas nos registros dos colonizadores não se tem mais informação sobre ela. No entanto, algumas classificações têm sido feitas com base nessas descrições. Hernández de Alba (1946, p.922) oferece uma classificação da língua dos pastos, colocando-a como parte do grupo das línguas tucano dentro da família linguística chibcha. Já Rodríguez Rosales (2001, p.3) a classifica como uma língua similar à cuayquer da família chibcha, do subgrupo ocidental. No que os dois autores e Ortiz (1946, p.914) parecem concordar é que a língua dos pastos foi falada até meados do século XVIII. Segundo Rodríguez Rosales (2001), o que restou dela são alguns topônimos e antropônimos. Entretanto, essa é uma posição discutível, pois parte de uma visão de língua em que o contato não repercute na mudança linguística e tem como único resultado o desaparecimento de uma língua (a dos pastos) e a preponderância de outra (o espanhol), como se as línguas não tivessem nenhuma permeabilidade, o que conflita com a visão de língua proposta aqui.

Se a língua dos pastos esteve em contato com o espanhol por dois séculos, é preciso considerar, seguindo Mufwene (2008), que naquilo que consideramos como espanhol de Aldana, ou espanhol andino colombiano, há traços linguísticos daquelas línguas vernáculas faladas na região. Esses traços não são vistos aqui como elementos das línguas indígenas que conseguiram entrar no sistema do espanhol nos Andes, mas como elementos

\footnotetext{
${ }^{4}$ Essas informações coincidem com as obtidas de Cerrón Palomino (1987). Huayna Capac é a ortografia pela que optou Calero (1997), enquanto que no texto de Cerrón Palomino (1987) encontramos o nome grafado como Huaina Capac.
} 
fundamentais da formação dessa variedade de espanhol que encontramos na zona atualmente, pois o contato é o detonador da mudança linguística. Na proposta de Mufwene (2008), o contato de línguas se dá no nível idioletal, e são as condições ecológicas do contato dos grupos de falantes as que determinam quais traços escolhidos por cada falante em cada interação entram e se estabilizam no sistema da língua.

Como dito anteriormente, o contato entre as línguas espanhola e indígenas na região se deu dentro da estrutura política e econômica estabelecida pelas encomiendas e as doctrinas, dois tipos de assentamento impostos pelos espanhóis no século XVI. Os principais propósitos dessas estruturas de controle eram, no caso das encomiendas, recolher tributos dos indígenas do povoado, além de explorar a terra e, especialmente na região oeste do atual Nariño, explorar as minas de ouro. Já nas doctrinas, o principal objetivo era catequizar os indígenas além de exercer um certo controle sobre os encomenderos (administradores das encomiendas) e, a princípio, velar pela integridade dos indígenas.

A encomienda chegou em Nariño com a fundação do vilarejo de Villaviciosa de la Concepción de Pasto. Essa instituição já tinha mais de 50 anos na América espanhola e tinha sofrido várias mudanças nesse tempo. Quando ela foi instaurada nos Andes colombianos, os nativos já não eram mais tidos como escravos (como havia acontecido no Caribe), mas como vassalos livres do rei (CALERO 1997, p.55). Os enconmenderos, ou seja os espanhóis administradores das encomendas, se instalaram nas Américas como uma espécie de aristocracia com vastíssimo poder econômico. Houve uma grande oposição à instituição das encomiendas por parte de alguns espanhóis, principalmente de padres, dentre eles Bartolomé De Las Casas, Bispo da Guatemala, por causa dos maus tratos à população indígena e de sua rápida diminuição. Essa oposição levou à promulgação, em 1542, das Novas Leis de Carlos V, que procuravam controlar a ação dos encomenderos no continente. Mas o poder deles era maior, e entre 1545 e 1546 as Novas Leis foram reformadas para favorecê-los. No entanto, regularam a quantidade de tributo exigida aos indígenas (CALERO 1997, p.55). Porém, a Espanha tinha pouco controle sobre as terras conquistadas e, especialmente pelo isolamento geográfico do norte dos Andes, os encomenderos conseguiram ignorar e descumprir as Novas Leis; por causa disso e pela 
pressão do Bispo de Popayán, a Audiencia de Santafé de Bogotá, enviou em 1558, o primeiro juiz para fazer uma inspeção das encomiendas da Província de Popayán. É graças a essa e às subsequentes visitas de inspeção que se tem informação sobre a quantidade de indígenas vivendo naquela zona durante o século XVI.

A Tabela 1 apresenta a relação de indígenas na Província de Popayán registrados pelos visitantes durante o século XVI e a quantidade de espanhóis registrados vindos aos Vicereinados de Nova Granada, Peru e à Gobernación de Quito durante a mesma época. As informações sobre a população indígena foram extraídas de Calero (1997) e sobre os espanhóis, de Boyd-Bowman (1976). Foram escolhidas só as informações sobre os Vicereinados de Nova Granada e Peru, e a Gobernación de Quito, pois essa era a zona de influência do norte dos Andes durante o século XVI. Villaviciosa de la Concepción de Pasto foi fundada por ordem do Governador de Quito em 1537, mas o seu estabelecimento como vila foi feito pelo Capitão Francisco de Aldana em 1539, seguindo ordens de Francisco Pizzaro a partir do Vice-reino do Peru (Calero 1997). No entanto, quem assumiu seu governo foi Quito. Já em 1540, a cidade e seus arredores passaram a ser administrada pela Gobernación de Popayán, que fazia parte do Vice-reino de Nova Granada. 


\begin{tabular}{|c|c|c|c|c|c|}
\hline \multicolumn{6}{|c|}{ Relação de indígenas e espanhóis na zona de influência do atual Nariño } \\
\hline & Visitas & Indígenas & $\begin{array}{l}\text { Espanhóis chegados à } \\
\text { Nueva Granada }\end{array}$ & $\begin{array}{l}\text { Espanhóis } \\
\text { chegados a Peru }\end{array}$ & $\begin{array}{l}\text { Espanhóis } \\
\text { chegados a Quito }\end{array}$ \\
\hline 1493-1519 & & & $\begin{array}{c}\mathrm{SD}^{* *} \\
\end{array}$ & 92 & $\begin{array}{ll}\mathrm{SD} \\
\end{array}$ \\
\hline $1520-1539$ & & & 906 & 1.342 & SD \\
\hline $1540-1559$ & $\begin{array}{l}1558 \text { Visitador } \\
\text { López }\end{array}$ & 21.767 & 892 & 3.248 & SD \\
\hline $1560-1579$ & \begin{tabular}{|l}
1570 Visitador \\
Valverde
\end{tabular} & 12.614 & 1.586 & 3.882 & 291 \\
\hline & $\begin{array}{l}1580 \text { Visitador } \\
\text { Escobar }\end{array}$ & 8.000 & & & \\
\hline & $\begin{array}{l}1582 \text { Visitador } \\
\text { Centellas }\end{array}$ & $4.893^{*}$ & & & \\
\hline $1580-1600$ & $\begin{array}{l}1590 \text { Visitador } \\
\text { Ortega }\end{array}$ & 7.357 & 454 & 3.295 & 208 \\
\hline
\end{tabular}

Tabela 1 Relação de indígenas e espanhóis no século XVI na zona de influência do atual Departamento de Nariño. As informações das colunas Visitas e Indígenas são de Calero (1997) e as das colunas restantes de Boyd-Bowman (1976); (*) os dados da visita do Visitador Centellas estão incompletos; $(* *)$ SD: sem dados.

Os dados na tabela mostram como, ao longo do século XVI, num período de cerca de 80 anos, a população indígena que foi recenseada em Nariño diminuiu em dois terços aproximadamente. Segundo Calero (1997, p.58) um dos motivos que mais dizimou a população indígena foram as doenças introduzidas pelos espanhóis, além da fuga de indígenas das encomiendas para locais ainda mais afastados, dentre eles a selva amazônica, o que foi maior estratégia de luta contra a imposição da coroa espanhola.

Em 1558, data da visita de Tomás López à Província de Popayán, a população indígena era de 21.767 indígenas, enquanto que a população espanhola do Peru, Nova Granada e Quito combinada era de cerca de 7.000 pessoas. Naturalmente não é possível pensar que foi um encontro de 21.000 indígenas e 7.000 espanhóis, pois os dados apresentados não se referem à mesma zona, mas é possível ver, com essa comparação, quão maior era a população indígena em relação à população espanhola na América do Sul. Em 1582, só na Província de Popayán, para cada encomendero havia de 4 a 200 indígenas que pagavam tributo (CALERO 1997, p.150). No entanto, podemos ver que conforme a população indígena 
diminuía, a população espanhola aumentava. Nas últimas duas décadas de 1500, havia uma população espanhola de aproximadamente 16.000 pessoas nos dois Vice-reinos e na Gobernación de Quito, só contando os que chegaram à América, pois não se tem dados sobre os nascimentos $;^{5}$ a população indígena da Província de Popayán tinha chegado a 7.000 pessoas no mesmo período de tempo.

Os dados demográficos permitem colocar algumas perguntas a respeito das condições do contato entre os colonizadores e os indígenas. Calero (1997, p.66) afirma que muitos dos indígenas optaram por aprender espanhol como uma das formas de não opor resistência à cultura espanhola. No entanto, se no começo a população indígena superava tanto a espanhola, qual a necessidade comunicativa dos indígenas de aprender espanhol? Provavelmente eles se comunicavam muito mais entre si do que com o encomendero, por exemplo, especialmente com proporções de espanhóis e indígenas nas encomiendas de 1 para 58. Outra pergunta importante é como se dava essa aquisição do espanhol, e que variedade de espanhol eles aprenderam?

Provavelmente, a missão do ensino ou imposição do espanhol era parte das atividades que as missões católicas desenvolviam no Novo Mundo. Oficialmente, o trabalho de catequização e tradução da catequese e do confessionário era deixada a cargo dos padres das doctrinas. Doctrinas eram uma forma de controle ideológico e econômico, pois facilitavam a conversão dos indígenas à religião católica, além de organizar a coleta de tributo do trabalho dos nativos. Em cada um desses povoados, produtos da realocação, havia um padre e se construía uma igreja. Na atual zona andina colombiana, o Visitador García de Valverde (visita de 1570-71) estabeleceu dezesseis doctrinas com populações indígenas que oscilavam entre as 155 e 1.000 famílias. O padre recebia um salário anual e era obrigado a estabelecer sua residência na doctrina e não nos vilarejos espanhóis (CALERO 1997, p.67), o que indica que havia uma separação entre povoados majoritariamente indígenas e outros majoritariamente espanhóis. Calero (1997, p.67) afirma que o propósito principal de obrigar os padres a morar nos vilarejos indígenas era o de

\footnotetext{
${ }^{5}$ Segundo Boyd-Bowman (1976) a partir de 1540 já havia mulheres e crianças viajando para o Novo Mundo para se reunir com os seus maridos e pais, ou para trabalhar no serviço doméstico.
} 
fortalecer a moral e as práticas cristãs na comunidade. Não fica claro qual era o objetivo dessa segregação entre vilarejos espanhóis e indígenas, mas podemos especular, seguindo a proposta de Mufwene (2008, p.181) que a separação de povoados fez com que os nativos tivessem pouco e esporádico contato com os espanhóis em um primeiro momento o que fez com que eles desenvolvessem formas próprias de falar o espanhol que traziam muitos elementos de suas línguas nativas.

Os doctrineros chegaram a ter, entre suas funções, as de administradores da doctrina além de juízes, pelo que tinham o dever de resolver conflitos entre indígenas e entre indígenas e espanhóis, e o poder para castigar os nativos quando considerassem apropriado. Para assisti-los nessas tarefas, os padres mantinham na paróquia um alguacil lengua e um alguacil general, índios ladinos, ou seja, índios que tinham aprendido espanhol. A função do primeiro era a de fazer traduções das línguas indígenas para o espanhol, e as do segundo incluíam as de atuar como supervisor e detetive do doctrinero (CALERO 1997, p.68). Parece então que a grande maioria da população não falava espanhol e que a forma de comunicação nas doctrinas era feita por meio de intérpretes.

As encomiendas e as doctrinas foram os sistemas econômicos impostos e mantidos da Conquista até o fim da Colônia, o que indica que, por mais ou menos dois séculos, as relações econômicas e sociais se deram nos termos expostos até aqui. Segundo Narváez Ramíres (2006), até finais do século XVIII, a Gobernación de Popayán, da qual fazia parte o atual território de Aldana, foi bastante pouco desenvolvida no que toca à construção de vias de acesso dentro do território e para a comunicação com outras Gobernaciones. Segundo o autor, até o fim da colônia só havia uma via principal na região, que fazia a ligação de Quito (no Vice-reino do Equador) com Popayán; o resto das vias eram ainda caminhos de terra herdados do comércio indígena de antes da chegada dos espanhóis (NARVÁEZ RAMÍRES 2006, p. 21). Um desses era o caminho que ligava o Sudoeste de Pasto a Ipiales e Túquerres, na fronteira com o Equador. Provavelmente, esse caminho era aquele que os pastos, quillacingas e abades já utilizavam para o comércio interétnico e que se manteve para o comércio de alimentos, mantas e têxteis, produzidos na região, e para a entrada do arroz vindo de Guayaquil, no Equador. Parece acertado afirmar que, durante 
esse período, houve mais contato da população do sul da Colômbia com as populações do Equador, do que com aquelas que pertenciam aos territórios ao norte, não só pelas difíceis condições de acesso ao sul, mas também pelas relações comerciais estabelecidas entre Popayán, Pasto e Quito.

Com a chegada do século XIX, chegaram também as Guerras de Independência, durante as quais o território do atual Nariño foi decididamente favorável a se manter súdito do rei, opondo-se à maré de movimentos independentistas vindos tanto do norte, da província de Popayán e da de Santa Fé de Bogotá, quanto do sul, da Gobernación de Quito. Durante esse período o isolamento da região se intensificou, pois muitas das vias de acesso foram fechadas, e o comércio se enfraqueceu notadamente, pois a posição política adotada pelos nariñenses fez com que muitas das suas antigas relações comerciais se quebrassem. Sobre esse período há pouca informação demográfica, mas Narváez Ramíres (2006, p.26) oferece um dado interessante para a região de Ipiales (fronteira sul da atual Colômbia com o Equador). Segundo os dados do autor, em 1809, a população de Ipiales se distribuía da maneira mostrada na Tabela 2.

\begin{tabular}{|l|l|}
\hline População & Quantidade total \\
\hline Índios & 12.300 \\
\hline Pardos e outros & 746 \\
\hline Montanheses $^{6}$ & 7.700 \\
\hline Nobres & 2.600 \\
\hline
\end{tabular}

Tabela 2 Tabela demográfica da região de Ipiales para 1809, tomada de Narváez Ramíres (2006, p.26).

Esses dados são interessantes, pois, se comparados com os dados da Tabela 1, mostram que em duzentos anos a população indígena passou de aproximadamente 7.000 indivíduos para 12.000 e, em 1809, já se tinha uma população considerável de mestiços, que superava inclusive a de nobres. Essa população mestiça indica uma miscigenação que permitiria

\footnotetext{
${ }^{6}$ Os montañeses eram mestiços que se autodenominavam dessa maneira por serem habitantes de áreas rurais que não reconheciam como tendo ascendência ameríndia. Eles optaram por um nome diferente do de mestiço para se diferenciar daqueles aos quais era reconhecida uma ascendência indígena (IBARRA DÁVILA 2002, p.109).
} 
assumir que a predominância do espanhol na área do estudo não se deve somente a uma eliminação da população indígena, mas também a um processo de perda da língua indígena por parte de filhos de indígenas com brancos que quiçá nem aprenderam a língua indígena por essa ter pouco ou nenhum prestígio. Se o que afirmam Hernández de Alba (1946), Ortiz (1946) e Rodríguez Rosales (2001) for acertado, no ano de 1809 - — ano de que datam as informações demográficas da Tabela 2 - a língua dos pastos não era mais falada há aproximadamente meio século.

A história da região no século XIX e nos primeiros trinta anos do século XX não mudou consideravelmente no que toca ao isolamento geográfico, especialmente em relação ao centro do país. Após ter sido derrotado na Guerra de Independência, e depois de sobreviver às Guerras de Separação das Repúblicas da Colômbia e do Equador, o Departamento de Nariño continuou com uma infraestrutura viária precária, e a maior rota de comércio continuou sendo com Guayaquil ao sul. Só nos anos trinta do século XX, com a necessidade de criar uma rota do centro do país para o sul, pela necessidade de abastecimento na guerra contra o Perú, construiu-se a primeira (e única) grande rodovia que uniria o centro político, econômino e geográfico do país com o Departamento de Nariño.

Embora descrever detalhadamente as condições em que se deu o contato entre espanhol e as línguas indígenas no território da atual Aldana não seja o objetivo principal dessa pesquisa, e embora faltem ainda muitos dados que possam ilustrar como se deu o relacionamento constante entre indivíduos na região, há alguns padrões relevantes no que foi descrito acima, e que podem dar indícios sobre o desenvolvimento do espanhol na região.

O século XVI, na zona montanhosa do Departamento de Nariño, caracterizou-se por um forte multilinguismo. Além do espanhol vindo da península ibérica, havia no local as línguas de três etnias (pastos, quillacingas e abades) que já se encontravam em permanente situação de contato, por causa das redes de intercâmbio estabelecidas entre elas. Além disso, havia também algum dialeto do quéchua, mesmo que presente há pouco tempo ou só esporadicamente na região. Além disso, o espanhol vindo da Europa era também variado, e como os conquistadores que chegaram na região já estavam há vários anos dominando a 
parte mais austral do continente, suas variantes já deviam ter sido modificadas em alguma medida pelo contato com outros povos ameríndios. Provavelmente foi só depois do século XVI que o espanhol se tornou a língua majoritária, especialmente pelo esforço e presença prolongados das doctrinas e encomiendas na região.

Um dos motivos possíveis para a expansão do espanhol pode ter sido a rápida diminuição na população indígena. Embora a população indígena tenha superado sempre a de brancos, e inclusive do fim do século XVI para começo do XIX tenha aumentado, a população espanhola cresceu rapidamente ao longo desses dois séculos, e no, mesmo período de tempo, a população indígena das montanhas de Nariño diminuiu até aproximadamente a metade do seu tamanho. Pode-se afirmar que no começo do século XVI a necessidade dos indígenas de aprender espanhol era muito baixa, pois provavelmente se comunicavam muito mais entre si do que com os colonizadores, mas, conforme aumentava a população e o poder espanhol e diminuía a população indígena, as necessidades comunicativas mudaram.

Uma constante na região parece ser o isolamento geográfico que durou até o século XX. É possível inferir que houve poucas interferências externas durante esses quatro séculos, a não ser pela troca comercial com Guayaquil e a fronteira das Colômbia e Equador de hoje. ${ }^{7}$ Esse isolamento pode ter influenciado também o resultado da língua que hoje se fala na região, e muitas das características da língua dos pastos atualmente podem se dever a ele.

\footnotetext{
${ }^{7}$ Seria interessante indagar na possibilidade de que o desaparecimento das línguas nativas na região de Aldana se deva à força que o quéchua teve no Equador durante séculos, e que essa presença tão forte de outra língua majoritária tenha facilitado o enfraquecimento das línguas originárias da região, especialmente em se tratando de comunidades que mantiveram por séculos uma forte relação comercial com o sul. Tal vez esse enfraquecimento devido a presença do quéchua tenha facilitado a entrada do espanhol na região e por isso hoje não se falam mais línguas indígenas em Aldana. Por questões de tempo e foco de pesquisa não aprofundei mais na questão do multilinguismo no norte do Equador, mas não posso ficar sem indicar a possibilidade de pesquisa para o futuro.
} 


\subsection{Manuel Erira}

Manuel Erira é o indígena pasto entrevistado na gravação que transcrevi para esta pequisa. $\mathrm{Na}$ entrevista, como foi mencionado anteriormente, três antropólogos, dentre eles Valentina Arango Villalón e um outro indígena entrevistam Manuel Erira e lhe perguntam sobre o seu conhecimento de mitos, sobre o cuidado das plantas, sobre o tempo e sobre a situação política da reserva e do Cabildo, a entidade pública que se encarrega de representar a comunidade indígena frente ao Estado, além de organizar a comunidade em torno as atividades exigidas na lei

Na etnografía de Arango Villalón (2012) não há muita informação sobre a vida de Manuel Erira, sua idade, sua história de vida, suas relações familiares, etc. No entanto, sabemos pela informação da etnografía que Don Manuel Erira foi Gobernador Suplente del Cabildo de Pastás. ${ }^{8}$ O Gobernador do Cabildo, além de todos os seus membros, são escolhidos pela comunidade indígena. Ter sido escolhido para esse cargo público permite afirmar que Manuel Erira é uma pessoa cuja autoridade em temas políticos e étnicos é reconhecida pelos outros habitantes da Reserva. Talvez por isso também os antropólogos o tenham entrevistado, buscando tratar tanto sobre assuntos que têm a ver com ancestralidade, como sobre aqueles relativos à organização política e às perspectivas da Reserva e da instituição do Cabildo.

$\mathrm{Na}$ entrevista transcrita para esta pesquisa para é possível perceber que Manuel Erira conhece tanto a história da região, quanto as mitologias e o tratamento tradicional da terra. Também chama a atenção a constante referência que ele faz ao conhecimento que tinham os mais velhos, as histórias que eles contavam e o conhecimento ancestral.

\footnotetext{
${ }^{8}$ O Ministério del Interior da Colômbia define um Cabildo da seguinte maneira: "Es una entidad pública especial, cuyos integrantes son miembros de una comunidad indígena, elegidos y reconocidos por ésta, con una organización sociopolítica tradicional, cuya función es representar legalmente a la comunidad, ejercer la autoridad y realizar las actividades que le atribuyen las leyes, sus usos, costumbres y el reglamento interno de cada comunidad." (http://www.mininterior.gov.co/content/cabildo-indigena)
} 
Neste capítulo descrevi a localização da Reserva Indígena Pasto de Pastás em Aldana, no Departamento de Nariño ao sul da Colômbia, perto da fronteira com o Equador. Descrevi os modos de vida dos seus habitantes e suas práticas de criação de gado e cui e de plantação de hortaliças. Descrevi, além disso, as condições em que essas narrativas emergiram: uma entrevista etnográfica feita por três estudantes de antropologia da Universidade Nacional da Colômbia a Manuel Erira, quem é uma pessoa que cujo conhecimento sobre os assuntos dos pastos é reconhecido na comunidade. Também descrevi as condições ecológicas (MUFWENE 2008) da emergência da variedade de espanhol falada em Aldana. O século $\mathrm{XVI}$, no qual os conquistadores espanhóis pisaram por primeira vez no território em que se localiza a atual Aldana, esteve marcado por um forte multilinguismo: na área coexistiam as línguas pastás, abad, quillacinga e quéchua, e a elas se somou o espanhol, que para então já tinha tido contato com outras línguas na América do Sul e antes ainda na Península Ibérica e nos navios nas viagens que trouxeram a conquista à América. Essa descrição foi importante para a pesquisa, pois a contextualização de onde e em que condições foram contadas essas histórias ajuda na melhor compreensão seu conteúdo e a sua emergência. 


\section{Narrativa}

O objeto da presente pesquisa são duas narrativas sobre mitologia indígena que Manuel Erira contou para os seus entrevistadores em Aldana em 2011. Neste capítulo exponho o que entendo por narrativa e as implicações que a narrativa tem na identidade individual e cultural das pessoas. Isso é relevante, pois em se tratando de uma pesquisa sobre ponto de vista em narrativas indígenas, a relação que as pessoas estabelecem com os fatos narrados e com o próprio ato de narrar podem nos ajudar a entender o significado das narrativas e o posicionamento do narrador perante os fatos.

Nesta pesquisa, seguindo a proposta de Genette (1980), entendo como narrativa o discurso oral ou escrito que conta uma série de eventos reais ou ficcionais. As características desses eventos reais ou ficcionais, tais como sequencialidade ou a relação com os supostos eventos realmente acontecidos, eu vou chamar de história, seguindo ainda a proposta de Genette (1980). Alguns trabalhos sobre narrativa, mais especificamente sobre figura e fundo narrativo (LABOV E WALETZKY 1967; TENUTA 2006), têm se debruçado sobre a relação que a forma da narrativa tem com os eventos descritos na história, e para isso têm dedicado sua análise a narrativas de experiência pessoal. Nesta pesquisa, no entanto, o fato de os eventos da história terem sido ou não vividos pessoalmente pelo narrador é irrelevante, pois não se trata aqui de uma comparação entre os eventos supostamente acontecidos e sua sequencialidade e a forma de narrar do narrador.

Além de um interesse linguístico pelas narrativas, e por se tratar da análise de narrativas indígenas, alguns outras características da narrativa são interessantes e se fazem necessárias para enquadrar essa pesquisa. As propostas de Bruner (2002; 2004) e Klapproth (2004) exploradas a continuação ampliam a noção de narrativa e sua função na construção de identidades individuais e grupais.

Bruner $(2002 ; 2004)$ analisa a relação da narrativa com a identidade, tanto individual quanto grupal. O autor propõe que a narrativa é o meio fundamental pelo qual construímos uma identidade, e que, por sua vez, a identidade não é senão um conjunto de narrativas que 
negociam nossas expectativas com o nosso passado, localizadas em uma cultura específica. Já Klapproth (2004) descreve a narrativa como um componente vital para a criação e negociação de uma cultura com o seu mundo (p.4). Os dois autores concordam que a capacidade narrativa é a forma privilegiada pela qual transformamos a experiência em língua e que a maneira de fazermos isso é determinada pela nossa cultura.

No que diz respeito à estrutura da narrativa, Bruner afirma que uma narrativa precisa de três elementos principais para se construir como tal. O primeiro deles é "o nosso irresistível sentido de continuidade ao longo do tempo e do espaço" (BRUNER 2002, p.75). Para Ricoeur (1988), esse 'irresistível sentido’ que nos caracteriza como espécie é a capacidade de reconhecer uma mesmidade ao longo do tempo, ou seja, a capacidade de construir um selbst a partir da narrativa. ${ }^{9}$ A capacidade de unir vários eventos e identidades separadas no tempo e reconhecer todos eles como fazendo parte da mesma história só nos é permitido por meio da narrativa. E isso não se expressa só no nível individual (por exemplo, que eu possa dizer que eu aos quatro anos e eu hoje somos o mesmo eu), mas no nível grupal, no caso em que contamos mitos, lendas, histórias de família para nos reconhecer como a prole dos nossos antepassados.

Para Bruner, o tempo também é determinante nas narrativas porque é a partir dele que constantemente negociamos nossas expectativas, ou seja, contrastamos o que foi e o que poderia ser: o estado conhecido das coisas e a possibilidade da mudança. Nesse ato de equilibrista, surge o segundo elemento constitutivo da narrativa, a peripéteia, ou seja, o fato inesperado que traz o desequilíbrio. Segundo Bruner, "para que exista um relato, alguma coisa inesperada deve acontecer - de outro modo, não há o que contar" (BRUNER 2002, p.25). Essa perspectiva é compatível com a da maioria das propostas da análise de narrativas (ver, por exemplo, Tenuta 2006, p.48), mas como Klapproth propõe, a peripetéia, como entendida por Bruner, não é um conceito que possa ser aplicável a partir

\footnotetext{
${ }^{9}$ O termo selbst vem do alemão e quer dizer si mesmo. Ricoeur (1988) usa esse termo em oposição ao termo gleich (igual, o mesmo) para expor a sua ideia de que, por meio de narrativas, conseguimos construir uma ideia de nós mesmos (selbst) a partir de eventos isolados e identidades distintas ao longo da nossa vida. Construímos narrativas para passar o fio condutor entre estágios da nossa vida que nada têm de igual (gleich) uns com os outros. Segundo o autor, a narrativa é o meio de reconhecermos uma identidade entre eventos esparsos e desligados.
} 
de uma perspectiva translinguística e transcultural. A autora afirma que mais do que um evento inesperado ou a extraordinariedade do evento narrado, aquilo de que uma narrativa precisa é de um evento que seja de interesse cultural para a comunidade interpretativa (KLAPPROTH 2004, p.389).

O terceiro aspecto determinante para a construção de narrativas é a relação causal, que é a ação de tecer as experiências que constituem a nossa narrativa pessoal ou grupal, ligando-as umas às outras. Na pesquisa de Klapproth, essa relação causal tem a ver com o que a autora chama 'estruturas de coerência' cujo papel é o de facilitar a compreensão e promover a resposta estética no(s) interlocutor(es) (KLAPPROTH 2004, p. 390). A teoria de espaços mentais - modelo teórico escolhido para a análise de narrativas feitas nesta dissertação permite ver a dinamicidade dessa estruturação causal dentro das narrativas, pois fornece elementos para identificar diferentes aspectos que mantêm a coesão da história (identificação de participantes, relações temporais, e a estrutura macro da narrativa).

Segundo Bruner (2004, p.694) a construção das narrativas é dependente de convenções culturais e do uso da linguagem, e reflete as teorias predominantes na cultura sobre 'vidas possíveis' e 'mundos possíveis' Essa afirmação traz a pergunta de se é a linguagem que cria o mundo ou o mundo que determina a forma da linguagem. Segundo o autor, a narrativa é uma via de mão dupla. As narrativas oferecem modelos do mundo (BRUNER 2002, p.34); no entanto, inclusive nas narrativas mais fantásticas, esperamos que haja um reconhecimento da realidade. Esse processo é dinâmico e não faz muito sentido perguntar quem veio primeiro, o ovo ou a narrativa; o melhor é entender como construímos nossa noção do que seja real a partir do conjunto de narrativas às quais somos expostos, e como construímos nossas narrativas a partir do que consideramos real; a noção de realidade e a produção de narrativas são processos que se alimentam reciprocamente. Nesse jogo, a cultura é então, nas palavras de Bruner, "autora e editora do previsível” (BRUNER 2002, p.25), pois é ela que determina as histórias possíveis. Quando contamos uma história, ela deve estar em consonância com as histórias de nossos pares; de nada vale uma história que os outros não consigam identificar. Se as regras do narrar fossem independentes da cultura 
e completamente arbitrárias, a situação seria de mútua incompreensão (BRUNER 2004, p.699).

Esse papel determinante da cultura na produção de narrativas permite afirmar, então, que o estudo das mesmas nos fornece um acesso à visão que as pessoas ou os grupos de pessoas têm das experiências que vivem. De alguma forma, as narrativas são uma janela à compreensão que um grupo de pessoas tem do seu entorno, da sua história e das suas ações. Klapproth diz: "quando começamos a escutar as histórias dos outros temos garantida uma espiada do mundo deles" (2004, p.405), pois cada povo cria, a partir das narrativas, um mundo que possa habitar e no qual possa se reconhecer nos outros. ${ }^{10} \mathrm{~A}$ análise das narrativas em espanhol andino, produzidas no município de Aldana, poderá oferecer uma janela às noções culturais relevantes para o grupo em questão.

Este capítulo apresentou o que vou entender por narrativa seguindo a proposta de Genette (1980) e dscutiu as propostas de Bruner (2002; 2004) de construção de identidade individual e grupal por meio das narrativas. Além disso apresentou as conclusões de Klapproth (2004) a respeito do que significa analisar narrativas indígenas e de como essas narrativas permitiriam ao pesquisador uma visão ao menos parcial da visão de mundo dos contadores das histórias analisadas. A seguir, apresento as duas narrativas de Manuel Erira, que são o material de análise desta pesquisa.

\footnotetext{
10 "when we start listening to the others' stories we are granted a glimpse into their world"
} (KLAPPROTH 2004, p.405). Atradução é minha. 


\section{As narrativas}

Este capítulo apresenta as duas narrativas que serão o objeto de análise desta pesquisa, e que surgiram no contexto de uma entrevista feita a Manuel Erira por três antropólogos e um conterrâneo. Essas narrativas emergiram na fala de Manuel Erira em momentos específicos da entrevista como um recurso explicativo ao ser questionado sobre alguns pontos de interesse para a comunidade e para os entrevistadores. A primeira delas surgiu em uma conversa sobre espíritos que aparecem na comunidade. A segunda, quando Manuel foi questionado sobre os ancestrais da comunidade. ${ }^{11}$

O formato em que elas são apresentadas é o resultado da aplicação do modelo de análise e edição de narrativas proposto por Hymes (1994). O autor afirma que a forma das narrativas orais participa da criação de significado das mesmas, e sendo esta uma pesquisa que se enquadra dentro da semântica cognitiva, a exploração dessas estruturas é relevante, pois permite uma melhor compreensão de como o falante estruturou a informação. A questão da distribuição da informação é especialmente relevante para a Teoria de Espaços Mentais, que será utilizada para fazer a análise das narrativas, pois esta propõe que a construção de significado se relaciona com a distribuição de informação no nível cognitivo (TENUTA \& LEPESQUEUR 2014).

A análise da forma das narrativas resultou no reconhecimento das seguintes unidades: (i.) episódios, marcados com números romanos (I; II; III; etc.); (ii.) estrofes, marcadas com letras maiúsculas (A; B; C; etc.); e linhas que compõem as estrofes e estão numeradas $(1 ; 2$; 3 ; 4; etc.) para facilitar a referência quando forem retomadas no capítulo 6. Essas unidades vão ser explicitadas mais adiante. As falas que aparecem em negrito não fazem parte da narrativa, mas são as perguntas que as suscitaram e que foram feitas por algum dos entrevistadores. Foram incluídas para facilitar a contextualização da emergência das narrativas, e sua compreensão e interpretação na análise.

${ }^{11}$ As narrativas serão apresentadas em espanhol. Comentários em português sobre o que significariam alguns trechos serão incluídos no texto. A transcrição da gravação inteira se encontra no Anexo. 
A identificação da unidade mínima nas narrativas, ou seja as linhas, foi feita a partir do conceito de unidade entoacional de Chafe (1994), e facilitou a primeira escolha em termos do que seria identificar as unidades nas narrativas. ${ }^{12}$ As unidades entoacionais coincidem com o que Hymes (1994) chama de linha nas suas análises de narrativas orais, no sentido de que ambas são unidades delimitadas por contornos entoacionais ${ }^{13} \mathrm{~A}$ identificação dessas unidades entoacionais ou linhas é muito importante para a análise de narrativas orais, pois nelas, diferentemente do que acontece na épica e em outros tipos de poesia, a restrição não se dá em termos de métrica, mas em termos da relação entre linhas. Isso quer dizer que as unidades mínimas de análise não são sílabas (como no caso da poesia), e que o jogo de construção de significação não se dá na relação que elas constróem entre si respeitando a restrição métrica; em narrativas orais, a construção de significação dá a partir das relações formais e semânticas que as linhas estabelecem entre si . Essas relações formais e semânticas se dão em termos de repetição e paralelismo (HYMES 1994, p.332).

A repetição e o paralelismo são estratégias que permitem estabelecer unidades maiores que as linhas, que eu chamei de estrofes. Já as relações de paralelismo e repetição de estrofes criam também unidades maiores que eu chamei de episódios. Como cada uma dessas unidades foi identificada em cada narrativa e sua contribuição para a construção da significação será explicado nos itens 3.1 e 3.2 a seguir.

\subsection{A viúva e os duendes}

Na primeira narrativa a ser apresentada, Manuel Erira conta quem são a viúva e os duendes. Por isso, eu a intitulei $A$ viúva e os duendes. Apresento a narrativa inteira a seguir.

\footnotetext{
${ }^{12} \mathrm{O}$ conceito de unidade entoacional de Chafe (1994) e sua aplicação na transcrição das narrativas será mais amplamente explicado o capítulo de metodología. Neste capítulo utilizarei o termo linha para me referir às unidades menores que compõem a análise, pois é esse o termo utilizado por Hymes (1994) no modelo de análise de narrativas orais.

${ }^{13}$ O próprio Chafe $(1994$, p.57) reconhece a sobreposição das definições de unidade entoacional e linha.
} 
bueno muchas gracias,

con respecto a los mitos y leyenda qué nos puede dar a conocer?

en cuanto a los mitos pues ant,

anteriormente,

había,

mucha estrategia de nuestros mayores que aparecían espíritu si?

entonces,

unos conversan que la,

la viuda,

eso le salía pues a los (com) a los enamorados si?

$\begin{array}{ll}\text { una persona una muchacha cuando, } & 9\end{array}$

iba por ejemplo el joven iba a ver la muchacha, $\quad 10$

tonces se le presentaba,

$\begin{array}{ll}\text { en forma de la novia, } & 12\end{array}$

pero lo total no era era (le) un espíritu, $\quad 13$

$\begin{array}{ll}\text { que se llama la viuda, } & 14\end{array}$

$\begin{array}{ll}\text { eso es en cuanto al (a) (al) al espíritu de los enamorados. } & 15\end{array}$

II.

(D)

en cuanto al duende, $\quad 16$

$\begin{array}{ll}\text { ese es un, } & 17\end{array}$

$\begin{array}{ll}\text { pues según la historia sagrada, } & 18\end{array}$

o la leyenda bíblica, $\quad 19$

dicen que fue un coro de ángeles que fueron arrojados, $\quad 20$ del cielo,

у que, 22

pues había como dice una rebelión de, 23

$\begin{array}{ll}\text { contra dios. } & 24\end{array}$

tonces, 25

y allá, $\quad 26$

los empujó como dice, $\quad 27$

que era un como decir un ejército, 28

y iban estaban (diz) que peliando, $\quad 29$

que Lucifer era el que comandaba, $\quad 30$

$\mathrm{y}, \quad 31$

contra Dios, $\quad 32$

que él quería ser más grande, $\quad 33$

(F) 
entonces como se iba a derrumbar, $\quad 34$

dice pues la historia (de) bíblica, $\quad 35$

que se iba a derrumbar el ángel San Rafael, $\quad 36$

o arcángel Sán Rafael si? $\quad 37$

tonces, $\quad 38$

a fin de que él no se caiga pues Dios dijo detente. 39

por eso quedaron unos en el agua otros en el (en el), $\quad 40$

en el fue(go), 41

los que alcanzaron a llegar al fuego pues se condenaron para siempre. $\quad 42$

los que quedaron en el aire son, 43

los espíritus que se encuentra en el aire en el agua en cualquier parte, $\quad 44$

y quedaron en las partes más como digo sólidas o, 45

o donde ellos pueden habitar, $\quad 46$

eh usted ha poseido de pronto,

le ha salido la viuda o algo o algún comentario aquí en el municipio?

Na narrativa $A$ viúva e os duendes há três ocorrências de en cuanto a (linhas 1, 15 e 16), duas delas ocorrendo uma em seguida da outra, ou seja paralelamente. A repetição de en cuanto a divide a narrativa em dois episódios (I. e II.). No primeiro episódio (I), , com o uso da expressão en cuanto $a$, o narrador abre a narrativa na linha 1 para contar as condições em que aparece a viúva, e o que acontece quando ela aparece; o episódio de viúva é fechado na linha 15 com a repetição da expressão en cuanto a. Já a terceira ocorrência dessa expressão abre o segundo episódio (II), que narra a história de criação dos duendes.

Dentro dessas grandes unidades temáticas há também uma estrutura, que no caso é construída pela repetição de entonces ou sua versão mais curta tonces (linhas 5, 11, 25, 34, 38). A repetição de entonces/tonces cria estrofes, que são unidades menores que os episódios. Como já mencionado, optei por codificá-las alfabeticamente (A, B, C, etc.). Além de uma divisão só guiada pela repetição de entonces, nota-se também que cada uma dessas unidades contem um ou mais elementos significativos que constróem a narrativa e estruturam a ação. O narrador abre a narrativa com a introdução do tema de que tratará sua narrativa (estrofe A): os mitos. Em seguida, e como pode ser visto na Tabela 3 , a estrofe B introduz não só o tópico — no caso, a Viúva —, mas também a fonte de informação unos, 
que codifica um referente indefinido ou genérico, do tipo alguns ou as pessoas; introduz ainda as personagens, no caso o moço a moça que namoram; e descreve as condições em que aparece o espírito - quando o moço visita a moça. Paralelamente, no episódio do Duende (II), a estrofe D introduz o tópico — o Duende — , introduz a fonte de informação — no caso a história sagrada ou a lenda bíblica —, e, por último, introduz as personagens — o coro de anjos e Deus. A descrição da ação ou os acontecimentos é feita na estrofe E.

\begin{tabular}{|l|l|l|}
\hline Elementos significativos de estruturação da ação & (I) A Viúva & (II) O Duende \\
\hline Criação do cenário & A & \\
\hline Introdução do Tópico & B & D \\
\hline Introdução da fonte de informação & B & D \\
\hline Introdução das personagens & B & D \\
\hline Descrição de condições/acontecimentos & B & E \\
\hline Descrição da ação & C & \\
\hline Apresentação do conflito & C & F \\
\hline Resolução do conflito & C & G \\
\hline Avaliação & C & G \\
\hline
\end{tabular}

Tabela 3 Elementos da narrativa e sua correspondência com unidades dentro da narrativa da Viúva e o Duende.

A estrofe $C$ descreve a ação da viúva, apresenta o conflito - quando o espírito toma forma da moça e engana o moço - a resolução do conflito - o fato de ela não ser a moça verdadeira -, e finalmente faz uma avaliação, nos termos de Labov e Waletzky (1967), ou seja, o narrador traz os eventos para o presente e os analisa de sua perspectiva na atualidade. Em 13, o autor nega que o espírito seja a namorada, e logo depois, em 14, ele fala que era a viúva. O interessante nessa sequência de linhas é que em 14 o autor escolhe usar um verbo no presente do indicativo, o que indica em primeiro lugar que se trata da perspectiva dele do presente, olhando para esses fatos no passado, e em segundo lugar, que ele tem um conhecimento no momento da enunciação, que os personagens não tinham no momento do evento quando a viúva tomou a forma da namorada e apareceu para o namorado. 
pero lo total no era era (le) un espíritu,

No caso do episódio (II), a estrofe F apresenta o conflito - o Anjo São Rafael ia ser expulso do céu. Na estrofe G, o conflito se resolve - Deus disse "pára” e o Anjo São Rafael não foi expulso do céu —, e também apresenta a avaliação - quando o autor resume onde estão os duendes no momento da enunciação e as suas condições atuais de habitação nas linhas 40 a 46.

por eso quedaron unos en el agua otros en el (en el),

en el fue(go),

los que alcanzaron a llegar al fuego pues se condenaron para siempre.

los que quedaron en el aire son,

los espíritus que se encuentra en el aire en el agua en cualquier parte,

y quedaron en las partes más como digo sólidas o,

o donde ellos pueden habitar,

Finalmente, é possível observar que os episódios (I) e (II) apresentam uma outra diferencia, que foi marcada com indentado das unidades entoacionais que apresentassem o uso da conjunção que, que indica o uso de discurso indireto. No episódio (I) a conjunção é utilizada só em uma ocasião (unidade entoacional 6), entanto que no episódio (II) seis vezes (unidades entoacionais 20, 22, 28, 30, 33, 36). No caso do episódio (II) a cada uso de que o narrador atualiza o verbo de fala, dicen que, como se reforçasse a fonte de informação. Já no episódio (I) a fonte de informação só é marcada uma vez, e a narrativa do que aconteceria com a viúva é narrada sem necessidade de atualizar a fonte. No caso, se trata de uma instância de discurso indireto livre, entanto que no episódio (II) se trata de uma instância de discurso indireto.

Temos então que a narrativa $A$ viúva e os duendes se estrutura em dois episódios: (I) que trata da viúva e (II) que conta a história dos duendes. Dentro desses dois episódios o narrador constrói a ação seguindo uma estrutura de: criação do cenário, introdução do 
tópico, introdução da fonte de informação, introdução dos personagens, descrições das condições ou acontecimentos, descrição da ação, apresentação do conflito, resolução do conflito, e avaliação. A diferença em termos da construção dos dois episódios é que a mesma estrutura da informação está expressada no caso do episódio (I) em três estrofes de quatro, seis e cinco linhas respectivamente (estrofe A: linhas 1-4; estrofe B: linhas 5-10; estrofe C: linhas 11-15) cada uma e, no caso do episódio (II), em quatro estrofes: as estrofes D, E e G têm nove linhas cada uma (estrofe D: linhas 16-24; estrofe E: linhas 25-33; estrofe G: linhas 38-46), e a estrofe $\mathrm{F}$ tem quatro linhas (linhas 34-37). O nível de detalhe do episódio (II) é maior do que no episódio (I).

\section{2. Índios enterrados}

A segunda narrativa que analisei no decorrer desta pesquisa, eu intitulei de Índios enterrados. Trata-se da história dos indígenas que se enterraram para se salvar dos conquistadores espanhóis. Apresento a narrativa inteira a seguir.

\section{Índios enterrados}

nuestros primeros primitivos que habitaron en este mundo terrenal.

\section{cuando ellos se enterraron,}

\section{eh ellos pasaron al mundo de abajo?}

correctísimo.

pues según la prehistoria dan,

que ellos se enterraban,

y se enterraban con todas las rique,

entre todo,

como era si era el cacique él se enterraba con toda la riqueza,

y que le tenían creencia, 
(que) que quedaba pues por fuera pa que los tape,

pero cuando ellos acordaron, 15

$\begin{array}{ll}\text { ya no ya pues se ahogaron, } & 16\end{array}$

ya no hubo aire dentro de donde estaban enterrado, $\quad 17$

II.

(E)

por eso a ellos se los halla, $\quad 18$

$\begin{array}{ll}\text { con su chicha con su morocho con todo ahí, } & 19\end{array}$

$\begin{array}{ll}\text { eh pues eso si hasta actualmente, } & 20\end{array}$

$\begin{array}{ll}\text { se ha encontrado bases de eso, } & 21\end{array}$

porque acá en la chorrera donde, $\quad 22$

tengo un lotecito, 23

allí se encontró como dice el cabello ollas todo eso, $\quad 24$

y no hace mucho que hallaron hasta la olla de chicha. 25

si? $\quad 26$

eso sí es verdad, $\quad 28$

pero ellos creían que pues van a salir de nuevo, $\quad 29$

no? $\quad 30$

en la conquista de los españoles ahí quedaron sepultados. 31

hasta ahora se los halla pero ya muertos no vivos. 32

(a)

usted qué cree que va a pasar en el futuro (con el) con el resguardo y con el cabildo?

A narrativa Índios enterrados está dividida em dois episódios. O primeiro deles conta a história dos antepassados indígenas que se enterraram para se salvar dos espanhóis durante a conquista. $O$ segundo episódio apresenta a avaliação da narrativa (LABOV \& WALETZKY 1967). O trânsito entre (I) e (II) se dá em termos de uma mudança de tempo. Em (I), fora a introdução do tema e da fonte de informação, temos que toda a narração é feita no passado. Em (II) temos uma mudança para o presente que indica o começo da fase de avaliação.

Esses episódios estão divididos em estrofes (A até H), que por sua vez são compostas por linhas (1 a 32). As linhas, como exposto acima, correspondem a unidades divididas segundo contornos entoacionais ou pausas (unidades entoacionais propostas por Chafe 
(1994)). A divisão entre estrofes se deu de formas diferentes nos episódios (I) e (II). Em (I), o critério para a divisão foi a repetição da conjunção que, introdutora do discurso indireto. O início está logo depois da introdução da fonte de informação (a pré-história) na linha 3, e de quem estaria reportando o discurso.

pues según la prehistoria dan, ${ }^{14}$

que ellos se enterraban,

y se enterraban con todas las rique,

entre todo,

como era si era el cacique él se enterraba con toda la riqueza,

y que le tenían creencia,

de que ellos cuando,

porque en la conquista,

cuando vinieron los españoles,

creyeron que enterrándose se van a salvar no?

y hubo uno que por ejemplo dice la historia,

(que) que quedaba pues por fuera pa que los tape,

pero cuando ellos acordaron,

ya no ya pues se ahogaron,

ya no hubo aire dentro de donde estaban enterrado,

\footnotetext{
${ }^{14} \mathrm{Eu}$ interpretei aqui o verbo dar com significado do tipo dizer/informar/contar, especialmente porque ele é seguido de ocorrências de discurso indireto. No entanto esse não é um uso comum no espanhol em casos em que se fala de alguma fonte de informação, como é o caso aqui. Talvez se trate de uma expansão do significado prototípico de dar, como quando se fala "Vou te dar uma ideia", em que o significado do processo real e físico de entregar um objeto para alguém é expandido para entregar objetos não físicos como uma ideia. No caso específico da narrativa Índios enterrados parece que o que é dado é a história do que teria acontecido com os indígenas. Esse uso específico pode ser explicado sob a luz do conceito de metáfora conceitual de Lakoff \& Johnson (1980) e de categorias radiais de Rosch (1987).
} 
Na estrofe B, o narrador conta da prática dos indígenas de se enterrar com todos os seus objetos valiosos. A estrofe $\mathrm{C}$ conta como esses indígenas acreditavam que podiam se enterrar para se salvar dos conquistadores espanhóis. Finalmente, em D, o narrador conta como eles se enterravam, que um que ficava fora para enterrar todos os outros, e como, por falta de ar, morreram e ficaram nos enterramentos. É possível ver como a conjunção que indica, em cada caso, um novo desenvolvimento na história, dando inclusive, uma ideia de sucessão.

O primeiro episódio apresenta uma estrutura similar àquela apresentada na Tabela 3 , no sentido de apresentar a mesma sequência de elementos significativos de estruturação da ação. Embora essa estrutura não corresponda à mesma quantidade de estrofes para cada elemento, há uma correspondência que parece interessante. A comparação é apresentada na Tabela 4 a seguir.

\begin{tabular}{|c|c|c|c|}
\hline Narrativa & $A$ viúva e os & uendes & Índios enterrados \\
\hline $\begin{array}{l}\text { Elementos significativos de } \\
\text { estruturação da ação }\end{array}$ & (I) A Viúva & (II) O Duende & (I) Índios enterrados \\
\hline Criação do cenário & A & & A \\
\hline Introdução do Tópico & $\mathrm{B}$ & $\mathrm{D}$ & $\mathrm{A}$ \\
\hline $\begin{array}{llll}\text { Introdução da fonte } & \text { de } \\
\text { informação } & & & \\
\end{array}$ & B & $\mathrm{D}$ & $\mathrm{A}$ \\
\hline Introdução das personagens & $\mathrm{B}$ & $\mathrm{D}$ & A \\
\hline $\begin{array}{ll}\text { Descrição } & \mathrm{de} \\
\text { condições/acontecimentos } & \end{array}$ & B & $\mathrm{E}$ & $\mathrm{B}$ \\
\hline Descrição da ação & $\mathrm{C}$ & & $\mathrm{B}$ \\
\hline Apresentação do conflito & $\mathrm{C}$ & $\mathrm{F}$ & $\mathrm{C}$ \\
\hline Resolução do conflito & $\mathrm{C}$ & $\mathrm{G}$ & $\mathrm{D}$ \\
\hline Avaliação & $\mathrm{C}$ & G & (II) \\
\hline
\end{tabular}

Tabela 4 Elementos da narrativa e sua correspondência com unidades dentro da narrativa Índios enterrados. Comparação com a narrativa A viúva e os duendes. 
No caso da narrativa Índios enterrados a função da avaliação não é refletida por uma estrofe só, mas integra o extenso segundo episódio da narrativa, que tem um estrutura própria. Nele, a estrofe E faz uma atualização da história dos índios enterrados. O narrador explica por que até agora (no momento da enunciação) se encontram os locais onde os indígenas foram enterrados com os seus objetos. Na estrofe F, o narrador conta uma outra historia, de como num terreninho que ele tem se acharam coisas de um cemitério indígena, com o intuito de reforçar a ideia de que esses enterros aconteceram de fato. Essa historinha dentro da avaliação serve para o narrador demonstrar a veracidade do que ele conta, além de trazer os fatos históricos para sua história pessoal. Imediatamente depois de contar a historinha do que foi encontrado no terreno dele, na estrofe G, o narrador declara que a história é verdadeira.

porque acá en la chorrera donde,

tengo un lotecito,

allí se encontró como dice el cabello ollas todo eso,

y no hace mucho que hallaron hasta la olla de chicha.

tons eso aguanta,

eso sí es verdad,

Na estrofe H, o falante faz um resumo da historia dos índios enterrados e uma avaliação final na linha 32, na qual fala que até agora se acham esses índios enterrados, mas que eles estão mortos e não vivos.

Neste capítulo descrevi as narrativas seguindo a proposta da etnopoética de Hymes (1997), o que me ajudou a estabelecer uma primeira organização das narrativas $A$ viúva e os duendes e Índios enterrados. Essa estrutura, que emergiu da observação da relação da forma com o conteúdo das narrativas, permitiu minha aproximação de forma geral ao 
significado desses discursos, e a maneira com que eles foram construídos tanto formal como conceitualmente. ${ }^{15}$

${ }^{15}$ A etnopoética de Hymes (1990) mostra que a existência de unidades entoacionais não responde só a critérios fonéticos ou acústicos, mas semânticos. Embora isso não seja relevante para Teoria de Espaços Mentais, este tipo de análise é interessante para o estudo de narrativas em geral, pois da para a narrativa oral um espaço que é ocupado maiormente pela narrativa escrita ou literária. 


\section{Metodologia}

Este capítulo descreve a natureza dos dados que foram analisados na pesquisa e o tratamento que dei a eles para poder fazer a análise. A seção 4.1. descreve como foi feita a obtenção dos dados por Arango Villalón e suas características quando chegaram a minhas mãos para a análise de narrativas aqui proposta. A seção 4.2. descreve como foi feita a transcrição das narrativas e a utilização do software ELAN para esse fim específico.

\subsection{Obtenção e natureza dos dados}

O corpus utilizado nesta pesquisa consta de aproximadamente 107 minutos de gravações de áudio feitas por Arango Villalón em 2011 na Reserva Indígena Pasto de Pastás em Aldana. As gravações da pesquisadora foram coletadas para sua pesquisa etnográfica, e são gravações de interações cotidianas de membros da comunidade entre si e com a pesquisadora, além de algumas entrevistas que ela fez durante a sua estada na Reserva.

Desses 107 minutos de gravação, eu trabalhei com uma das entrevistas, cuja duração é de aproximadamente 38 minutos. Nessa entrevista, Manuel Erira responde questões trazidas pelos antropólogos sobre costumes, crenças e plantas. A escolha da gravação foi determinada por alguns fatores de qualidade, de um lado, e alguns de interesse para a pesquisa, do outro. No que diz respeito à qualidade, o interesse principal foi o de privilegiar gravações que apresentassem boa qualidade de áudio; muitas apresentavam excessivo barulho de fundo ou interferência, e em algumas outras não era possível escutar claramente alguns dos participantes. O segundo grupo de fatores, o de interesse para a pesquisa, teve a ver com a qualidade narrativa das interações, isto é, com quanto o falante se vale de narrativas como um recurso explicativo, por exemplo. Dado que a pesquisa de Arango Villalón (2012) não é uma pesquisa sobre narrativas, a autora não recolheu histórias narradas pelos habitantes da reserva, e fez gravações que se encaixam mais no gênero de entrevista. Dentro dessas entrevistas há algumas que se destacam por apresentar o uso de narrativas como um recurso ilustrativo ou explicativo. A entrevista de Manuel Erira apresentava bastantes trechos desse tipo. 
Na gravação, Arango Villalón e dois colegas entrevistam Manuel Erira sobre a os mitos e lendas da região, sobre a relação dos habitantes da Reserva com o tempo e as rotinas de plantação e colheita, sobre sua relação com as plantas medicinais, e sobre o futuro da Reserva. Esses quatro eixos principais estruturam a entrevista, e em cada um deles há ocorrências de narrativas. Após selecionar as narrativas presentes na entrevista, escolhi aquelas que tinham uma alternância de Pretéritos Perfeito e Imperfeito, pelo fato de que o comportamento desses tempos verbais foi o que mais me chamou a atenção no material, tendo vindo a se tornar o foco principal da pesquisa. Após os dois processos de seleção foram escolhidas quatro narrativas para serem analisadas.

\subsection{Transcrição}

A entrevista de Manuel Erira foi transcrita na sua totalidade, por meio do software ELAN, desenvolvido pelo Instituto Max Planck de Psicolinguística. Esse software apresenta algumas vantagens para o tratamento de dados de áudio e vídeo. A primeira delas é que é um software desenvolvido para pesquisa em linguística; além disso é distribuído gratuitamente na internet. No que diz respeito às vantagens técnicas, ele permite que a transcrição seja feita em sincronia com o áudio e o vídeo, ${ }^{16}$ de forma que na transcrição fica imediatamente registrada a localização e a duração dos enunciados. Além disso, o programa oferece a possibilidade de transcrever, em diferentes trilhas, os diferentes tipos de categorias de análise, comentários e informações, e poder visualizá-las a qualquer momento em sincronia com o áudio e a imagem. Eu, por exemplo, optei por transcrever a fala em uma trilha, e criei quatro trilhas adicionais para marcar: verbos isolados, advérbios temporais, tempo verbal como descrito na gramática tradicional do espanhol, e cálculos temporais de Reichenbach (1974) (ver a Figura 1). Na teoria de espaços mentais o primitivo discursivo PONTO DE VISTA é identificado por meio de algumas estratégias, dentre elas cálculos temporais-aspectuais, que serão o foco desta dissertação. ${ }^{17}$

\footnotetext{
${ }^{16}$ Nesta pesquisa os dados são unicamente de áudio, pelo que as propriedades do ELAN no que se refere à utilização de vídeo não foram exploradas.

${ }^{17} \mathrm{O}$ funcionamento desse primitivo discursivo será amplamente explorado no capítulo de teoria e nas análises.
} 
A marcação nas trilhas de categorias temporais se deve a que em espanhol o ponto de vista é obtivo a través do cálculo temporal-aspectual.

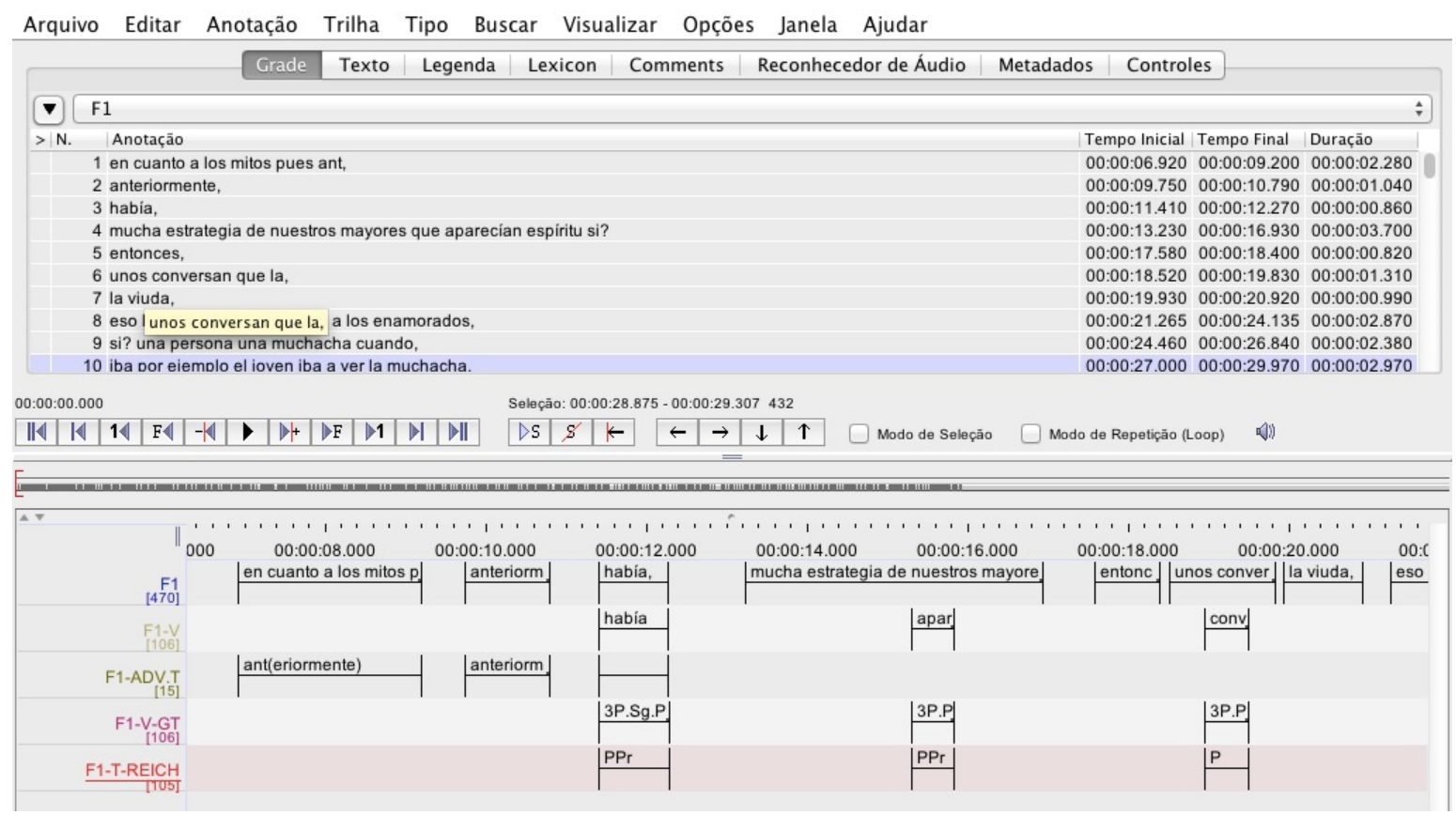

Figura 1 Trilhas utilizadas na transcrição da fala de Manuel Erira (F1) no software ELAN. F1: Falante 1; F1-V: Falante 1, Verbos Isolados; F1-ADV-T: Falante 1, Advérbios temporais isolados; F1-V-GT: Falante 1, Formas verbais segundo a gramática tradicional do espanhol; F1-T-REICH: Falante 1, Cálculos temporais segundo Reichenbach (1974).

As falas de Manuel Erira e dos quatro entrevistadores (trilhas nomeadas: F1, E1, E2, E3, e E4) foram transcritas seguindo a proposta de Chafe (1994) de segmentação do fluxo da fala em unidades entoacionais. Quando se lida com fala, sua segmentação envolve uma escolha metodológica relevante, pois sabemos que a fala não vem segmentada como a escrita; ao falarmos, produzimos um fluxo constante de som, em que as pausas nem sempre corresponderiam à estrutura de um texto escrito ou a alguma estrutura teoricamente concebida; em que mudamos de ideia; em que deixamos sentenças no meio do caminho; em que nos interrompemos. Ao transcrever fala, o pesquisador deve fazer uma escolha metodológica sobre como representar graficamente esse fluxo, de maneira que não se imponha à fala a estrutura da escrita ou de alguma teoria de gramática. As unidades entoacionais foram propostas por Chafe (1994) a partir de, e especificamente para, a análise de fala. Uma unidade entoacional é um segmento de fala que é identificável por uma série 
de fatores acústicos tais como: i) pausas na vocalização; ii) mudanças na velocidade da fala (aceleração e desaceleração); iii) queda da frequência fundamental (pitch) no fim de uma unidade; iv) mudanças de qualidade da voz (CHAFE 1994, p.60). Além dos fatores acústicos, as unidades entoacionais coincidem com o foco de consciência de um falante em um determinado momento, ou seja, são unidades que contêm a quantidade de informação à qual um falante pode prestar atenção em qualquer momento dado; por isso, muitas vezes, a unidades entoacionais parecem expressar ideias completas.

Para a transcrição, segui também algumas marcas propostas no modelo de transcrição de Chafe (1994): (,) para marcar uma queda no tom não coincidente com a finalização de uma sentença; (.) para a queda no tom coincidente com a finalização de uma sentença; (?) para mudança de tom coincidente com perguntas de resposta sim/não; e (@) para marcar riso.. ${ }^{18}$ Finalmente, a transcrição pode ser extraída como texto e fica como apresentado na Figura 2.

As trilhas F1-V e F1-ADV-T apresentam as formas verbais isoladas, e os advérbios temporais isolados, respectivamente. Na teoria de espaços mentais o primitivo discursivo PONTO DE VISTA é identificado por meio de algumas estratégias, dentre elas cálculos temporais-aspectuais, que serão o foco desta dissertação. ${ }^{19}$ Nessas trilhas transcrevi cada verbo ou advérbio temporal encontrado em todas as unidades entoacionais. A trilha F1-V facilitou a criação das trilhas F1-V-GT e F1-V-REICH, pois permitiu a criação de correspondências das categorias de análise da gramática tradicional e do modelo de Reichenbach (1974) com os verbos presentes na fala do Falante 1. Em casos em que uma unidade entoacional continha mais de uma forma verbal, essa seleção da trilha F1-V facilitou o trabalho de classificação das trilhas seguintes, pois criou unidades menores e

\footnotetext{
${ }^{18}$ A proposta de transcrição de Chafe (1994) abrange mais símbolos, mas esses não se faziam necessários para a minha pesquisa por dois motivos. Primeiramente, muitos deles são utilizados para marcar pausas e a sua duração, mas o ELAN permite ver as pausas nas trilhas, além de permitir ver a sua duração tanto na interface do programa, quanto na transcrição corrida que é possível extrair do mesmo. Em segundo lugar, o autor propõe alguns símbolos para marcar a transcrição de conversas, que não são o objeto desta pesquisa.

${ }^{19} \mathrm{O}$ funcionamento desse primitivo discursivo será amplamente explorado nos capítulos 5 e 6 dessa dissertação.
} 
resolveu o problema de ter que encaixar mais de uma categoria na mesma unidade entoacional.

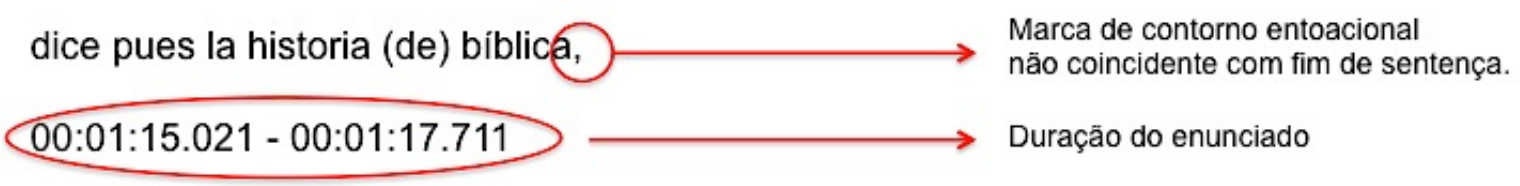

que se iba a derrumbar el ángel San Rafaêl. $\longrightarrow$ Marca de contorno entoacional 00:01:18.006 - 00:01:21.136

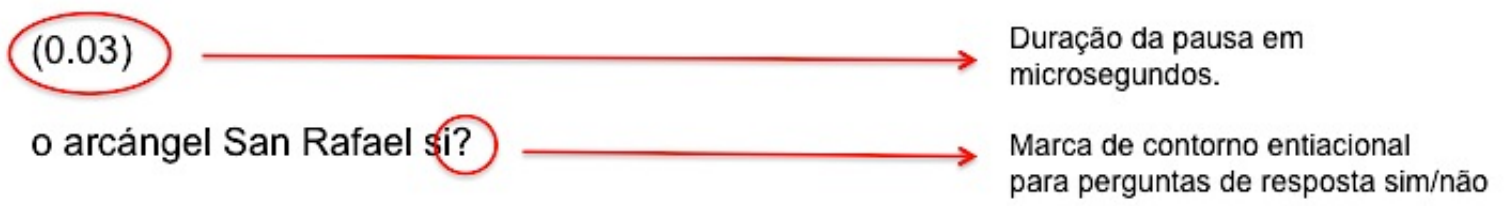

00:01:21.171 - 00:01:22.831

Figura 2 Transcrição extraída do ELAN com marcação temporal.

As trilhas F1-V-GT e F1-V-REICH foram preenchidas por meio do uso da ferramenta de vocabulário controlado. O vocabulário controlado permite criar um grupo fechado de elementos que podem ser utilizados para caracterizar a informação contida numa trilha. $\mathrm{O}$ vocabulário controlado para a trilha F1-V-GT (Falante 1-Verbos-gramática tradicional) foi construído a partir dos nomes dados a cada tempo verbal na Nueva Gramática de la Lengua Española (2010) e são apresentados na Tabela 5. 


\begin{tabular}{|c|c|c|c|c|}
\hline $\begin{array}{l}\text { Vocabulário } \\
\text { Controlado }\end{array}$ & Pessoa & $\begin{array}{l}\text { Número } \\
(\mathrm{SG}) /(\mathrm{PL})\end{array}$ & Tempo Verbal & Exemplo \\
\hline 1SGPrS & 1 & $\mathrm{SG}$ & Presente Simple & \multirow[t]{6}{*}{ Ella come } \\
\hline 2SGPrS & 2 & $\mathrm{SG}$ & Presente Simple & \\
\hline 3SGPrS & 3 & $\mathrm{SG}$ & Presente Simple & \\
\hline 1PLPrS & 1 & PL & Presente Simple & \\
\hline 2PLPrS & 2 & PL & Presente Simple & \\
\hline 3PLPrS & 3 & PL & Presente Simple & \\
\hline 1SGPrPr & 1 & SG & Presente Progressivo & \multirow{6}{*}{$\begin{array}{l}\text { Ella está } \\
\text { comiendo }\end{array}$} \\
\hline 2SGPrPr & 2 & SG & Presente Progressivo & \\
\hline 3SGPrPr & 3 & SG & Presente Progressivo & \\
\hline 1PLPrPr & 1 & PL & Presente Progressivo & \\
\hline 2PLPrPr & 2 & $\mathrm{PL}$ & Presente Progressivo & \\
\hline 3PLPrPr & 3 & PL & Presente Progressivo & \\
\hline 1SGPPS & 1 & SG & Pretérito Perfecto Simple & \multirow[t]{6}{*}{ Ella comió } \\
\hline 2SGPPS & 2 & $\mathrm{SG}$ & Pretérito Perfecto Simple & \\
\hline 3SGPPS & 3 & SG & Pretérito Perfecto Simple & \\
\hline 1PLPPS & 1 & PL & Pretérito Perfecto Simple & \\
\hline 2PLPPS & 2 & PL & Pretérito Perfecto Simple & \\
\hline 3PLPPS & 3 & $\mathrm{PL}$ & Pretérito Perfecto Simple & \\
\hline 1SGPPC & 1 & SG & $\begin{array}{l}\text { Pretérito Perfecto } \\
\text { Compuesto }\end{array}$ & \multirow[t]{5}{*}{$\begin{array}{l}\text { Ella ha } \\
\text { comido }\end{array}$} \\
\hline 2SGPPC & 2 & SG & $\begin{array}{l}\text { Pretérito Perfecto } \\
\text { Compuesto }\end{array}$ & \\
\hline 3SGPPC & 3 & SG & $\begin{array}{l}\text { Pretérito Perfecto } \\
\text { Compuesto }\end{array}$ & \\
\hline 3PLPPC & 1 & $\mathrm{PL}$ & $\begin{array}{ll}\text { Pretérito } & \text { Perfecto } \\
\text { Compuesto } & \end{array}$ & \\
\hline 2PLPPC & 2 & $\mathrm{PL}$ & $\begin{array}{l}\text { Pretérito Perfecto } \\
\text { Compuesto }\end{array}$ & \\
\hline
\end{tabular}




\begin{tabular}{|c|c|c|c|c|}
\hline 3PLPPC & 3 & PL & $\begin{array}{ll}\text { Pretérito } & \text { Perfecto } \\
\text { Compuesto } & \end{array}$ & \\
\hline 1SGPI & 1 & SG & Pretérito Imperfecto & \multirow[t]{6}{*}{ Ella comía } \\
\hline 2SGPI & 2 & SG & Pretérito Imperfecto & \\
\hline 3SGPI & 3 & SG & Pretérito Imperfecto & \\
\hline 1PLPI & 1 & PL & Pretérito Imperfecto & \\
\hline 2PLPI & 2 & $\mathrm{PL}$ & Pretérito Imperfecto & \\
\hline 3PLPI & 3 & $\mathrm{PL}$ & Pretérito Imperfecto & \\
\hline 1SGPPr & 1 & SG & Pasado Progresivo & \multirow{6}{*}{$\begin{array}{l}\text { Ella estaba } \\
\text { comiendo }\end{array}$} \\
\hline 2SGPPr & 2 & $\mathrm{SG}$ & Pasado Progresivo & \\
\hline 3SGPPr & 3 & SG & Pasado Progresivo & \\
\hline 1PLPPr & 1 & $\mathrm{PL}$ & Pasado Progresivo & \\
\hline 2PLPPr & 2 & $\mathrm{PL}$ & Pasado Progresivo & \\
\hline 3PLPPr & 3 & PL & Pasado Progresivo & \\
\hline 1SGPPc & 1 & SG & $\begin{array}{l}\text { Pretérito } \\
\text { Pluscuamperfecto }\end{array}$ & \multirow[t]{6}{*}{$\begin{array}{l}\text { Ella había } \\
\text { comido }\end{array}$} \\
\hline 2SGPPc & 2 & SG & $\begin{array}{l}\text { Pretérito } \\
\text { Pluscuamperfecto }\end{array}$ & \\
\hline 3SGPPc & 3 & SG & $\begin{array}{l}\text { Pretérito } \\
\text { Pluscuamperfecto }\end{array}$ & \\
\hline 1PLPPc & 1 & PL & $\begin{array}{l}\text { Pretérito } \\
\text { Pluscuamperfecto }\end{array}$ & \\
\hline 2PLPPc & 2 & PL & $\begin{array}{l}\text { Pretérito } \\
\text { Pluscuamperfecto }\end{array}$ & \\
\hline 3PLPPc & 3 & PL & $\begin{array}{l}\text { Pretérito } \\
\text { Pluscuamperfecto }\end{array}$ & \\
\hline 1SGFS & 1 & SG & Futuro Simple & \multirow{4}{*}{$\begin{array}{l}\text { Ella } \\
\text { comería / } \\
\text { Ella iba a } \\
\text { comer }\end{array}$} \\
\hline 2SGFS & 2 & SG & Futuro Simple & \\
\hline 3SGFS & 3 & SG & Futuro Simple & \\
\hline 1PLFS & 1 & $\mathrm{PL}$ & Futuro Simple & \\
\hline
\end{tabular}




\begin{tabular}{|c|c|c|c|}
\hline 2PLFS & 2 & PL & Futuro Simple \\
\hline 3PLFS & 3 & PL & Futuro Simple \\
\hline
\end{tabular}

Tabela 5 Vocabulário controlado. Trilha F1-V-GT. Categorías da Nueva Gramática de la Lengua Española (2010).

A trilha F1-V-REICH (Falante1-Verbos-Reichenbach) classifica os verbos da transcrição, que foram marcados na trilha F1-V-GT a partir das categorias da gramática tradicional, segundo as relações temporais que esses estabelecem com o aqui/agora da enunciação seguindo o modelo de Reichenbach (1974). O autor propõe que as categorias temporais da língua são interpretáveis por meio das relações de anterioridade, concomitância e posterioridade que o Tempo de Evento estabelece com o Tempo da Enunciação e com o Tempo de Referência, como ilustrado na Figura 3. O Tempo da Enunciação é o que acima chamei de aqui/agora da enunciação, ou seja o momento em que um falante de carne e osso profere qualquer enunciado. O Tempo de Referência estabelece a relação entre os Tempos de Enunciação e de Evento, e é o momento com referência ao qual um enunciado qualquer deve ser interpretado. Já o Tempo de Evento é aquele que é descrito pela frase verbal no enunciado, ou seja, o tempo que vai ser interpretado segundo sua relação com os tempos de Referência e Enunciação. Em um enunciado como Em abril do ano passado, Maria já tinha defendido o mestrado, o evento de Maria defender o mestrado é anterior a um Tempo de Referência estabelecido por Em abril do ano passado, que por sua vez é anterior ao Tempo da Enunciação. 


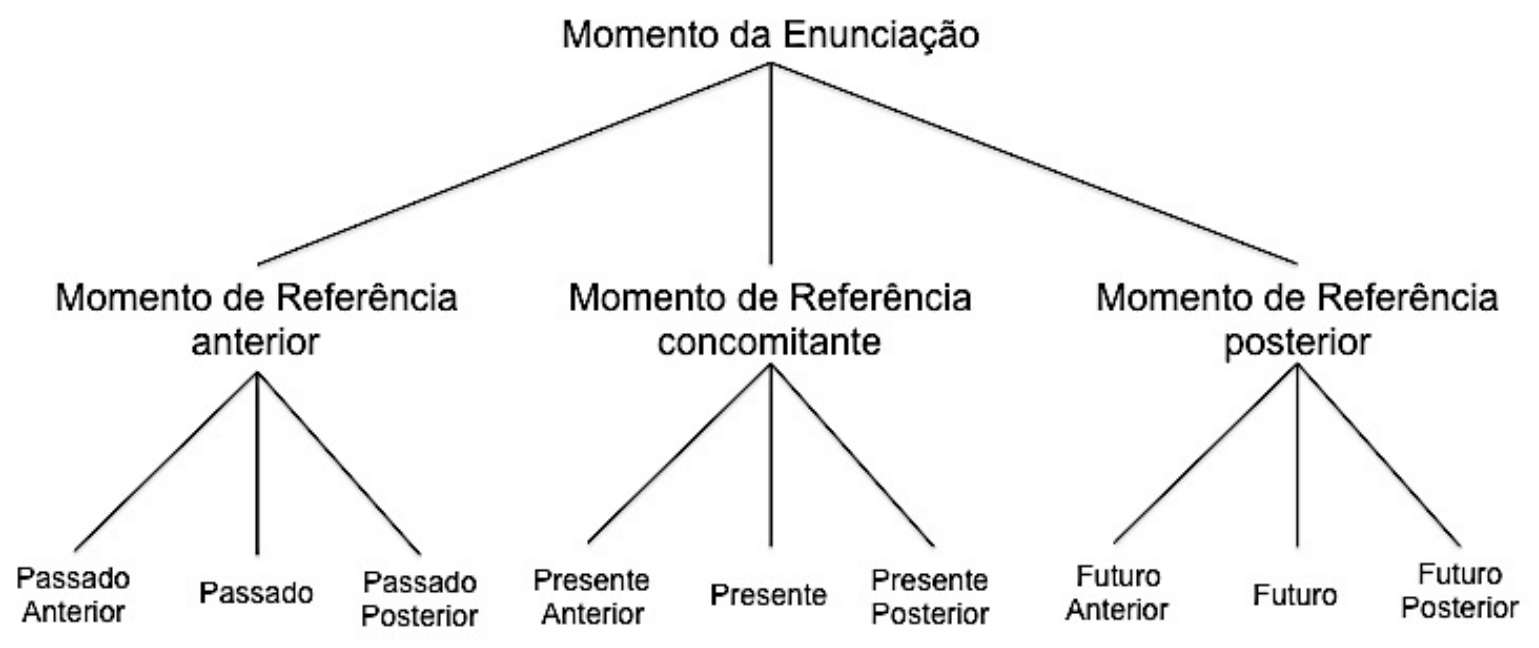

Figura 3 Organização de referências temporais no discurso em termos de anterioridade e posterioridade, segundo proposta de Reichenbach (1974).

Escolhi chamar Passado o Tempo de Evento concomitante ao Tempo de Referência anterior ao Tempo de Enunciação; Presente é o nome do Tempo de Evento concomitante ao Tempo de Referência concomitante ao Tempo de Enunciação; e Futuro é o Tempo de Evento concomitante ao Tempo de Referência posterior ao Tempo de Enunciação . Os não concomitantes chamei de Passado Anterior e Passado Posterior, Presente Anterior e Presente Posterior, e Futuro Anterior e Futuro Posterior. Reichenbach (1974) propõe a classificação dos tempos gramaticais do inglês, mas nem todos as possibilidades são preenchidas pela língua (nem necessariamente por qualquer língua), e há tempos verbais que se encaixam em mais de uma relação.

Fiorin (2005) utilizou o mesmo modelo do Reichenbach (1974) e aplicou-o ao português, mas de novo algumas formas verbais preenchem mais de uma possibilidade de relação temporal. É o caso do que o autor chama de Pretérito Perfeito 1 e Pretérito Perfeito 2, cujas marcas morfológicas de tempo são as mesmas, e que correspondem ao Pretérito Perfeito Simples na gramática tradicional. O Pretérito Perfeito 1 corresponde ao Tempo de Evento anterior ao Tempo de Referência concomitante ao Tempo de Enunciação, ou seja um Presente Anterior; o autor dá como exemplo uma sentença como "Sou muito sensível às relações humanas, e habituei-me a ver pelo menos três vezes por semana estes jovens que aqui tenho diante de mim" tomada de A volta do gato preto de Érico Veríssimo 
(FIORIN 2005, p.152). Já o Pretérito Perfeito 2 é um Tempo de Evento concomitante ao Tempo de Referência anterior ao Tempo de Enunciação, ou seja o Passado, na classificação adotada para esta pesquisa. Fiorin (2005, p.155) usa como exemplo do Pretérito Perfeito 2 a sentença "No dia 29 de dezembro, o Senado condenou o presidente Collor à pena de inabilitação política por oito anos". Fica evidente como as formas do Pretérito Perfeito 1 e 2 são preenchidas por verbos na forma do Pretérito Perfeito Simples da gramática tradicional, e sua interpretação como Pretérito Perfeito 1 ou 2 depende de outras referências temporais que não a morfologia verbal. Por isto, preferi nomear as categorias da forma exposta no parágrafo anterior e ilustrada na Tabla 6. Isso também facilitou a criação do vocabulário controlado da trilha F1-V-REICH, que é apresentado na Tabla 6.

\begin{tabular}{|l|l|}
\hline $\begin{array}{l}\text { Vocabulario } \\
\text { Controlado }\end{array}$ & Descrição \\
\hline Pr & Presente \\
\hline PrA & Presente Anterior \\
\hline PrP & Presente Posterior \\
\hline P & Passado \\
\hline PA & Passado Anterior \\
\hline PP & Passado Posterior \\
\hline F & Futuro \\
\hline FA & Futuro Anterior \\
\hline FP 6 Vocabulário controlado. Trilha F1-V-REICH. Categorías temporais \\
\multicolumn{2}{|c|}{ adaptadas de Reichenbach (1974). }
\end{tabular}

A marcação feita na trilha F1-V-REICH foi especialmente útil para a posterior construção dos mapeamentos de espaços mentais, especialmente no que toca à estruturação de espaços no eixo temporal, ou seja, para identificar a relação de anterioridade e posterioridade das referências temporais em relação ao momento da enunciação. Já a classificação nas categorias da trilha F1-V-GT permitiu fazer a busca de presença de Pretéritos Perfeito e Imperfeito, que são o foco desta pesquisa. 
Por último, fiz uma análise longitudinal das narrativas seguindo o Modelo de Espaços Mentais e criando os esquemas apresentados nos capítulos de análise. 


\section{Teoria de espaços mentais: expansão e aplicação ao estudo de narrativas}

Para a linguística cognitiva, a linguagem é uma manifestação superficial de construções cognitivas altamente abstratas (FAUCONNIER 1997, p.34), e nosso raciocínio e nossa interação com outros seres humanos e com o mundo dependem dessas construções cognitivas. Esses construtos mentais são denominados espaços mentais e são domínios cognitivos que constituem o substrato de processos cognitivos como o pensamento e o discurso. Do ponto de vista da produção de um discurso, a língua é concebida como a manifestação da organização desses espaços; por outro lado, numa situação de interação, ela é, ao mesmo tempo, um conjunto de instruções para a (re)construção dos espaços por parte do interlocutor. Os espaços vão se ativando no decorrer do discurso e nessa sucessão de ativações se constrói o significado de unidades linguísticas: as expressões não têm significado em si mesmas, mas têm potencial de significado, o que significa que só quando inseridas em um contexto discursivo é que o seu significado é plenamente construído (FAUCONNIER 1997, p.37). ${ }^{20}$ Em seu processo dinâmico de sucessão, os espaços mentais se organizam em uma relação de subordinação tal que um espaço E' se subordina a um espaço E, e E, por sua vez, é o espaço pai de E' (FAUCONNIER 1997, p.38). ${ }^{21}$ Essas relações de subordinação criam uma rede de estruturação hierárquica, que, no entanto, não impede que o falante e o ouvinte possam retomar espaços anteriores ou gerar espaços novos fora da ordem pré-estabelecida. Além disso, não há limitações quanto ao número de espaços E' que podem se subordinar a um espaço E.

Para a caracterização desses domínios cognitivos que são os espaços mentais, Fauconnier propõe três primitivos discursivos, a partir dos quais todo discurso se organiza: BASE, FOCO e PONTO DE VISTA. O espaço BASE é aquele que dá início a um discurso qualquer e ao qual é sempre possível retornar. Fauconnier também se refere ao espaço

\footnotetext{
${ }^{20}$ A ideia de ativação aqui é análoga ao conceito de estados de ativação da consciência de Chafe, que propõe que a consciência está permanentemente mudando entre o estado focal (ativo), estado periférico (semiativo) e estado inconsciente (inativo) (CHAFE 1994, p.53). Acredito que podem se aplicar esses conceitos de atividade à dinâmica de construção de espaços mentais e às relações entre eles.

${ }^{21}$ Daqui em diante usarei E como abreviação de Espaço, contrariamente à abreviação M usada por Fauconnier para falar de espaços mentais genéricos.
} 
BASE como espaço da realidade, ou espaço da realidade ficcional (FAUCONNIER 1997, p.49-50). Cutrer (1994) caracteriza esse espaço como o centro dêitico no qual se ancora o discurso (p.22). Algumas observações se fazem necessárias neste momento. Primeiramente, o centro dêitico de Cutrer é concebido como sendo interno à narrativa. Como observado por alguns autores e discutido logo a seguir, nem Fauconnier, nem Cutrer fazem qualquer referência à enunciação e à construção dêitica a partir da qual a própria narrativa é criada. Em segundo lugar, os diferentes usos da palavra realidade devem ser tomados com cuidado, pois podem se referir (i) à realidade do mundo fora da mente; (ii) ao que é aceito como real dentro do mundo da narrativa (realidade ficcional); ou (iii) à realidade em oposição a conceitos como espaço da CRENÇA, espaço HIPOTÉTICO ou espaço do DESEJO. Daqui em diante vou assumir a postura de que toda construção já é uma abstração do mundo, especialmente na análise de narrativas, o que elimina a possibilidade de falar de realidade como o mundo fora da mente. Em se tratando da palavra realidade farei uma distinção entre realidade ficcional, ou seja o que se aceita como real dentro do mundo da narrativa, e espaço REAL em oposição a espaço da CRENÇA, espaço HIPOTÉTICO ou espaço do DESEJO.

McCleary e Viotti (2014), entre outros, problematizam a noção de realidade atribuída por Fauconnier ao espaço BASE (por vezes chamado espaço R, de realidade), pelo fato de ele não ter nenhuma relação evidente com o ato da enunciação (p.127), especialmente quando entendido como o espaço de realidade fíccional. Com o fim de incluir o ato da enunciação, indispensável para a análise de narrativas sinalizadas e interação face-a-face, os autores partem da ideia de espaço semiótico de comunicação proposto por Brandt e Brandt (2005) e Oakley (2009), para a construção de um espaço mental em que se encontram o enunciador e o enunciatário, no tempo e lugar em que a enunciação é produzida. Esse espaço é chamado espaço real por McCleary e Viotti (2014), seguindo a nomenclatura de Liddell (2003) para a análise de discursos sinalizados. Neste trabalho prefiro me referir a esse espaço como espaço da enunciação. Para McCleary e Viotti (2014), esse espaço é intersubjetivo e inclui, necessariamente, a assunção por parte de todos os participantes do ato comunicativo de que sua noção de espaço real é compatível com a dos demais (p.128). 
McCleary e Viotti propõem, ainda, que a análise de narrativas depende de um outro espaço, para além da inclusão do espaço da enunciação: trata-se do espaço do narrador. Esse espaço resulta da integração de um espaço da enunciação (EE) (Figura 4, input 1) e um espaço elaborado pela informação genérica de narração (Figura 4, espaço frame de narração (FN), input 2).

O espaço BASE deve, então, ser tomado como o aquele que dá início a um discurso qualquer, mas suas características de 'centro dêitico' (CUTRER 1994) só podem ser entendidas como sendo elaboradas a partir de um espaço do narrador (EN), que, por sua vez, é produto da integração de dois outros espaços, um deles o espaço da enunciação, que é o espaço em que se ancora a dêixis de qualquer ato comunicativo, o outro sendo o espaço frame de narração mencionado acima. ${ }^{22}$ Dentro dessa visão, o espaço BASE e todos os outros primitivos discursivos fazem parte do domínio da história, enquanto o espaço do narrador - EN - faz parte do domínio narrativo. ${ }^{23}$

\footnotetext{
${ }^{22}$ Como já dito, Cutrer (1994, p.73) não menciona o espaço da enunciação nem esclarece a relação da BASE com o ato da enunciação; no entanto, afirma que o espaço BASE é sempre presente por default. A meu ver, isso só é possível se o espaço BASE herdar da enunciação a temporalidade, que é por definição o agora do ato enunciativo. Além disso, não pode se chamar o espaço BASE de centro dêitico sem fazer referência à enunciação.

${ }^{23}$ A noção de frame, proposta por Fillmore (2003) será explicada mais adiante no texto.
} 


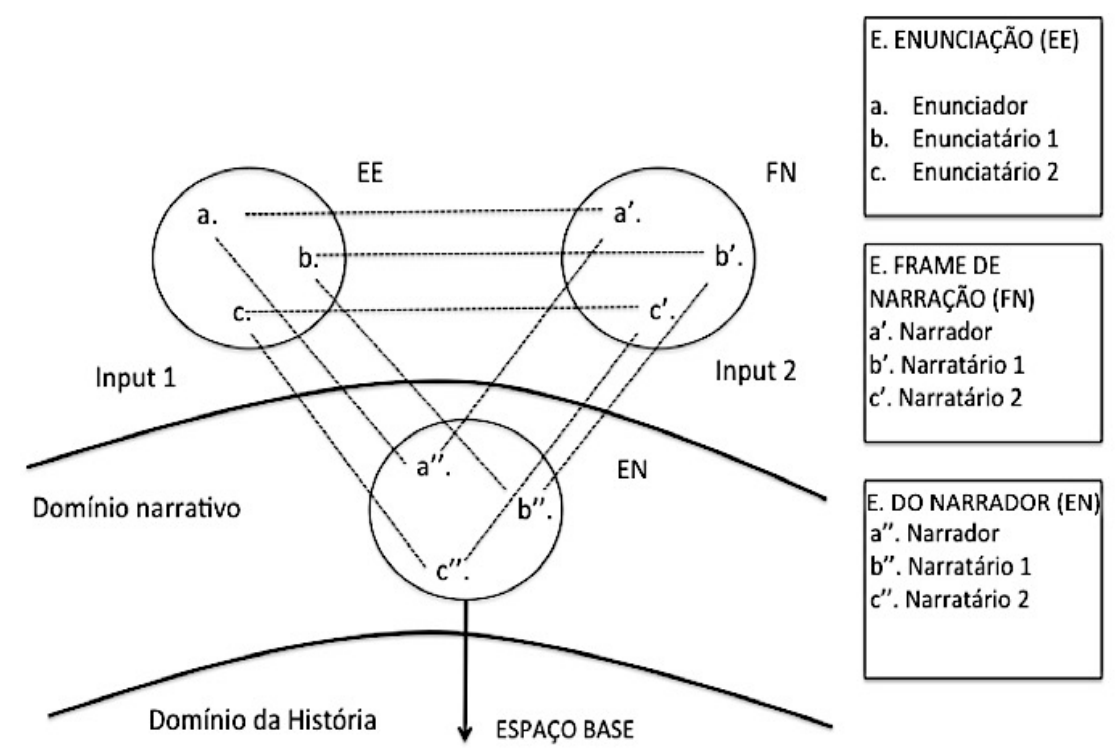

\section{Figura 4 Criação do espaço do narrador e do espaço BASE desenvolvida a partir da proposta de McCleary e Viotti (2014).}

O espaço FOCO é o espaço que, em um determinado momento, é mais ativo, na medida em que é o espaço em que o significado está sendo construído. É também o centro ou foco de atenção, no sentido de que é o espaço de que trata um determinado enunciado (CUTRER 1994, p.22).

O terceiro primitivo - o PONTO DE VISTA - é o espaço a partir do qual se constroem e acessam outros espaços (FAUCONNIER 1997, p.49). É o espaço a partir do qual as situações são vistas/conceitualizadas; ou seja, trata-se do centro de conceitualização e consciência de um self a quem se atribui um discurso. A noção de PONTO DE VISTA na teoria de espaços mentais é equiparável à noção de vantage point (ponto de visualização) da gramática cognitiva, por ser o local, real ou ficcional, no qual se situam o falante e/ou o ouvinte, e do qual eles observam e descrevem uma determinada cena (LANGACKER 2008, p.75). O ponto de vista canônico é aquele do falante, mas isso não impede que outros pontos de vista sejam explorados ao longo de um discurso. ${ }^{24}$

\footnotetext{
${ }^{24}$ Ao longo deste texto utilizarei maiúsculas para me referir aos primitivos discursivos (BASE, FOCO, PONTO DE VISTA, EVENTO) e minúsculas para noções de senso comum como ponto de vista e foco de atenção.
} 
Aqui é preciso ampliar um pouco a discussão sobre o que seria o PONTO DE VISTA na teoria de espaços mentais. Além disso, é preciso problematizar a relação do conceito de PONTO DE VISTA proposto por Fauconnier (1997) e a noção de focalização proposta por Genette (1980). Começarei por esta última.

Para Genette (1980) o ponto de vista, ou focalização na narrativa tem a ver com a pergunta quem vê?, que pode ser respondida de várias maneiras. Quem vê pode ser o narrador ou alguma das personagens; inclusive pode naturalmente ser um narrador que é ao mesmo tempo uma personagem da história. É importante notar que há uma distinção importante entre quem vê e quem fala em uma narrativa. Suponhamos um caso em que um evento é narrado por um narrador omnisciente da perspectiva de várias personagens. Nesse caso, quem vê é, em cada caso, uma personagem diferente, mas quem fala é sempre o narrador. Outro caso é quando o narrador dá a voz para uma personagem no discurso direto. Neste caso quem fala e quem vê são a mesma personagem (GENETTE 1980, p.186).

Esses jogos de ponto de vista e voz nas narrativas resultam na proposta do autor (GENETTE 1980, pp. 189-190) de que, no discurso narrativo, há três tipos de modos de narrar: (i) a narrativa não-focalizada, no caso em que há um narrador omnisciente que sabe mais do que qualquer personagem, e que por isso não narra do ponto de vista de nenhuma personagem, mas de um ponto de vista global de quem sabe e vê tudo; (ii) a narrativa com focalização interna, no caso em que o ponto de vista é de alguma personagem; ou (iii) a narrativa com focalização externa, no caso em que a personagem atua na frente do leitor sem ele ter nenhum acesso aos seus sentimentos ou pensamentos, e que é chamada também de narrativa objetiva ou behaviorista (GENETTE 1980, p.188).

Tendo a proposta de Genette (1980) em mente, vamos ao que, na teoria de espaços mentais, se entende como o primitivo discursivo PONTO DE VISTA. Segundo Fauconnier (1997, p.49), o PONTO DE VISTA é o espaço a partir do qual se estruturam e acessam outros espaços. Em algumas ocasiões, esse PONTO DE VISTA é concebido como o ponto de vista de alguma personagem, como no exemplo clássico da historinha de Aquiles e a 
tartaruga, que Fauconnier (1997) utiliza para explicar o funcionamento do modelo. O autor propõe a seguinte análise para o discurso a seguir:

Achilles sees a tortoise. He chases it. He thinks that the tortoise is slow and that he will catch it. It probably won't take long.

A primeira sentença abre um espaço BASE (B), que, naquele momento do discurso, é também FOCO, porque é o que está sendo elaborado, e PONTO DE VISTA, porque é o espaço a partir do qual outros espaços vão ser construídos. A segunda sentença continua a elaborar internamente esse espaço B. A terceira sentença abre um espaço da CRENÇA $(\mathrm{M})$, pois tem o construtor de espaço da crença he thinks. Nesse ponto no discurso M é FOCO, pois é o espaço sendo elaborado, e B é tanto BASE como PONTO DE VISTA, pois é a partir dele que se constrói o espaço da CRENÇA M. Na quarta sentença o verbo no futuro will abre um espaço do futuro $\mathrm{W}$, que é FOCO. O autor afirma que até esse momento o espaço B é PONTO DE VISTA, e que o primeiro movimento de PONTO DE VISTA nesse discurso se dá com a última sentença It probably won't take long. Neste ponto no discurso, o FOCO volta ao espaço da CRENÇA M, e o PONTO DE VISTA passa do espaço B para o espaço M. Segundo Fauconnier (1997, p.50), nesse ponto a informação está sendo apresentada do ponto de vista de Aquiles. Até então não houve nenhuma afirmação sobre de quem era o ponto de vista antes disso, o que é explicável pelo fato de que a teoria de espaços mentais não foi proposta para lidar especificamente com a estruturação de narrativas, e por isso não havia, num primeiro momento, uma preocupação com a figura do narrador.

Embora em casos como esse a teoria afirme que o ponto de vista é da personagem, não se pode fazer uma equiparação entre a proposta de focalização de Genette (1980) e a de PONTO DE VISTA nos espaços mentais. Suponha-se um exemplo como o seguinte:

Maria e eu fomos ao cinema e ela me contou que já tinha assistido ao filme e tinha gostado. 
Nesse discurso, Maria e eu fomos ao cinema cria um espaço do passado P a partir de um espaço BASE B, que, nesse momento do discurso, é também PONTO DE VISTA. O espaço P é FOCO. A seguir, a sentença e ela me contou que já tinha assistido o filme e tinha gostado constrói um espaço da fala da Maria F, que passa a ser FOCO, por ser o espaço sendo elaborado. Já que esse espaço é construído a partir do espaço P, P passa a ser PONTO DE VISTA. Neste ponto, temos que tanto eu quanto a Maria estruturam internamente o espaço P, que é PONTO DE VISTA pois é o espaço a partir do qual se elabora o espaço F, da fala. Sendo essa a configuração de espaços nesse pequeno discurso, fica a dúvida sobre quem vê, ou seja de quem é o ponto de vista (do falante/narrador (eu) ou da personagem (Maria)), ou, nos termos de Genette, de que tipo de focalização se trata (narrativa não-focalizada, ou narrativa de focalização interna). .

O PONTO DE VISTA também é explorado nas propostas que se valem da teoria de espaços mentais, feitas por Cutrer (1994) sobre a análise temporal; por Doiz-Bienzobas (1995) sobre a análise do perfectivo e imperfectivo em espanhol; por Tenuta (2006) sobre a análise de narrativas em português brasileiro; e por Tenuta e Lepesqueur (2014) sobre a análise de valores temporais não canônicos de passado em português brasileiro. Nessas análises, o PONTO DE VISTA serve como espaço de referência para construir outros espaços segundo as relações estabelecidas pelas categorias tempo-aspectuais. Nesse sentido, o espaço BASE, que para os autores é sempre presente, serve como referência para a construção de espaços do futuro e do passado, ou seja é o espaço PONTO DE VISTA nessas relações.

Pela minha observação do funcionamento do modelo, gostaria de sugerir que o PONTO DE VISTA no modelo de espaços mentais responde a pergunta: a partir de onde se vê?, e não quem vê?, como é proposto por Genette (1980). Embora em Fauconnier (1997) haja menções ao ponto de vista de personagens, parece-me que o modelo de espaços mentais não tem como objetivo representar os jogos de voz e focalização descritos por Genette (1980). A categoria PONTO DE VISTA no modelo de espaços mentais me parece ser mais uma categoria que permite acompanhar a estrutura do discurso não só de um ponto de vista temporal, como propõem Cutrer (1994), Doiz-Bienzobas (1995), Tenuta (2006) e Tenuta e 
Lepesqueur (2014), mas também de um ponto de vista epistêmico, como fica evidenciado pela construção de espaços hipotéticos, da crença ou contra-sequenciais em Fauconnier $(1997) .^{25}$

Aos três primitivos discursivos BASE, FOCO e PONTO DE VISTA, Cutrer (1994) adiciona o espaço EVENTO. Esse é o espaço em que se constrói a estrutura completa de um evento ou situação. A autora o descreve como um espaço temporal em que se elabora o evento codificado pelo verbo (CUTRER 1994, p.72). Esse espaço é um recurso que a autora traz para lidar com cálculos temporais que, nos termos do modelo de Reichenbach (1974), configuram um mapeamento em que o Tempo de Evento não é concomitante com o Tempo de Referencia, que por sua vez é não concomitante com o Tempo de Enunciação. Reichenbach (1974) propõe que os tempos verbais são calculados por meio de três momentos, o Tempo da Enunciação, o Tempo de Referência e o Tempo do Evento, e as relações de anterioridade, posterioridade e concomitância que se estabelecem entre eles. ${ }^{26}$ Em sentenças como (1) e (2), o Tempo de Enunciação é o momento em que a sentença é proferida; o Tempo de Referência é estabelecido em relação ao Tempo de Enunciação e codificado pelas datas (em 1990, em 2020); e o Tempo de Evento é estabelecido em relação ao Tempo de Referência e expresso pelas formas verbais (tinha ido, terei terminado).

(1) Em 1990 eu já tinha ido para a Europa várias vezes e fui pela primeira vez para a Ásia.

(2) Em 2020 vou começar o Doutorado, pois já terei terminado meu Mestrado .

Na perspectiva da teoria de espaços mentais, as sentenças (1) e (2) - já consideradas como fazendo parte do domínio do espaço da narrativa - se estruturam por meio de (i) um espaço BASE que é também o PONTO DE VISTA; (ii) um espaço construído pelas expressões em 1990, em 2020 - chamadas construtores de espaço (Fauconnier 1994; 1997) - que é o

\footnotetext{
${ }^{25}$ Por questões de tempo e de foco da pesquisa essa discussão não será mais profundamente explorada nessa dissertação, embora mereça ser vista com mais detalhe. As análises apresentadas daqui em diante se encaixam dentro das propostas de Cutrer (1994), Doiz-Bienzobas (1995), Fauconnier (1997), Tenuta (2006), e Tenuta e Lepesqueur (2014) do funcionamento do PONTO DE VISTA dentro do modelo de espaços mentais.

${ }^{26}$ Esse esquema de Reichenbach foi explorado por Benveniste (1966) e por Fiorin (2005).
} 
espaço FOCO ${ }^{27}$ e um espaço EVENTO que é elaborado pelos verbos que descrevem o evento (tinha ido, terei terminado), de maneira que o espaço EVENTO se ancora ao centro dêitico (espaço BASE) por meio do espaço FOCO. Com o intuito de compatibilizar a proposta de construção do tempo no âmbito da teoria de espaços mentais com a teoria de tempo de Reichenbach (1974), sugiro que o espaço FOCO seja entendido como como correlato ao Tempo de Referência. É então a partir do espaço FOCO que é calculado o tempo dos eventos ou as situações do espaço EVENTO. ${ }^{28}$

Na ausência desse primitivo discursivo EVENTO, os cálculos temporais dariam uma leitura equivocada. A Figura 5 apresenta duas possibilidades de análise da construção temporal da sentença (1): em (a), a análise é feita sem o primitivo espaço EVENTO, fazendo uso unicamente do espaço FOCO; em (b) o espaço EVENTO é incluído no cálculo temporal. Em (a) vemos como o construtor de espaço em 1990 cria um espaço FOCO a partir da BASE. Esse espaço E2 é elaborado pelo frame de ir para Ásia, e é FOCO pelo fato de ser o foco primário de atenção, ou seja o espaço sendo elaborado. No entanto, a sentença (1) contém a informação das viagens para Europa que aconteceram num tempo anterior à 1990 . Nesse caso, o uso da forma do pretérito mais-que-perfeito composto (tinha ido) cria um novo espaço E3 que é elaborado pela informação ir para a Europa várias vezes. Com a criação de E3, E2 passa a ser PONTO DE VISTA e E3, FOCO; no entanto, sabemos que a informação relevante da sentença (1) é a viagem para Ásia e que a informação codificada em já tinha ido para Europa várias vezes é informação que serve para contextualizar o evento principal. Como o espaço FOCO é aquele de que trata um enunciado, no caso em questão a ativação está na viagem à Ásia em 1990, e não nas viagens anteriores à Europa. ${ }^{29}$

\footnotetext{
${ }^{27}$ Abaixo tratarei mais detalhadamente dos construtores de espaço.

${ }^{28}$ Lembro que todos esses espaços, para os fins desta dissertação, estão ancorados no primeiro centro dêitico que é o espaço da enunciação.

[isto é outra nota? Se não, por que não tá seguindo a nota 24; se sim, por que não tem número?] Essa relação entre espaço FOCO e Tempo de Referência vai ficar mais clara, e, espero, justificada, pela análise de uma pequena narrativa que vem mais adiante. Essa relação vai ter também o mérito de explicar as diferentes estratégias de construção de novos espaços mentais, algumas feitas por advérbios de tempo ou sintagmas preposicionados (ontem, em 1990, etc.) e morfemas temporais que participam da flexão verbal.

${ }^{29}$ A autora usa a expressão em inglês to be about something, que eu escolhi traduzir como se tratar de algo em português. $\mathrm{O}$ fragmento original diz: "The FOCUS space is the space where meaning is
} 
$\mathrm{O}$ esquema (a) da Figura 5 mostra o que aconteceria na falta do espaço EVENTO: dois espaços FOCO precisariam ser criados e estar disponíveis simultaneamente: o espaço E2 por corresponder àquilo de que trata o enunciado, e o espaço E3 por ser o espaço sendo elaborado no momento do discurso. O problema com essa opção é que ela quebra um princípio do modelo, chamado Princípio Discursivo Geral no. 1, segundo o qual "a qualquer momento no processo de interpretação do discurso pode haver somente um espaço FOCO” (CUTRER 1994, p.77).

Já o esquema (b) apresenta a análise da mesma sentença (1) com a inclusão do espaço EVENTO. O pretérito mais-que-perfeito composto gera um espaço EVENTO, filho do espaço FOCO, que continua a ser aquele elaborado pelo evento principal do enunciado (a viagem à Ásia). Outra pista que existe para identificar o espaço FOCO e diferenciá-lo do espaço EVENTO é que espaços FOCO costumam ser construídos por adverbiais que indicam uma referência temporal específica (CUTRER 1994, p.71); tal é o caso de em 1990 e em 2020. Assim, o espaço FOCO é filho do espaço BASE, sendo também o espaço do Tempo de Referência para o cálculo do espaço EVENTO; e como o espaço EVENTO é filho de FOCO, este funciona, por sua vez, como Tempo de Referência para o cálculo do espaço EVENTO. No esquema (b), não há violação do Princípio Discursivo Geral no. 1 proposto por Cutrer, nem se ampliam as características do espaço FOCO. ${ }^{30}$

currently being constructed. It is the current most active space; the space which an utterance is 'about"' (grifos meus) (CUTRER 1994, p.71).

${ }^{30}$ Existem outros Princípios de Organização Discursiva, dos quais tratarei logo abaixo. 


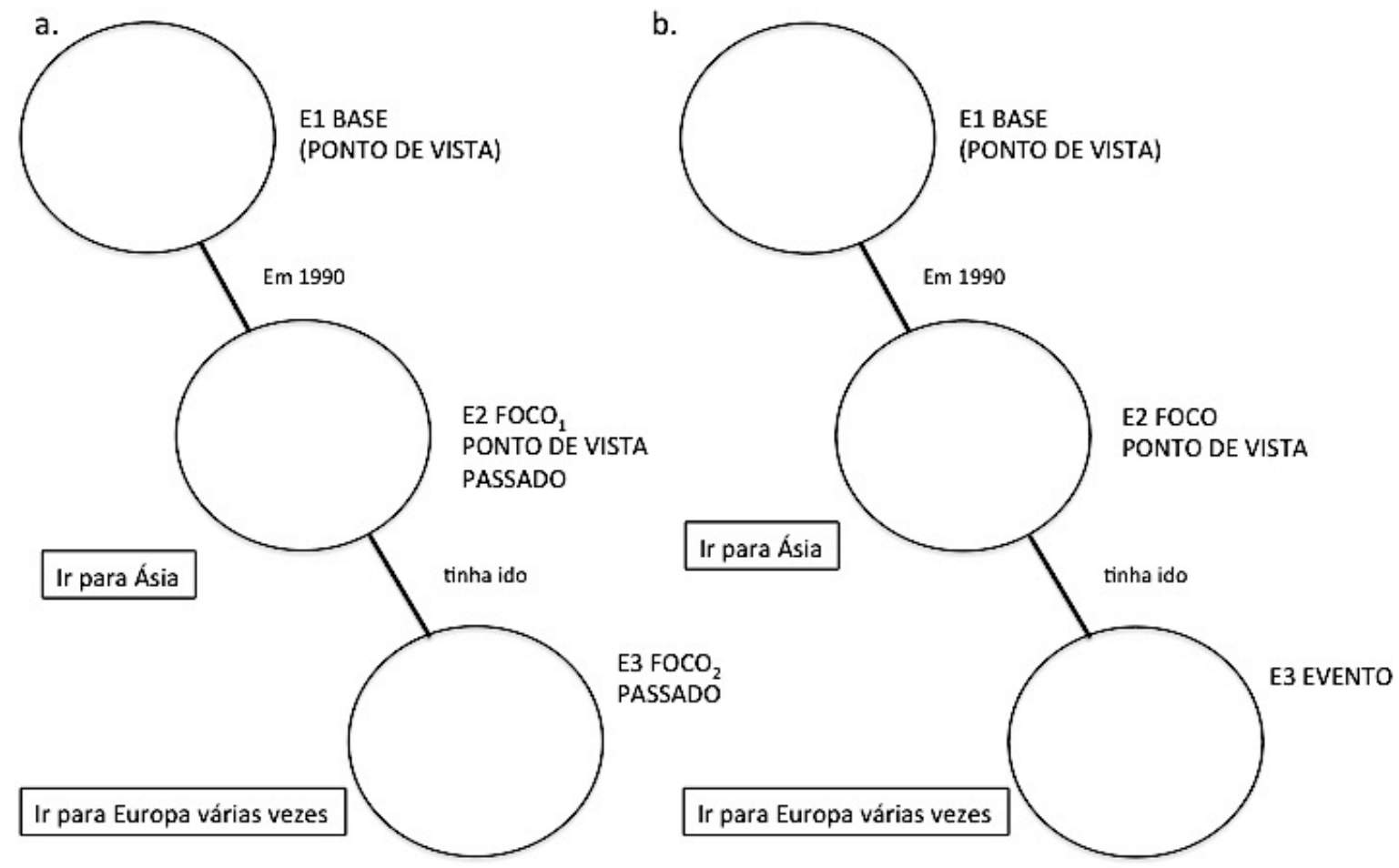

Figura 5 Cálculos temporais do espaço EVENTO. (a) na ausência do espaço EVENTO; (b) com o espaço EVENTO.

Como visto anteriormente, os primitivos discursivos não se excluem mutuamente, de maneira que podemos ter um espaço que seja ao mesmo tempo BASE, PONTO DE VISTA, FOCO e EVENTO; BASE e PONTO DE VISTA; ou somente BASE, FOCO, EVENTO ou PONTO DE VISTA. Segundo Fauconnier (1997), no começo de qualquer discurso, o espaço BASE é sempre o primeiro PONTO DE VISTA, pois é o espaço da perspectiva do qual se constróem outros espaços mentais; no entanto, como já dito, isso só pode ser mantido quando se omite o espaço da enunciação (EE), onde estão o enunciador e o enunciatário de carne e osso no aqui e agora da interação. Uma vez que nesta pesquisa eu adoto a proposta de McCleary e Viotti (2014) de criação do espaço BASE a partir do espaço do narrador EN, que por sua vez é criado a partir da integração dos espaços da enunciação (EE) e do frame de narração (EFN), a partir de agora se tem que o primeiro PONTO DE VISTA é sempre EE. Esses espaços primitivos são organizados, distribuídos e redistribuídos dinamicamente nas redes de espaços por uma série de Princípios de Organização Discursiva, que serão apresentados com os exemplos de análise mais adiante. 
Além dos Princípios de Organização Discursiva que organizam as relações entre espaços, construtores de espaços indicam que um novo espaço vai ser construído, ou que o foco de atenção deve se voltar para algum espaço já presente na rede. Os construtores de espaços são codificados por sintagmas preposicionais (em 1929..., na história..., na verdade...); advérbios (anteriormente..., ontem..., mais cedo...); construções de sujeito-verbo (Maria acha..., João espera..., Pedro acredita...); e sentenças introduzidas por conjunção (se chover amanhã...) (FAUCONNIER 1997, p.40). ${ }^{31}$

Cada espaço mental se estrutura internamente por frames associados a nomes (Juliana, Napoleão, Pina Bausch, etc.) e descrições (o gato, um cachorro bravo, as crianças que jogam futebol na rua, etc.) que apontam para novos elementos dentro de um espaço; para elementos já existentes na rede de espaços; e para eventos ou situações (ver, correr, ser, etc.) que configuram também a informação contida dentro de cada espaço. Os frames, como propostos por Fillmore, contêm a informação de fundo que inclui os componentes essenciais e os acompanhamentos de qualquer definição de uma palavra (FILLMORE 2003, p.263). Isso quer dizer que, por exemplo, o frame de cachorro inclui as coisas que consideramos mais genéricas de cachorro (mamífero, peludo, de quatro patas, canino, doméstico, etc.) mas também tudo o que um falante tenha associado à noção de cachorro durante a sua vida. Frames podem ser tão amplos quanto for necessário para um falante num evento específico de comunicação e, ao mesmo tempo, podem não ser acessados na totalidade de suas informações se o evento comunicativo não o exigir. Segundo Fillmore (2003, p.272), cada vez que usamos uma palavra, evocamos um frame e ressaltamos um aspecto dentro dele. Ele dá, como exemplo, a compreensão dos conceitos psicanalíticos de $i d$, ego e superego, que dependem do conhecimento do elaborado complexo de ideias desenvolvidas na teoria de Freud (FILLMORE 2003, p.273). Para qualquer pessoa que tente entender esses conceitos, vai ser necessário o conhecimento de toda a rede de ideias

\footnotetext{
${ }^{31}$ Fauconnier (1994, p.40) apresenta os construtores de espaços como fazendo parte dessas categorias gramaticais em general; no entanto, não são todos os advérbios, frases preposicionais, construções de sujeito-verbo, e sentenças introduzidas por conjunção que funcionam como construtores de espaço.. Cutrer aumenta a lista de possíveis construtores de espaços com marcas gramaticais de tempo e modo, e inclusive pistas pragmáticas, que podem construir novos espaços na ausência de marcas gramaticais (CUTRER 1994, p.50). No entanto, nenhum dos dois autores discute a natureza semântica desses construtores de espaços mentais [Não entendo direito o que vc esperaria que eles discutissem sobre a natureza semântica dos construtores].
} 
que unem esses conceitos entre si, e com outros aspectos relevantes da teoria psicanalítica. No modelo de espaços mentais, cada vez que incluímos um evento ou uma descrição ou nome próprio num espaço mental incluímos informação de fundo sobre qualquer um deles sobre as ações ou situações em que elas estão envolvidas. Os espaços mentais são então elaborados internamente por essa informação de fundo associada a todos e cada um dos elementos que façam parte deles.

Os nomes e descrições têm outro papel fundamental na construção de redes de espaços e na elaboração interna dos espaços mentais no discurso. Esse papel tem a ver com o Princípio de Identificação que estabelece que uma expressão que dá nome ou descreve um elemento em um espaço mental pode ser utilizada para acessar sua contraparte em outro espaço mental. Isso quer dizer que, se um elemento (a) em um espaço E está ligado por um conector F a um elemento (a') em um espaço E', então (a') pode ser identificado, a cada nomeação, descrição ou apontamento, com a sua contraparte (a) (FAUCONNIER 1997, p.41).

A dinâmica de construção de espaços, a sua elaboração interna a partir de frames e o Princípio de Identificação serão descritos a partir da esquematização da seguinte história, criada aqui também para introduzir as categorias temporais propostas por Cutrer (1994): ${ }^{32}$

(3) Maria está falando com os pais.

(4) Ela decidiu sair de casa e vai alugar um apartamento.

(5) Ontem ela telefonou para um corretor, que tinha sido recomendado por uma amiga.

(6) Ela estava ansiosa.

(7) Ela ligaria para ele até o fim do dia.

(8) No mês que vem, ela já vai ter alugado o apartamento, vai se mudar, e depois disso vai adotar um gato.

(9) Ela espera que tudo dê certo.

\footnotetext{
${ }^{32}$ A história da Maria é narrada de (3) a (9). Optei por numerar os trechos separadamente para facilitar a referência no corpo do texto.
} 
A Figura 6 apresenta o mapeamento de toda a historinha da Maria. A dinamicidade dos papeis de BASE, FOCO, EVENTO e PONTO DE VISTA é esquematizada a partir de parênteses, que aparecem nos elementos que vão se mover ao longo da construção dos espaços na narrativa, seguindo o formato adotado por Tenuta (2006). Pode ser visto que o único espaço que não se movimenta na rede de espaços nesta história é o espaço BASE, que é sempre o espaço E1, pois é o primeiro espaço criado pelo narrador para começar a história. No entanto, é possível achar narrativas com diferentes espaços BASE que estão ativos em diferentes momentos da narração. Cutrer (1994) afirma que o espaço BASE é um espaço presente, por default; no entanto isso deverá ser discutido mais adiante na dissertação, pois é possível (além de comum) haver histórias que começam com um espaço passado (Era uma vez..., No século XIX..., Antigamente...). No caso da narrativa entre (3) e (9) acima, ele é de fato um espaço presente. Na parte superior dos mapeamentos da história da Maria aparecerá sempre o esquema da integração conceitual da qual surge o espaço do narrador (EN), que por sua vez é pai do espaço BASE. A Figura 7 mostra a elaboração interna de cada espaço mental presente na Figura 7. 


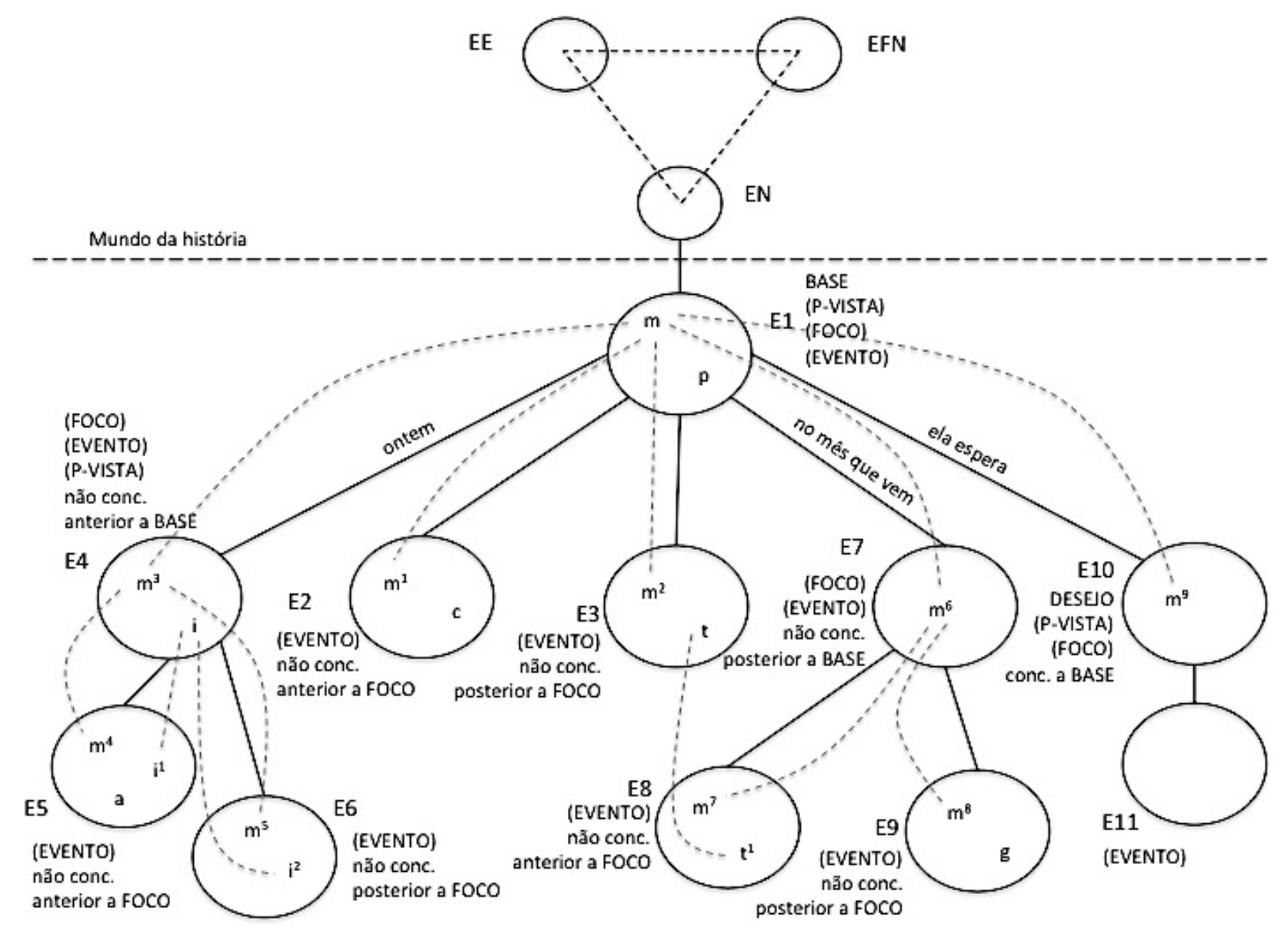

Figura 6 Rede de espaços mentais completa para a historinha da Maria.

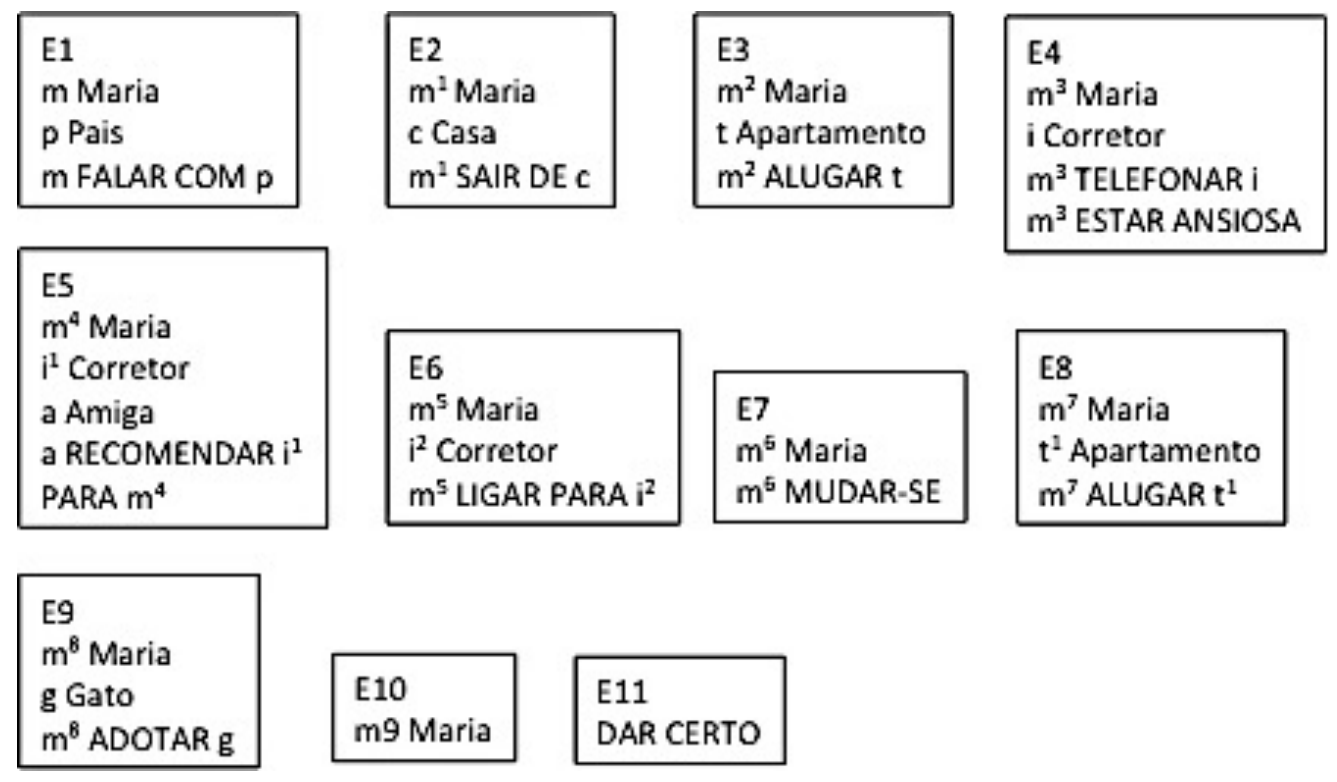

Figura 7 Elaboração interna dos espaços mentais apresentados na Figura 4. 
A Figura 8 apresenta o mapeamento de espaços mentais das sentenças (3) e (4). O nome próprio Maria no enunciado (3) (Maria está falando com os pais.) introduz o elemento $m$ no espaço E1. A descrição os pais, por sua parte, introduz o elemento $p$. O frame que estrutura este espaço E1 é o de FALAR, com $m$ como quem fala e $p$ como com quem se fala. Nesse primeiro momento o espaço E1 é BASE, PONTO DE VISTA, FOCO e EVENTO; ele é um evento presente que é elaborado por um verbo na forma progressiva (está falando).

Neste ponto vale a pena determo-nos em como a teoria de espaços mentais lida com noções temporais e aspectuais. Quando se fala de tempo nessa teoria, fala-se de tempo relativo, pois as marcas gramaticais de temporalidade relacionam eventos no interior de um mapeamento específico de espaços mentais (FAUCONNIER 1997, p.72). Esse mapeamento se organiza por categorias tempo-aspectuais, que têm a função de fazer ligações locais parciais entre espaços; essas categorias são: PRESENTE, PASSADO, FUTURO, PROGRESSIVO, PERFEITO, IMPERFECTIVO e PERFECTIVO (CUTRER 1994, p.87) e seu comportamento é descrito por Cutrer (1994) por meio de uma série de princípios de organização discursiva. ${ }^{33}$ Para Fauconnier, elas são noções discursivas, em oposição aos marcadores gramaticais de tempo nas línguas, que são noções gramaticais. Cutrer vai além dessa definição e afirma que essas noções discursivas (as instruções parciais para a construção cognitiva no discurso) são tipos universais de ligações entre espaços mentais (CUTRER 1994, p.22). As línguas têm diferentes mecanismos para marcar essas categorias discursivas tempo-aspectuais, sendo que um marcador gramatical de tempo pode expressar uma dessas categorias ou uma mistura delas; no entanto, a relação não é necessariamente de um marcador gramatical para cada categoria discursiva. Por exemplo, em inglês, o Futuro do Passado (would freeze) é uma combinação das categorias discursivas PASSADO FUTURO (CUTRER 1994, p.120); já o Presente Simples dessa língua expressa a categoria discursiva de PRESENTE. ${ }^{34}$

\footnotetext{
${ }^{33}$ Aqui optei por mencionar esses princípios conforme foi necessário para a análise da historinha da María. Suas características foram numeradas com números romanos (i-x) para facilitar a referência posteriormente.

${ }^{34}$ Ao longo da dissertação utilizarei a convenção usada por Cutrer (1994) para me referir à noções tempo-aspectuais. Maiúsculas serão utilizadas para falar das categorias discursivas tempoaspectuais (PRESENTE, PASSADO, FUTURO, PROGRESSIVO, PERFEITO, IMPERFECTIVO e PERFECTIVO), maiúscula inicial para falar de categorias temporais gramaticais (Passado Simples,
} 


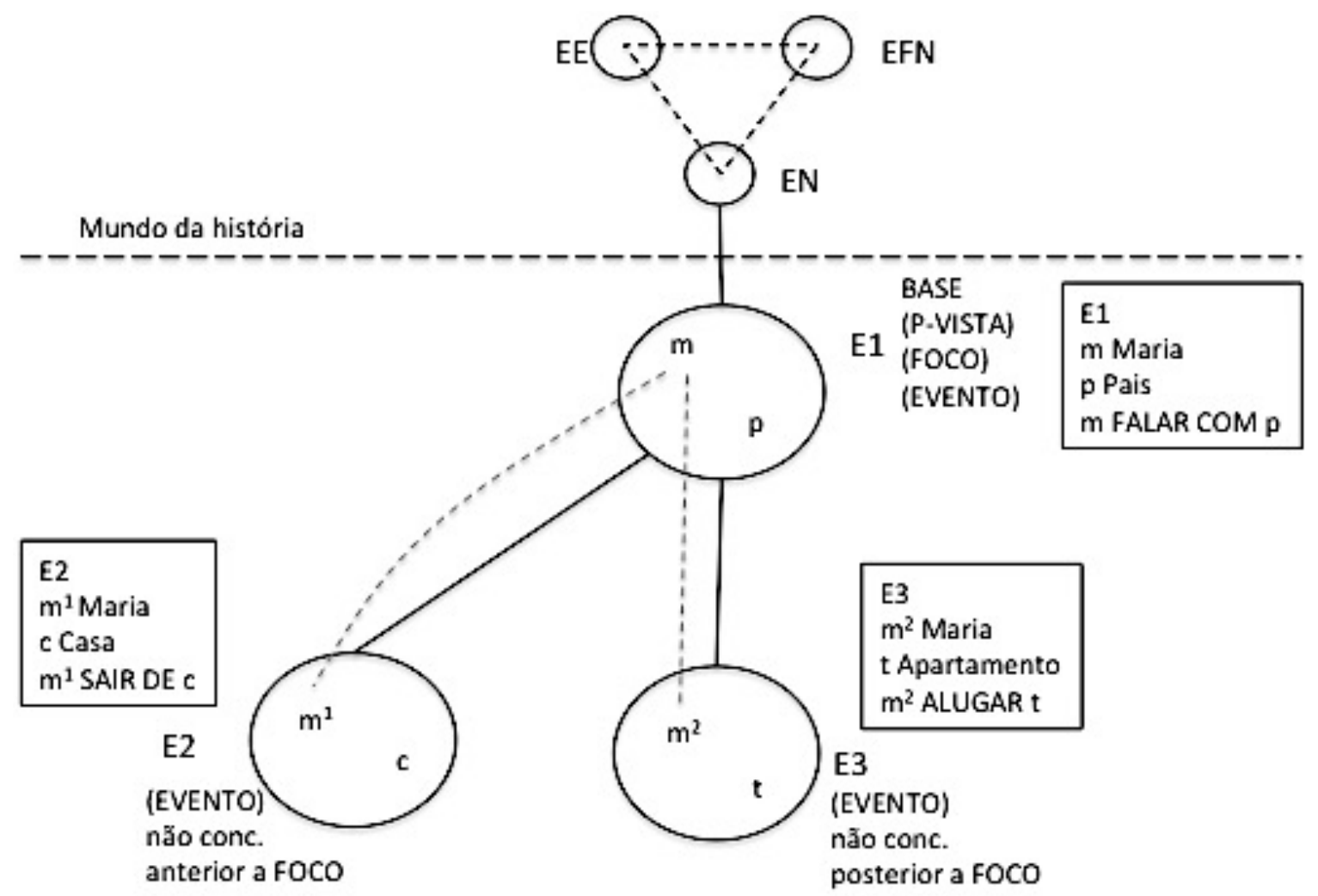

Figura 8 Mapeamento de espaços mentais: sentenças (3) e (4).

Voltando à análise do enunciado (3), e tendo em consideração as categorias tempoaspectuais propostas por Cutrer (1994), temos que o Presente Progressivo (está falando) cria um mapeamento de espaços mentais a partir das categorias PRESENTE e IMPERFECTIVO. ${ }^{35}$ PRESENTE indica que:

Futuro do Passado, Pretérito Perfeito, etc.), e minúsculas para falar de noções temporais não linguísticas (futuro, passado, presente, etc.)

${ }^{35}$ Nesse ponto seria possível perguntar por quê não uso a categoria PROGRESSIVO proposta por Cutrer (1994), pois parece ser a indicada no caso do Presente Progressivo. Escolhi optar por restringir as categorias tempo-aspectuais a cinco: PRESENTE, PASSADO, FUTURO, PERFECTIVO e IMPERFECTIVO, pois me parece que condensam a informação necessária em se tratando de análise de movimento de BASE, FOCO, PONTO DE VISTA e EVENTO. A categoria PROGRESSIVO proposta por Cutrer $(1994$, p. 92) dita que (i) o espaço Ex não é FOCO; (ii) o pai do espaço Ex é P-VISTA; e (iii) o lapso de tempo representado em Ex inclui P-VISTA, ou PVISTA ocorre durante Ex. No entanto, IMPERFECTIVO indica que FOCO ou EVENTO e P- 
i) E1 é FOCO.

ii) E1, ou o pai de E1 (no caso EN), é PONTO DE VISTA.

iii) O tempo representado em E1 não é anterior a PONTO DE VISTA ou BASE.

iv) Eventos ou propriedades representados em E1 são caracterizados como FATO (Cutrer 1994). ${ }^{36}$

Neste ponto de narrativa, o espaço E1 é tanto FOCO, ou seja o espaço que determina o Tempo de Referência para fazer o cálculo temporal dos eventos, quanto EVENTO. O tempo do evento (falar) é concomitante ao Tempo de Referência.

Por outro lado, IMPERFECTIVO indica que o espaço E1 é PONTO DE VISTA. Essa característica implica que os eventos descritos no espaço são conceitualizados de uma perspectiva interna a eles, que não permite ver neles nem começo nem fim; já quando o PONTO DE VISTA é externo ao evento, este pode ser visto como tendo limites. Imagine estar voando para uma ilha; quando o avião começa a descer e se aproximar da ilha você pode vê-la inteira, as praias que a rodeiam e chegam no mar; depois, quando o avião pousa você não consegue ver mais a ilha; talvez consiga ver uma praia e um pouco do mar, mas estando na ilha, ver todos os seus limites é impossível. O aspecto IMPERFECTIVO é como estar na ilha, já o PERFECTIVO é como estar no avião.

VISTA são o mesmo espaço, o que já resolve o problema de eles acontecerem no mesmo lapso temporal, e elimina a necessidade de incluir informação complementar na descrição dos espaços, como P-VISTA ocorre durante Ex. Já o fato de Ex ser ou não FOCO (ver (i)) vai depender, nessa dissertação, de se o espaço pode ser tomado como Tempo de Referência em termos de Reichenbach (1974) ou como Tempo de Evento.

${ }^{36}$ Para Cutrer (1994) o espaço E1 não é BASE, só FOCO e PONTO DE VISTA, pois o espaço BASE seria o pai de E1. Neste trabalho o espaço E1 é tratado como BASE, por ser o espaço pelo qual começa a narrativa; talvez em narrativas que começam com tempos não concomitantes com o tempo da enunciação, seja necessário separar o espaço BASE do primeiro espaço na narrativa, mas como não é o caso aqui, o espaço PRESENTE E1 é também BASE. [Notas não podem ter parágrafo. Coloque o resto aqui]

Cutrer (1994) propõe também uma outra consequência do tratamento do tempo na teoria de espaços mentais, que é a característica de que os eventos e propriedades podem ser caracterizados como FATO ou PREVISÃO vistos de um espaço PONTO DE VISTA. Para a autora, eventos do presente ou do passado são considerados FATOS, pelo fato de serem verificáveis, já os eventos ou propriedades do futuro podem ser só PREVISÕES, pois não há como verificar sua existência/ocorrência. 
Doiz-Bienzobas (1995) estudou a diferença de PERFECTIVO e IMPERFECTIVO em espanhol, e afirma que a diferença entre os dois é que o IMPERFECTIVO evoca um ponto de vista passado, enquanto o PERFECTIVO evoca um ponto de vista presente. A autora afirma que quando formas imperfectivas são usadas, falantes nativos de espanhol interpretam os enunciados como tendo uma coincidência entre o evento $\mathrm{e} a$ conceitualização do evento. A autora chama o efeito obtido do uso de formas de perfectivo (especificamente o Pretérito Perfecto do espanhol) de self narrador, e aquele evocado pelo imperfectivo (Pretérito Perfecto do espanhol) de self experienciador. A autora também propõe que esse self narrador seja identificado com o ponto de vista do narrador, e que o self experienciador indica um ponto de vista passado que pode ou não ser do narrador/enunciador (DOIZ-BIENZOBAS 1995, p.57). ${ }^{37}$

No enunciado (4) (Ela decidiu sair de casa e vai alugar um apartamento.), temos duas formas verbais (decidiu, vai alugar) cujos tempos não são concomitantes com o tempo do espaço BASE, pelo que não podem estruturar o espaço E1, e devem criar espaços temporais novos. No entanto, tampouco aparece no enunciado qualquer construtor de espaço mental, ou seja um marcador adverbial de tempo, no caso. Essas formas verbais constróem, então, dois espaços temporais, E2 e E3 respectivamente, que são caracterizados como EVENTO, e que são filhos do espaço FOCO. O espaço E2 é um espaço PASSADO, cujo Tempo de Referência é o PRESENTE do espaço E1 FOCO; já o espaço E3 é um espaço FUTURO filho do mesmo espaço E1 FOCO.

$\mathrm{O}$ espaço E2 é elaborado internamente pelo nome próprio Maria e a descrição casa. $\mathrm{O}$ nome Maria faz referência a um elemento $m$ no espaço E1, mas o elemento $m$ permanece no espaço E1 que continua ativo e disponível durante a narração. Aqui age o Princípio de

\footnotetext{
${ }^{37}$ Embora em Doiz-Bienzobas (1995) o papel do narrador seja destacado e haja uma análise da relação de uso de formas perfectivas ou formas imperfectivas associada à voz e perspectiva desse narrador, não há nenhuma discussão sobre o que seria o ponto de vista das personagens. A noção de self experienciador poderia resolver essa questão, pois como propõe a autora se trata de um ponto de vista que pode ou não ser do narrador/enunciador, o que significa que pode ou não ser de uma personagem. Essa pesquisa não pretende resolver esse problema, mas acredito que seja importante ressaltar a limitação que a noção de PONTO DE VISTA tem nesse aspecto [troque a palavra, porque aspecto é um termo técnico que pode levar a confusão aqui].
} 
Identificação, que estabelece que uma expressão que dá nome ou descreve um elemento em um espaço mental pode ser utilizada para acessar sua contraparte em outro espaço mental, de forma que $m^{l}$ em E2 é a contraparte de $m$ no espaço E1, e isso é indicado no diagrama pelas linhas cinzas pontilhadas. ${ }^{38} \mathrm{O}$ espaço E2 é elaborado internamente pelo frame de SAIR DE com $m^{l}$ com o papel de quem sai e $c$ com o papel de onde se sai.

E2 é um espaço não concomitante com o espaço E1, FOCO, que é seu pai, e essa nãoconcomitância se dá em termos de anterioridade ao Tempo de Referência. Nesta nova configuração de espaços, o espaço E2 é EVENTO, enquanto o espaço E1 permanece FOCO (Tempo de Referência), PONTO DE VISTA e BASE. Esse é um espaço caracterizado pelas categorias tempo-aspectuais PASSADO e PERFECTIVO. PASSADO indica que:

v) E2 é EVENTO ou FOCO.

vi) Se E2 for EVENTO, o pai de E2 (E1 no caso) é FOCO. Se for FOCO o espaço pai é BASE.

vii) Se for EVENTO, o tempo de E2 é anterior ao de FOCO. Se for FOCO o tempo de E2 é anterior ao de BASE.

Já PERFECTIVO indica que:

viii) E2 não é PONTO DE VISTA.

Como exposto acima IMPERFECTIVO em contraposição indicaria que:

ix) O espaço FOCO não é PONTO DE VISTA.

\footnotetext{
${ }^{38}$ Tanto Cutrer (1994) quanto Fauconnier (1997) sinalizam as contrapartes dos elementos nos espaços com aspas simples ( $m$ ', $m$ ', $m$ ','), no entanto, por conta da quantidade de elementos que podem se identificar em uma mapeamento de espaços como a historinha da Maria, preferi marcá-los com números superordenados.
} 
Voltando à analogia da ilha, o PERFECTIVO indica que os eventos e propriedades caracterizados em E2 são conceitualizados como sendo observados de fora, a partir do avião, o que implica vê-los como completos.

A segunda parte do enunciado (4) (e vai alugar um apartamento) cria um espaço temporal E3, que é elaborado internamente pelos elementos $m^{2}$ Maria, $t$ um apartamento, e o frame de ALUGAR com $m^{2}$ como quem aluga e $t$ como o que é alugado. Esse espaço é um espaço EVENTO e FUTURO. FUTURO indica que:

x) E3 é EVENTO ou FOCO.

xi) Se E3 for EVENTO, o pai de E3 (E1 no caso) é FOCO.

xii) Se for EVENTO, o tempo de E3 é posterior ao de FOCO. Se for FOCO o tempo de E2 é posterior ao de BASE.

Os espaços E2 e E3 são filhos do espaço FOCO E1, o que indica que são espaços EVENTO; o tempo de E2 e E3 é calculado a partir do tempo do espaço FOCO que é concomitante ao tempo do espaço BASE, que por sua vez é concomitante ao tempo do espaço EN, que é concomitante ao tempo da enunciação. E2 pode ser caracterizado como sendo um espaço Passado do Presente, e E3 como sendo Futuro do Presente.

A Figura 9 mostra o mapeamento de espaços mentais dos enunciados:

(5) Ontem ela telefonou para um corretor, que tinha sido recomendado por uma amiga.

(6) Ela estava ansiosa.

(7) Ela ligaria para ele até o fim do dia.

O primeiro enunciado contém o construtor de espaço ontem que cria um espaço FOCO E4. O espaço criado é FOCO pois é o espaço que está sendo elaborado no momento (Cutrer 1994, Fauconnier 1997); na análise aqui proposta, E4 é também FOCO por se tratar de um espaço Tempo de Referência que, no caso, é não concomitante ao tempo do espaço BASE, que por sua parte é concomitante ao tempo do espaço EN, que por sua vez é concomitante 
ao Tempo da Enunciação. Sabemos disso porque o enunciado contem o advérbio ontem, que, por ser um construtor de espaços mentais, cria um novo espaço mental, que no caso é FOCO, pois ontem coloca o Tempo de Referência fora do espaço BASE. Esse espaço E4 é um espaço mental que tem as características das categorias tempo-aspectuais de PASSADO e PERFECTIVO, o que indica que tem as mesmas características de organização local que o espaço E2 na Figura 9. No caso específico, PASSADO indica que:

v) E4 é FOCO.

vi) Se E4 for FOCO, o pai de E4 (E1 no caso) é BASE.

viii) Se for FOCO o tempo de E4 é anterior ao de BASE.

Além disso, E4 é PERFECTIVO, o que coloca o PONTO DE VISTA fora dele, e no caso da Figura 9, na BASE E1. E4 é elaborado internamente pelo frame de TELEFONAR com um elemento $\mathrm{m}^{3}$, Maria, como quem telefona e $i$, um corretor, como a pessoa para que $\mathrm{m}^{3}$ telefonou. O elemento $m^{3}$ em E4 se identifica com o elemento $m$ em E1 pelo uso do pronome pessoal anafórico ela na sentença (5).

A segunda parte do enunciado (que tinha sido recomendado por uma amiga), cria um espaço temporal E5 EVENTO, que pela forma no Pretérito Mais-que-perfeito Composto (tinha sido) é não concomitante ao espaço FOCO, e essa relação de não-concomitância se dá em termos de anterioridade. Temos então, que E5 é um espaço Passado do Passado, pois é filho do espaço FOCO E4, que é construído pela categoria tempo-aspectual PASSADO, e ele mesmo, por sua vez, também é construído pelas categorias PASSADO e PERFECTIVO. Além disso, E5 é elaborado internamente pelos elementos $m^{4}$, Maria; $i^{l}, o$ corretor; e a, uma amiga, e pelo frame de RECOMENDAR PARA, com a como quem recomenda, $i^{l}$ como o que se recomenda, e $m^{4}$ para quem se recomenda. 


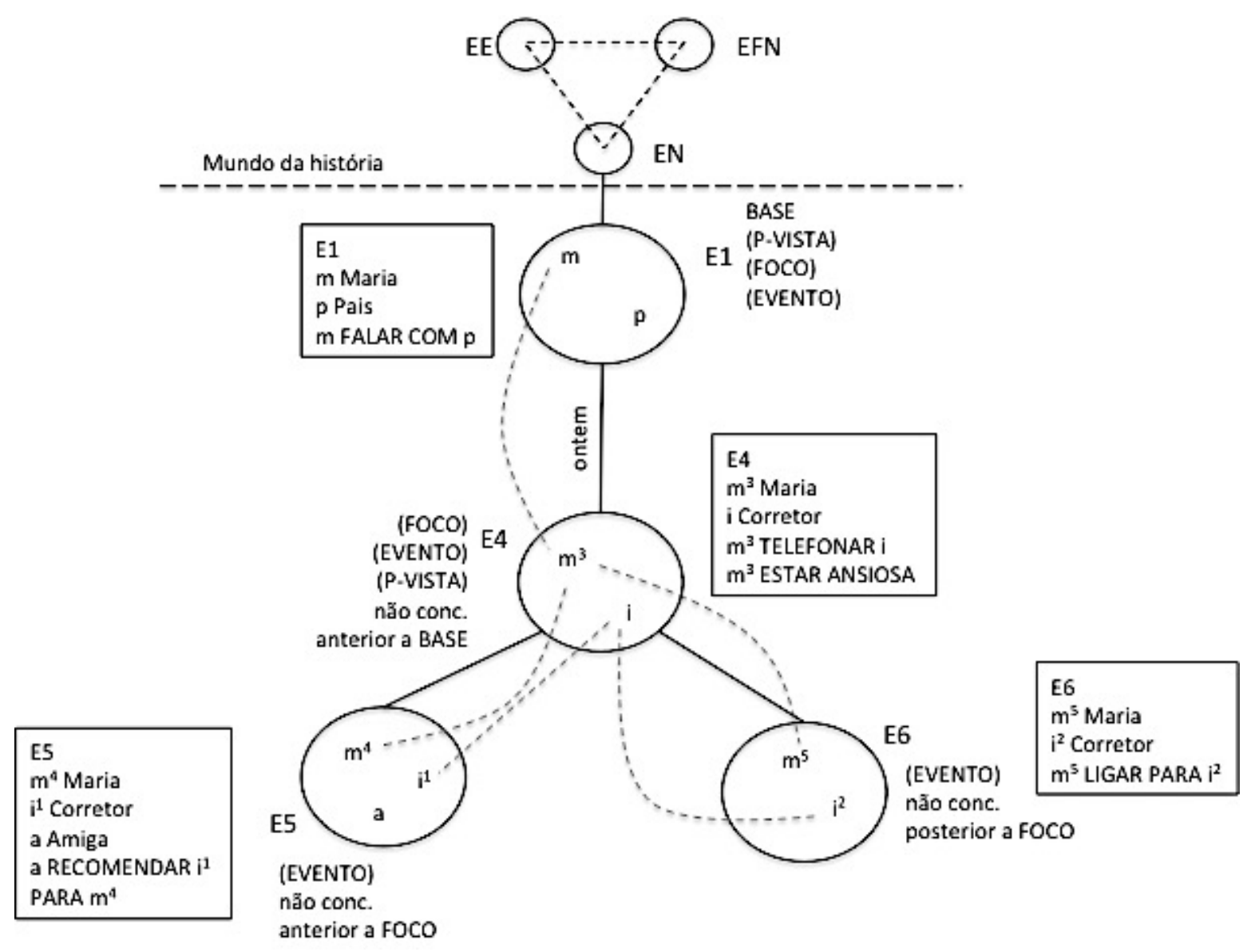

Figura 9 Mapeamento de espaços mentais: sentenças (5), (6) e (7).

A historinha continua assim:

(6) Ela estava ansiosa.

O tempo em que ela estava ansiosa se refere a ontem, pelo que a informação do enunciado (6) retoma o espaço E4 e continua a elaborá-lo. No frame de E4 vemos que se inclui a informação $\mathrm{m}^{3}$ ESTAR ANSIOSA. No entanto, o espaço E4 era um espaço PERFECTIVO, e a forma verbal de Pretérito Imperfeito (estava ansiosa) é uma forma IMPERFECTIVA. Além de elaborar mais o espaço E4, essa forma verbal cria um movimento do PONTO DE VISTA, pois o evento de estar ansiosa se conceitualiza a partir de uma perspectiva interna. PONTO DE VISTA passa do espaço BASE E1 ao espaço FOCO E4, pois é nele que o evento de estar ansiosa acontece. 
O enunciado (7), por sua parte, cria um espaço temporal E6, cuja categoria tempo-aspectual é FUTURO, que no caso indica que:

x) E6 é EVENTO.

xi) Se E6 for EVENTO, o pai de E6 (E4 no caso) é FOCO.

xii) Se for EVENTO, o tempo de E6 é posterior ao de FOCO.

O tempo do espaço E6 é calculado com o tempo de FOCO (E4) como Tempo de Referência, o que indica que o espaço E6 é um espaço Futuro do Passado, pois o Tempo de Referência (espaço FOCO) é não concomitante e anterior ao tempo do espaço BASE, que por sua vez é concomitante ao tempo do espaço do narrador (EN), que é concomitante ao Tempo de Enunciação (do espaço EE), e o Tempo de Evento (espaço EVENTO) é não concomitante posterior ao Tempo de Referência. ${ }^{39}$

O espaço E6 se estrutura internamente com os elementos $m^{5}$, ela, e $i^{2}$, ele, que pelo Princípio de Identificação servem para acessar suas contrapartes: $m^{3}$ Maria, e $i$, o corretor, no espaço E4, respectivamente.

A história continua com o seguinte enunciado:

(8) No mês que vem, ela já vai ter alugado o apartamento, vai se mudar, e depois disso vai adotar um gato.

A Figura 10 mostra o mapeamento de espaços mentais dessa sentença. O construtor de espaço mental no mês que vem cria um espaço FOCO E7 que é elaborado internamente pelo elemento $m^{6}$, ela, que acessa sua contraparte $m$, Maria, no espaço BASE, pelo Princípio de Identificação. O frame que estrutura o espaço é o de MUDAR-SE e $m^{6}$ tem o papel de quem se muda. O espaço E7 é não concomitante ao espaço BASE, e a não concomitância se dá em termos de posterioridade, pois o marcador temporal no mês que

\footnotetext{
${ }^{39}$ No caso dessa historinha em particular o espaço BASE é concomitante com o Tempo da Enunciação, que é o tempo real na interação face-a-face no qual se conta a história. No entanto, o espaço BASE não é o Espaço da Enunciação (EE), e sim o espaço que inaugura a história.
} 
vem indica um tempo futuro em relação ao espaço BASE. Em um primeiro momento, o espaço E7 é tanto FOCO como EVENTO, pois o evento de se-mudar acontece concomitantemente ao Tempo de Referência.

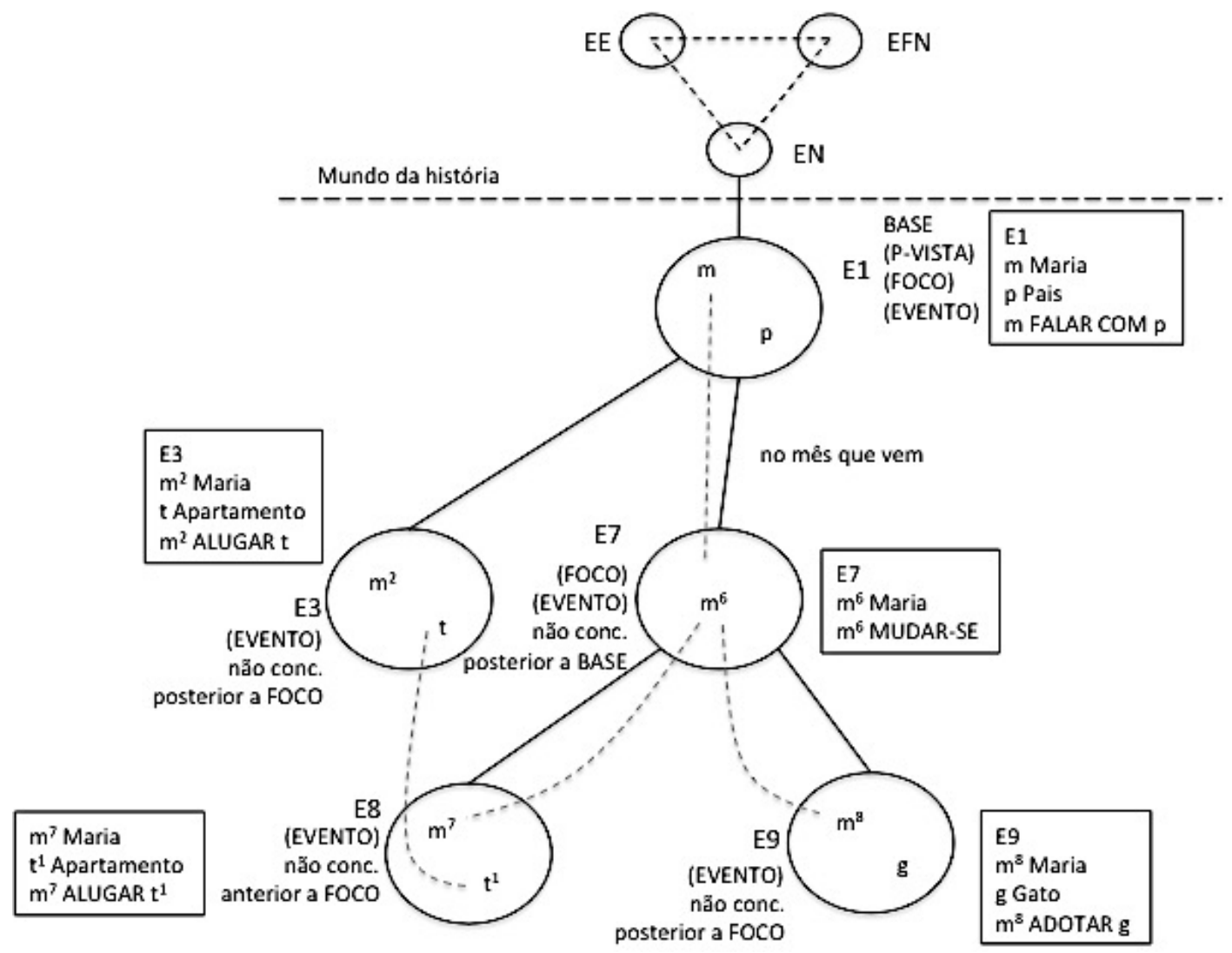

Figura 10 Mapeamento de espaços mentais: sentença (8)

A segunda parte do enunciado (ela já vai ter alugado o apartamento) cria um espaço temporal E8, que está numa relação de não concomitância e anterioridade com o espaço FOCO. A anterioridade é marcada pela forma do Futuro do Presente Composto (vai ter alugado). Este espaço se organiza na rede de espaços segundo as categorias de PASSADO e PERFECTIVO. PASSADO indica que:

v) E8 é EVENTO.

vi) Se E8 for EVENTO, o pai de E8 (E7 no caso) é FOCO.

vii) Se for EVENTO, o tempo de E8 é anterior ao de FOCO. 
O espaço E8 é PERFECTIVO, o que indica que o PONTO DE VISTA está fora dele, no caso, no espaço E1 BASE. Esse espaço é elaborado internamente pelo frame de ALUGAR com $m^{7}$, Maria, como quem aluga, e $t^{l}$, o apartamento, como o que é alugado. Aqui é importante entender o funcionamento do Princípio de Identificação. Como mostra a Figura 10, os elementos que se identificam entre espaços não precisam estar em espaços conectados diretamente. Isso quer dizer que, como na Figura 10, um elemento em E8 pode se identificar com um elemento no espaço E3, sem que exista uma contraparte do elemento nos espaços que ligam um espaço e o outro, no caso os espaços E1 e E7. Isso é assim porque, conforme avança o discurso, os espaços que vão sendo criados ficam semiativos e disponíveis para o acesso em qualquer outro momento do discurso; então, sempre que um elemento tenha aparecido no decorrer do discurso, ele pode ser acessado a partir de outro espaço sem ter que ser o espaço imediatamente anterior.

O espaço E9 é criado pelo enunciado e depois disso vai adotar um gato, cujo verbo está na forma perifrástica do Futuro Simples; no entanto, a frase começa com e depois disso (mudar-se), o que já coloca a informação temporal em um espaço subordinado ao espaço E7. O espaço E9 é, então, um espaço temporal Futuro do Futuro. O Tempo do Evento é posterior ao Tempo de Referência, o que significa que o espaço EVENTO está em uma relação de não concomitância e posterioridade com o espaço FOCO. Esse espaço é elaborado internamente pelo frame de ADOTAR com $m^{8}$ (Maria) como quem adota e $g$, (um gato) como o adotado.

Finalmente, a Figura 11 apresenta o mapeamento de espaços mentais do enunciado:

(9) Ela espera que tudo dê certo.

A sentença (9) cria um espaço do DESEJO E10, que se subordina ao espaço BASE E1. Esse espaço é criado por meio do verbo espera, pois a informação dele indica que se trata 
de um espaço diferente do espaço real, no sentido de se tratar de um hipotético. ${ }^{40}$ No entanto, o verbo está na forma do Presente, motivo pelo qual se subordina ao espaço BASE, e é concomitante a ele. Como esperar está na forma imperfectiva, o espaço E9 se estrutura conforme a categoria tempo-aspectual de IMPERFECTIVO, o que gera um movimento do PONTO DE VISTA do espaço BASE E1 para o espaço do DESEJO E9. A partir do espaço E9 se cria um espaço EVENTO E10 que carrega o conteúdo da esperança da personagem Maria. Esse espaço é elaborado internamente pelo frame de DAR CERTO.

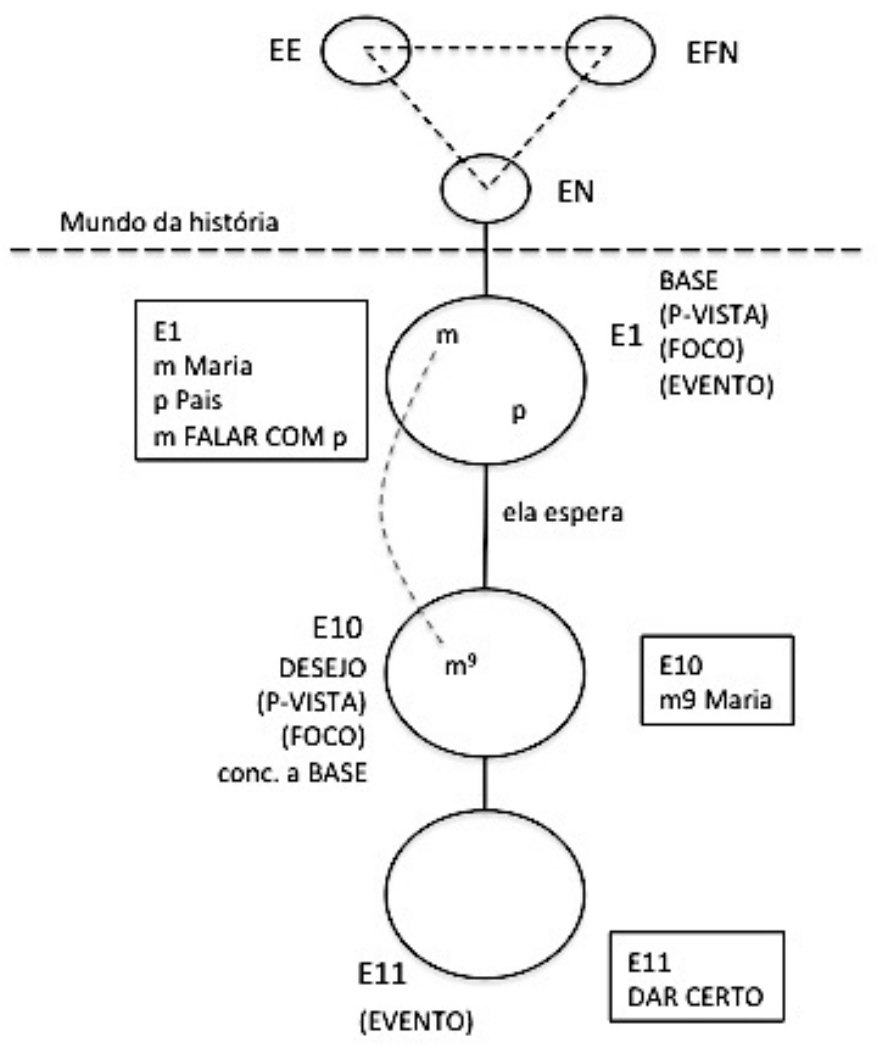

Figura 11 Mapeamento de espaços mentais: sentença (9)

A análise da historinha da Maria vai servir como ponto de partida para a análise das narrativas dos dados de Aldana, que apresento no capítulo 6. Na historinha da Maria, concentrei minha atenção nas relações tempo-aspectuais que o modelo permite descrever. Fiz isso porque o cálculo do PONTO DE VISTA está atrelado a essas relações. No capítulo

\footnotetext{
${ }^{40}$ Lembro que, neste trabalho, estou chamando espaço real o espaço que, dentro da narrativa, se diferencia de espaços de CRENÇA ou espaços HIPOTÉTICOS.
} 
6 vou me concentrar exclusivamente nas relações de PONTO DE VISTA, deixando as relações tempo-aspectuais apenas como pano de fundo. 


\section{Análise}

Este capítulo apresenta a análise das narrativas $A$ viúva e o duende e Índios enterrados seguindo a aplicação do modelo de análise de discurso proposto pela teoria de espaços mentais (FAUCONNIER 1994, 1997; CUTRER 1994; DOIZ-BIENZOBAS 1995; TENUTA 2006; TENUTA E LEPESQUEUR 2014). O item 6.1 apresenta a análise passo a passo da narrativa $A$ viúda e os duendes; já o item 6.2 apresenta a análise da narrativa Índios enterrados. Nas duas análises o foco principal da descrição são os movimentos de PONTO DE VISTA e suas implicações para a construção de significado na narrativa.

\subsection{A viúva e os duendes}

Como toda narrativa, a narrativa $A$ viúva e os duendes é criada a partir da integração de um espaço da enunciação EE com um espaço frame narrativo EFN no nível intersubjetivo da enunciação (MCCLEARY E VIOTTI 2014). A Figura 12 ilustra como se dá essa integração na situação específica de interação de Manuel Erira, o seu conterrâneo e os antropólogos, em 2011, na Reserva Indígana Pastas de Aldana.

Nível intersubjetivo de enunciação

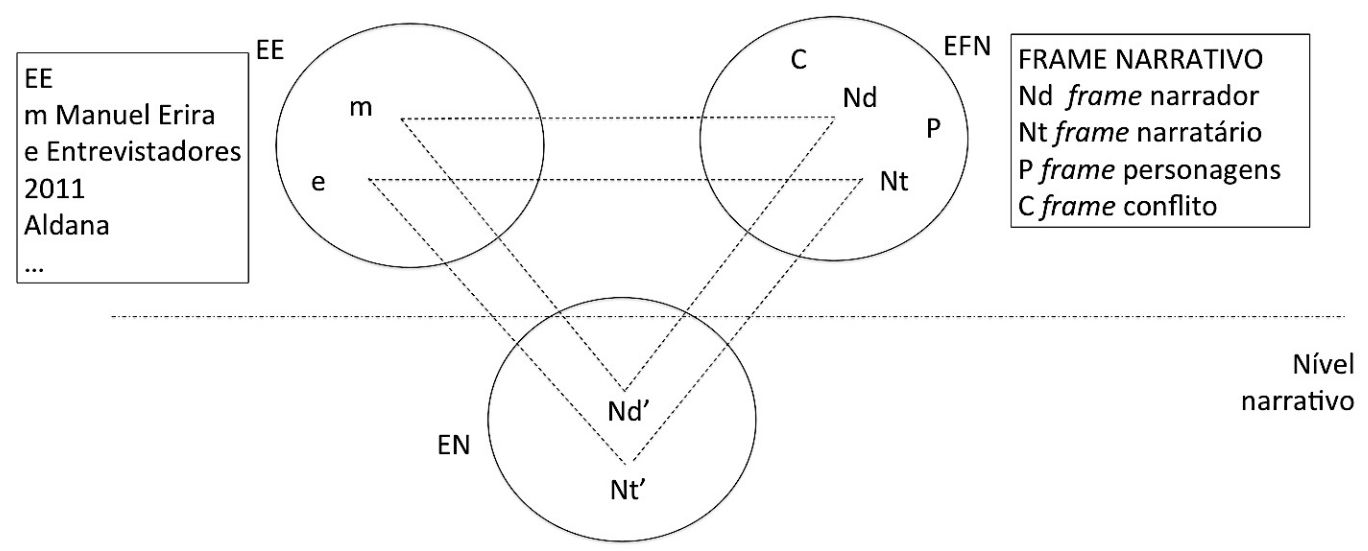

Nível da história

Figura 12 Criação do espaço do narrador EN a partir do espaço da enunciação EE e o espaço frame narrativo EFN 
No espaço da enunciação EE se encontram Manuel Erira e os entrevistadores de carne e osso. Esse espaço também teria informação sobre o local onde se deu a interação, no caso Aldana, o tempo em que aconteceu essa entrevista (2011) e todos os outros conhecimentos compartilhados que eles tinham no momento de fazer a entrevista. Esse espaço EE se integra com o espaço frame de narração EFN, que é elaborado pelo frame da narrativa, o que significa que nele se incluem todas as noções a respeito do que é uma narrativa, ou seja que há narradores, narratários, personagens, conflito etc. O resultado dessa integração é um espaço no narrador EN que tem Manuel Erira como narrador e os entrevistadores como narratários. Esse espaço EN se encontra no Nível narrativo, pois a integração se dá no momento em que Manuel Erira toma a palavra para começar a contar uma história, e essa contação da história se dá num nível que é próprio de uma situação de narração, ou seja, no trânsito do narrar (narrating) para a narrativa (narrative) (GENETTE 1980).

A Figura 13 mostra a análise da estrofe A da narrativa $A$ viúva e o duende, que retomo a seguir para facilitar as referências na análise. Essa estrofe inaugura o nível da história, e nela o narrador descreve o tópico: os mitos.

en cuanto a los mitos pues ant,

anteriormente,

había,

mucha estrategia de nuestros mayores que aparecían espíritu si?

A primeira unidade entoacional (1) cria um espaço BASE, que é ao mesmo tempo FOCO e PONTO DE VISTA, e que é elaborado pela descrição los mitos. Esse espaço é BASE, pois é o espaço no qual começa a narrativa, além de funcionar como âncora dêitica para o cálculo temporal ao longo da narrativa: como visto na Figura 13 é um espaço filho do espaço do narrador EN, e herda dele o tempo presente. EN, por sua vez, herdou, na integração que aconteceu no momento do enunciador se tornar narrador, o tempo do espaço 
da enunciação EE, que é sempre presente. Esse espaço E1 é também FOCO, por ser o espaço que está sendo elaborado no momento do discurso que corresponde à unidade entoacional (1); e é também PONTO DE VISTA, por ser o espaço a partir do qual se conceitualiza o trecho de discurso correspondente à mesma unidade. ${ }^{41}$

A seguir, o abridor de espaço anteriormente cria um espaço E2 cujo tempo é anterior à BASE. Esse espaço passa a ser FOCO, pois é o espaço sendo elaborado no momento do discurso que corresponde às unidades entoacionais 2, 3 e 4. E2 é também EVENTO, pois nele se conceitulaiza a ação do enunciado. Ele é também PONTO DE VISTA, pois é o espaço a partir do qual se elabora esse trecho de discurso. Embora temporalmente o espaço a partir do qual se cria E2 seja E1, o Pretérito Imperfeito das formas do verbo (habia, aparecían) indica que o espaço é elaborado a partir de si mesmo, ou seja, a partir de uma perspectiva interna. Seguindo a proposta de Doiz-Bienzobas, o uso do Pretérito Imperfeito indica a presença de um self experienciador, ou seja que o conceitualizador se desloca para o passado (no caso) e conceitualiza os eventos como vendo-os de uma perspectiva interna. Essa característica é o que diferencia um espaço PERFECTIVO de um IMPERFECTIVO: o primeiro deles não é PONTO DE VISTA e os eventos descritos nele são conceitualizados de fora, já o segundo é PONTO DE VISTA e é conceitualizado de uma perspectiva interna. Esse espaço E2 é elaborado pelos elementos e estratégias, y anciãos, s espíritos e o frame [TER]. ${ }^{42}$

\footnotetext{
${ }^{41}$ Esse espaço, por ser FOCO, é o espaço do Tempo de Referência, entretanto como disse acima, não vou mais explicitar as relações tempo-aspectuais entre os espaços, a não seu quando necessário para o entendimento do mapeamento do PONTO DE VISTA.

${ }^{42} \mathrm{O}$ que chamo de elementos geralmente corresponde a nomes próprios e descrições e aparecerão sempre no texto como aparecem nas figuras seguindo um padrão de $x$ elemento, onde $x$ corresponde às letras que foram designadas para cada descrição ou nome próprio. Os frames serão indicados daqui em diante com colchetes e sempre em letras maiúsculas.
} 


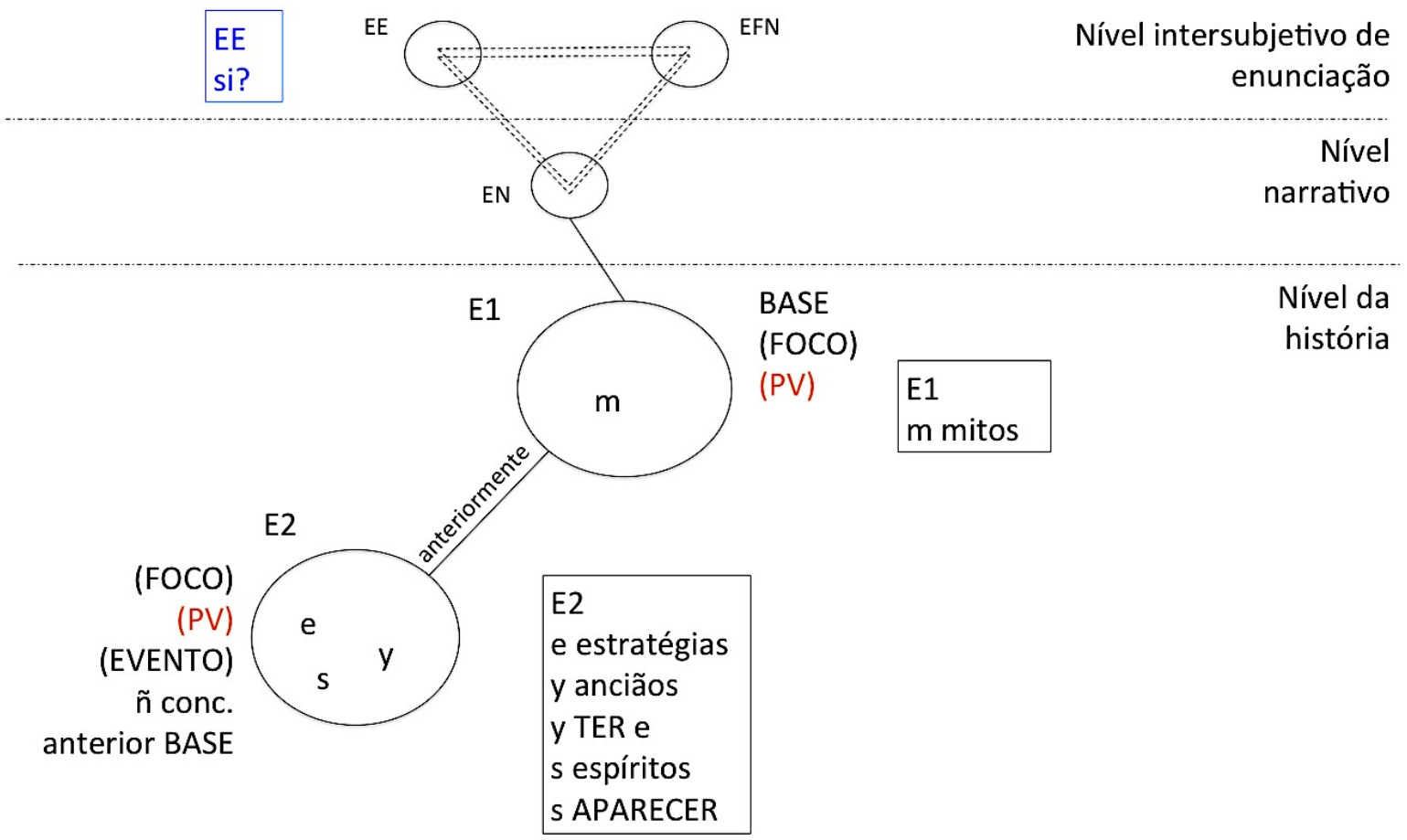

Figura 13 Mapeamento de espaços mentais narrativa $A$ viúva e os duendes: unidades entoacionais 1 a 4 .

Na Figura 13, o primitivo PONTO DE VISTA aparece tanto no espaço E1 como no espaço E2. Isso se deve ao fato de que a imagem em papel é um meio estático, e a construção de sentido no modelo de espaços mentais é dinâmica. Quando se cria o espaço E2, que é IMPERFECTIVO, o PONTO DE VISTA passa do espaço BASE para o espaço E2. Isso é parcialmente resolvido pelos parênteses, que indicam que um espaço foi, em algum momento, FOCO, EVENTO ou PONTO DE VISTA, mas que houve um movimento. Por isso o único espaço que aparece sem parênteses é o espaço BASE, que, no caso dessa narrativa, é sempre o espaço E1.

Um coisa que demostra a permeabilidade dos níveis mencionada acima, é o uso de si?, que fecha a unidade entoacional 4. Essa pergunta não é feita por uma das personagens, ou pelo narrador, mas é uma pergunta feita pelo enunciador aos seus enunciatários para ter certeza de que eles estão acompanhando a narração, ou entendendo do que se trata. Isso mostra como o narrador é sempre também enunciador, e como ele pode entrar e sair do papel de 
narrador assim que a interação precisar. A teoria de espaços mentais, por não se preocupar com a enunciação, não propõe uma maneira de modelar esse tipo de trânsito. Eu escolhi indicar esse trânsito colocando a pergunta si? num frame no espaço da enunciação; no entanto, por questões de tempo e de foco da pesquisa não houve uma indagação a fundo sobre a natureza dessa pergunta, nem de como o trânsito entre níveis se dá. O si? em azul no nível intersubjetivo da enunciação só pretende ressaltar que existe esse trânsito, e quiçá provocar próximas pesquisas.

A narrativa continua:

entonces,

unos conversan que la, 6 la viuda, 7

eso le salía pues a los (com) a los enamorados si?

una persona una muchacha cuando,

iba por ejemplo el joven iba a ver la muchacha,

tonces se le presentaba,

en forma de la novia,

pero lo total no era era (le) un espíritu, 12

que se llama la viuda, 13

eso es en cuanto al (a) (al) al espíritu de los enamorados.

As unidades entoacionais 5 e 6 mostram como o narrador volta a elaborar o espaço E1 BASE, pois utiliza um verbo no presente do indicativo (conversan) o que traz o PONTO DE VISTA e o FOCO também de volta a esse espaço, como se mostra na Figura 14. Os eventos narrados continuam a elaborar o espaço com a descrição unos e o frame [CONVERSAR]. O frame [CONVERSAR] além de elaborar o espaço E1 também cria um novo espaço E3, pois se trata de um verbo de fala, e de uma instância de discurso indireto. E3 é agora FOCO, pois é o espaço sendo elaborado nesse trecho de discurso; é EVENTO, 
pois nele se conceitualiza a ação expressa nos verbos. $\mathrm{O}$ espaço E3 se encontra dentro do domínio da fala. Esse domínio tem uma propriedade interessante: nele existe um PONTO DE VISTA@ que é o do experienciador que falou originalmente. Cutrer (1994, p.324) chama esse PONTO DE VISTA@ de "strong V-POINT" e indica que está associado ao falante reportado: no caso, um falante indeterminado unos que não é o narrador e que eu decidi chamar de personagem, por se tratar de uma narrativa.

Neste momento da narrativa tanto PONTO DE VISTA como PONTO DE VISTA@ estão ativos. PONTO DE VISTA é E1, pois é a partir dele que se cria E3, e PONTO DE VISTA@é E3, pois os eventos descritos nele se conceitualizam a partir de uma perspectiva interna, que seria a do experienciador original cujo discurso está sendo reportado. Isso significa, como mostrado na Figura 14, que a construção do ato de alguém falar se dá do PONTO DE VISTA do narrador no espaço BASE; mas o que é falado, a história de como age a viúva, se faz do PONTO DE VISTA@, interno ao domínio da fala; ou seja, trata-se do ponto de vista dessa personagem genérica descrita como unos (alguns). 


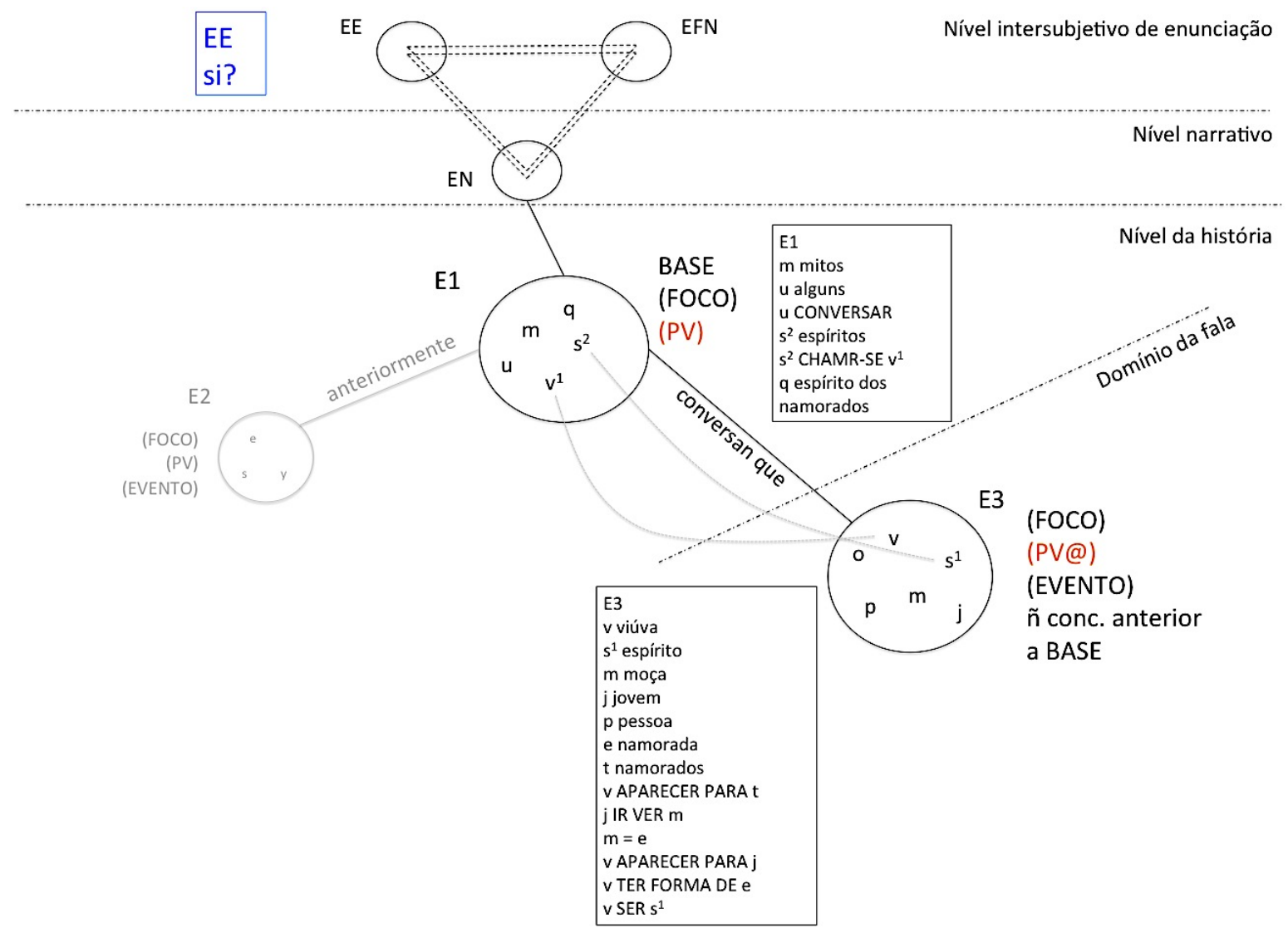

Figura 14 Mapeamento de espaços mentais narrativa A viúva e os duendes: unidades entoacionais 5 a 15.

O verbo sair no Pretérito Imperfeito, na unidade entoacional 8, cria o espaço E3. A unidade entoacional 8 traz de novo a pergunta si? que, como exposto acima, leva a atenção de volta para o Espaço da Enunciação.

O espaço E3 é elaborado pelos elementos: v viúva, $s^{l}$ espírito, $m$ moça, j jovem, p pessoa, $e$ namorada, $t$ namorados, e pelos frames [v APARECER PARA t], [j IR VER m], [m SER e], [v APARECER PARA j], [v TER FORMA DE e], [e v SER s ${ }^{1}$ ]. O elemento $s^{1}$ espírito, no espaço E3, se identifica com o elemento s espírito no espaço E2, o que é indicado pelas linhas curvas pontilhadas. $O$ fato de um elemento em um espaço sendo elaborado, no caso E3, se identificar com um elemento em um espaço que foi elaborado anteriormente na narrativa indica como o modelo de espaços mentais é dinâmico e não linear. Embora o espaço E3 não seja criado a partir do espaço E2, mas a partir do espaço BASE E1, elementos do espaço E2 podem ser retomados no espaço E3 sem ter que satisfazer nenhum 
critério de sequencialidade. Essa possibilidade de identificação também demonstra como os espaços que vão sendo construídos ao longo de um discurso ficam à disposição do falante e do ouvinte e podem ser acessados assim que o discurso e a interação tornarem isso necessário. Os espaços que não estão sendo construídos e elaborados em um momento determinado ficam na periferia, semi-ativos e ainda passíveis de ser acessados ou focalizados; é por isso que nas figuras apresentadas neste capítulo eles aparecem em cinza e de tamanho menor.

Finalmente, os verbos no presente do indicativo nas unidades entoacionais 14 e 15 indicam o retorno do espaço FOCO e PONTO DE VISTA ao espaço BASE E1.

A narrativa continua assim:

II.

en cuanto al duende,

ese es un,

pues según la historia sagrada,

dicen que fue un coro de ángeles que fueron arrojados, del cielo,

pues había como dice una rebelión de,

contra dios.

tonces,

y allá,

los empujó como dice,

que era un como decir un ejército, 28

y iban estaban (diz) que peliando, 
$\mathrm{y}$

contra Dios,

que él quería ser más grande,

O narrador continua construindo a narrativa com a introdução de novas personagens: $o d$ duende, a h história sagrada, e / lenda bíblica (ver Figura 15). Todas essas descrições elaboram o espaço BASE E1. Durante as unidades entoacionais 16 a 19 o espaço BASE E1 é PONTO DE VISTA, pois é o espaço a partir do qual se conceitualiza o trecho de discurso. É também FOCO, pois é o espaço sendo elaborado no momento de narração que corresponde às unidades entoacionais 16 a 19. É também EVENTO, pois é o espaço em que se constrói a estrutura completa do evento ou situação.

Continuando, a unidade entoacional 20 abre um novo domínio de fala com o uso do verbo decir, e cria o espaço E4 que passa a ser FOCO, pois é o espaço que está sendo elaborado no momento que corresponde à unidade entoacional 20. É também EVENTO, pois nele se constrói a estrutura completa do evento. E é PONTO DE VISTA@, ou seja, os eventos nele descritos são conceitualizados a partir da conceitualização de um experienciador que pode ou não ser o narrador. Durante o mesmo trecho de discurso o espaço E1 é PONTO DE VISTA, pois é a partir dele que se constrói E4. 


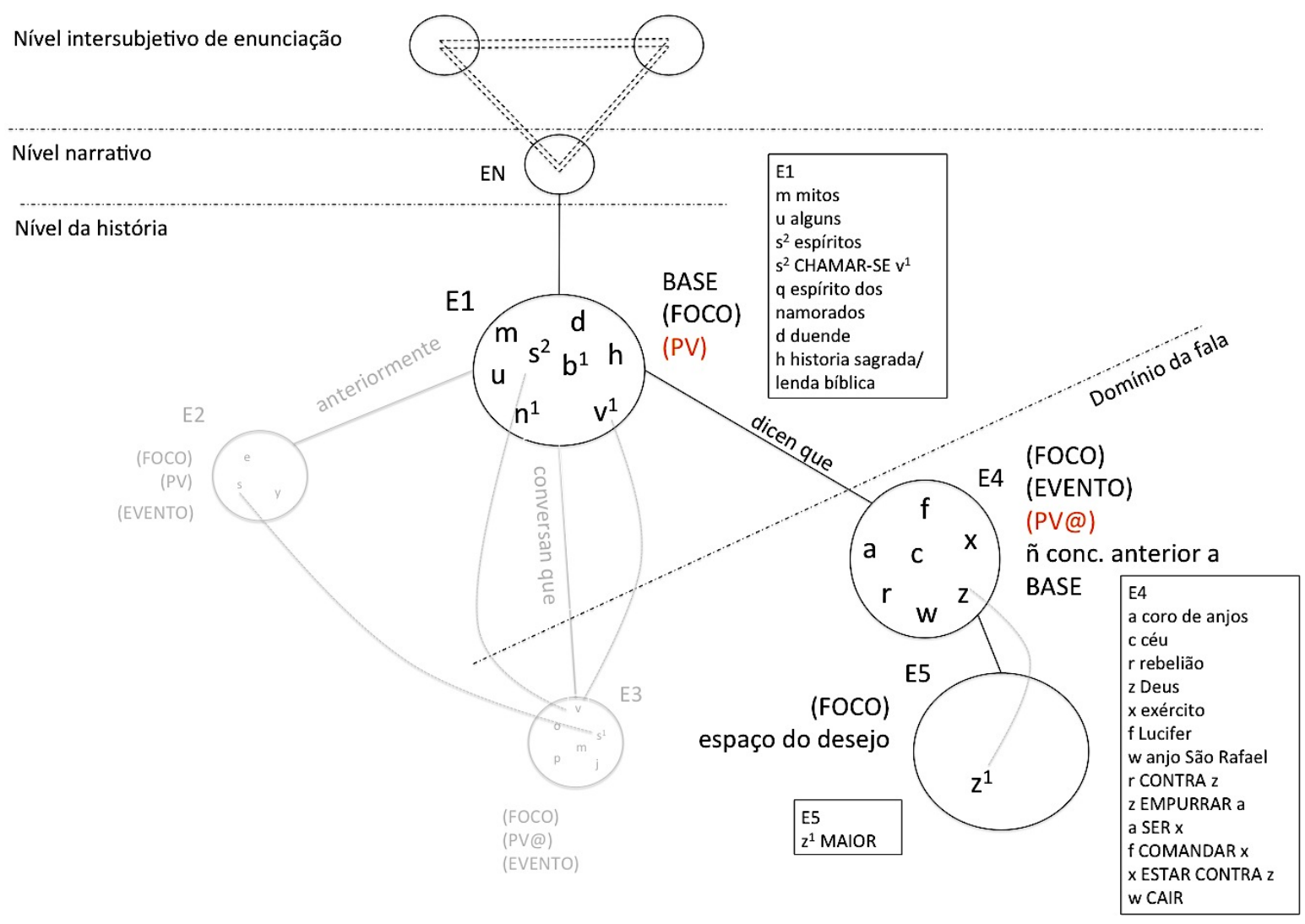

Figura 15 Mapeamento de espaços mentais narrativa A viúva e os duendes: unidades entoacionais 16 a 33 .

Da unidade entoacional 20 à 32, o narrador elabora o espaço E4 com os elementos: a coro de anjos, c céu, $r$ rebelião, $z$ Deus, $x$ exército, $f$ Lúcifer, $w$ Anjo São Rafael, e com os frames [r CONTRA z], [z EMPURRAR a], [a SER x], [f COMANDAR x], [x ESTAR CONTRA z], [e w CAIR].

A unidade entoacional 33 contém um verbo de crença - queria -, que cria um espaço do DESEJO E5, em que $z^{1}$ Deus é maior. O elemento $z^{1}$ Deus, no espaço E5, se identifica com o elemento z Deus no espaço E4 pelo uso de él na unidade entoacional 33. O PONTO DE VISTA@ continua em E4, pois é a partir desse espaço que se cria o espaço da CRENÇA E5. 
A narrativa continua:

entonces como se iba a derrumbar, $\quad 34$

dice pues la historia (de) bíblica, $\quad 35$

que se iba a derrumbar el ángel San Rafael, $\quad 36$

o arcángel Sán Rafael si? $\quad 37$

(G)

$\begin{array}{ll}\text { tonces, } & 38\end{array}$

a fin de que él no se caiga pues Dios dijo detente. 39

As unidades entoacionais 34 a 38 continuam a elaborar o espaço E4. E4 volta a ser FOCO e EVENTO e PONTO DE VISTA@. 


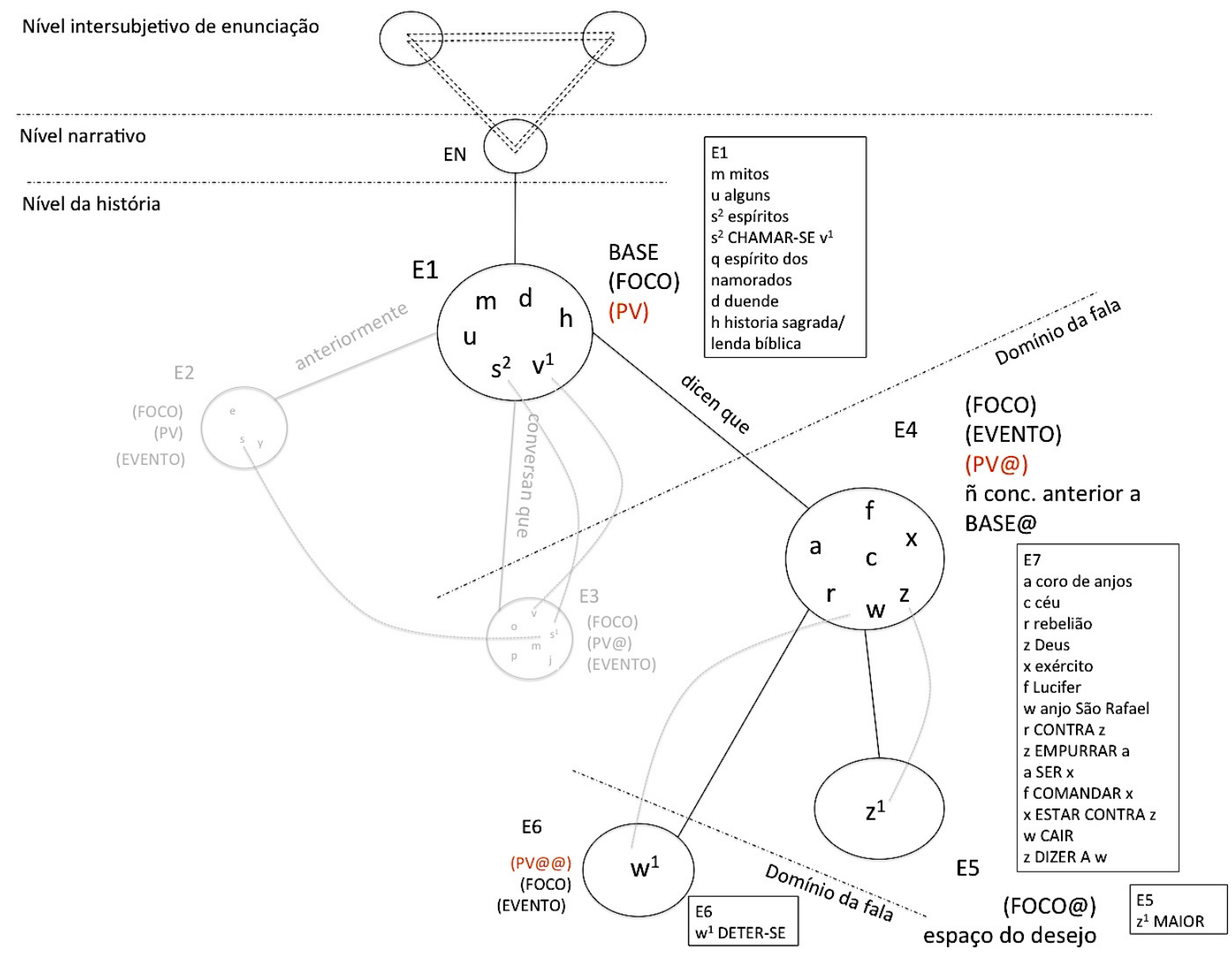

Figura 16 Mapeamento de espaços mentais narrativa A viúva e os duendes: unidades entoacionais 34 a 39.

A unidade entoacional 39 cria um espaço E6 e introduz um novo domínio de fala, desta vez dentro da fala, com o discurso direto Dios dijo: detente, como pode ser visto na Figura 16. Esse espaço E6 passa a ser FOCO, pois é o espaço sendo elaborado nesse trecho de discurso, e EVENTO, pois nele se constrói a estrutura inteira do evento. Ele é também PONTO DE VISTA@@, uma categoria que não foi proposta por Cutrer (1994), sendo, portanto, uma sugestão minha, pelo fato de haver um domínio de fala dentro de outro domínio de fala. Se no caso do domínio de fala há um PONTO DE VISTA@, caracterizado como um "Strong V-POINT" que se refere à conceitualização de quem falou originalmente e cuja fala está sendo reportada, então, no caso de fala dentro da fala, eu suponho que se tenha um PONTO DE VISTA@@, que representa, no caso, a conceitualização de Deus 
falando para o Anjo São Rafael: “detenha-se!”. O espaço E6 é elaborado internamente pelo frame $\left[\mathrm{w}^{1}\right.$ DETER-SE].

Até agora temos que, em duas instâncias diferentes, o narrador fez uso de discurso indireto na narrativa. A Tabela 7 e a Tabela 8 apresentam os trechos das duas instâncias de discurso indireto. Quando comparados, podemos ver que os dois trechos de discurso têm uma diferença formal, que foi indicada com um uma linha que começa alguns espaços mais à direita nas unidades entoacionais $6,20,22,28,30,33,36$. Nessas unidades, há uma ocorrência da conjunção que, típica da estrutura de discurso indireto (Maria disse que o a bicicleta do João é bonita). Comparando as duas instâncias de discurso indireto vemos que, na primeira, só há uma ocorrência da conjunção, enquanto que, na segunda, há seis. No primeiro caso apresentado na Tabela 7, além de haver só uma ocorrência da conjunção, não há nenhuma repetição do verbo de fala que indicaria que aquilo que se narra é o que disseram os anciões ou se se trata de fato de uma informação que o narrador está contando da sua perspectiva. Nesse trecho, trata-se de um caso de discurso indireto livre, em que o narrador toma o ponto de vista da personagem, ou em termos de Genette (1980, p.174), a personagem fala através da voz do narrador e nesse processo os dois se fundem.

entonces,

unos conversan que la,

la viuda,

eso le salía pues a los (com) a los enamorados si?

tonces se le presentaba,

en forma de la novia,

pero lo total no era era (le) un espíritu,

Tabela 7 Primeira instância de discurso indireto na narrativa $A$ viúva e os duendes. Unidades entoacionais 5 a 13. 
Por outro lado, no caso apresentado na Tabela 8, trata-se de discurso indireto, em que a perspectiva é da personagem e o narrador usa recursos linguísticos para indicar que o ponto de vista não é dele. Neste caso o recurso é a atualização do domínio da fala a cada ocasião em que o narrador faz uso da conjunção que. É como se a cada instância de que, o autor estivesse repetindo dicen que.

pues según la historia sagrada,

o la leyenda bíblica,

dicen que fue un coro de ángeles que fueron arrojados,

del cielo,

у que,

pues había como dice una rebelión de,

contra dios.

tonces,

y allá,

los empujó como dice,

que era un como decir un ejército,

y iban estaban (diz)que peliando,

que Lucifer era el que comandaba, $\quad 30$

$\mathrm{y}$,

contra Dios,

que él quería ser más grande,

entonces como se iba a derrumbar, 
a fin de que él no se caiga pues Dios dijo detente.

Tabela 8 Segunda instância de discurso indireto na narrativa A viúva e os duendes. Unidades entoacionais 18 a 39.

Nesta comparação das duas instâncias de discurso indireto também é preciso destacar que a primeira delas faz um uso exclusivo do Pretérito Imperfeito, enquanto, na segunda instância, o uso é dividido entre Pretérito Perfeito e Imperfeito. Como foi exposto no capítulo 5, Cutrer (1994) e Doiz-Bienzobas (1995) propõem que a característica da categoria tempo-aspectual IMPERFECTIVO é a de criar um espaço que é ao mesmo tempo FOCO e PONTO DE VISTA. Doiz-Bienzobas (1995) caracteriza esse movimento de PONTO DE VISTA no espanhol como evocando a consciência da personagem durante a ocorrência do evento no passado. No caso da instância de discurso indireto livre na narrativa $A$ viúva e os duendes, o narrador, ao usar o Pretérito Imperfeito exclusivamente, também está reforçando o significado de que o ponto de vista da personagem é o que comanda e direciona a narrativa, como se estivesse, ele mesmo, se fundindo com a personagem e experienciando os eventos, embora saibamos que não se trata de uma narrativa de experiência pessoal, nem de conhecimento próprio, pois o narrador explicita que eram outros que falavam disso.

Temos então que as duas ocorrências de discurso indireto são de tipos diferentes e que eles criam significados diferentes no que toca ao ponto de vista. No entanto, o modelo de espaços mentais não oferece uma ferramenta para poder lidar com esse tipo de diferenças, pois em ambos os casos temos que o PONTO DE VISTA fica no espaço BASE, na esfera do nível narrativo, e em ambos os casos há um PONTO DE VISTA@ dentro do domínio narrativo, o que dá a entender que as características do ponto de vista nos dois trechos são iguais. ${ }^{43}$ Feita essa diferenciação e a problematização da análise das instâncias de discurso indireto, retomo a análise da narrativa. O último trecho é o seguinte:

\footnotetext{
${ }^{43}$ Um desdobramento da Teoria de Espaços Mentais que poderia lidar com a ocorrência de discurso indireto livre e com a fusão dos pontos de vista do narrador e da personagem é a Teoria de Integração Conceitual (blending) proposta por Fauconnier e Turner (2002). Essa possibilidade não foi explorada na minha dissertação pelas limitações de tempo e porque o foco da minha pesquisa é a Teoria de Espaços Mentais como proposta por Fauconnier (1994, 1997). Pesquisas futuras podem chegar a desenvolver a questão da integração do narrador e da personagem em narrativas.
} 
por eso quedaron unos en el agua otros en el (en el),

los que alcanzaron a llegar al fuego pues se condenaron para siempre.

\section{eh usted ha poseido de pronto,}

\section{le ha salido la viuda o algo o algún comentario aquí en el municipio?}

A partir da unidade entoacional 40, o narrador sai do domínio da fala. O uso do pretérito perfeito nas unidades entoacionais 40 a 43, e 45 indicam a criação de um espaço PERFECTO E7 que é EVENTO mas não FOCO, pois se trata de eventos que aconteceram no passado e cujas consequências se arrastam até o presente, o que significa também que o PONTO DE VISTA é o espaço BASE E1, pois é da perspectiva dele que se conceitualizam esses eventos elaborados em E10, como pode ser visto na Figura 17. O espaço E7 é elaborado internamente pelos elementos: $a^{l}$ coro de anjos, i fogo, $g$ água, $n$ ar, $b$ locais sólidos, e pelos frames [a ${ }^{1}$ CHEGAR EM i], [i CONDENAR-SE], [a ${ }^{1}$ FICAR EM n], e [a ${ }^{1}$ FICAR EM b].

Finalmente, as informações das unidades entoacionais 44 e 46 continuam a elaborar o espaço E1, o que é marcado pelo uso de presente do indicativo nessas unidades. $\mathrm{Na}$ sequência, um dos entrevistadores faz uma nova pergunta para Manuel Erira e isso indica de novo um trânsito para o Nível intersubjetivo da enunciação, em que Manuel Erira deixa de ser narrador, e volta a ser enunciador. 


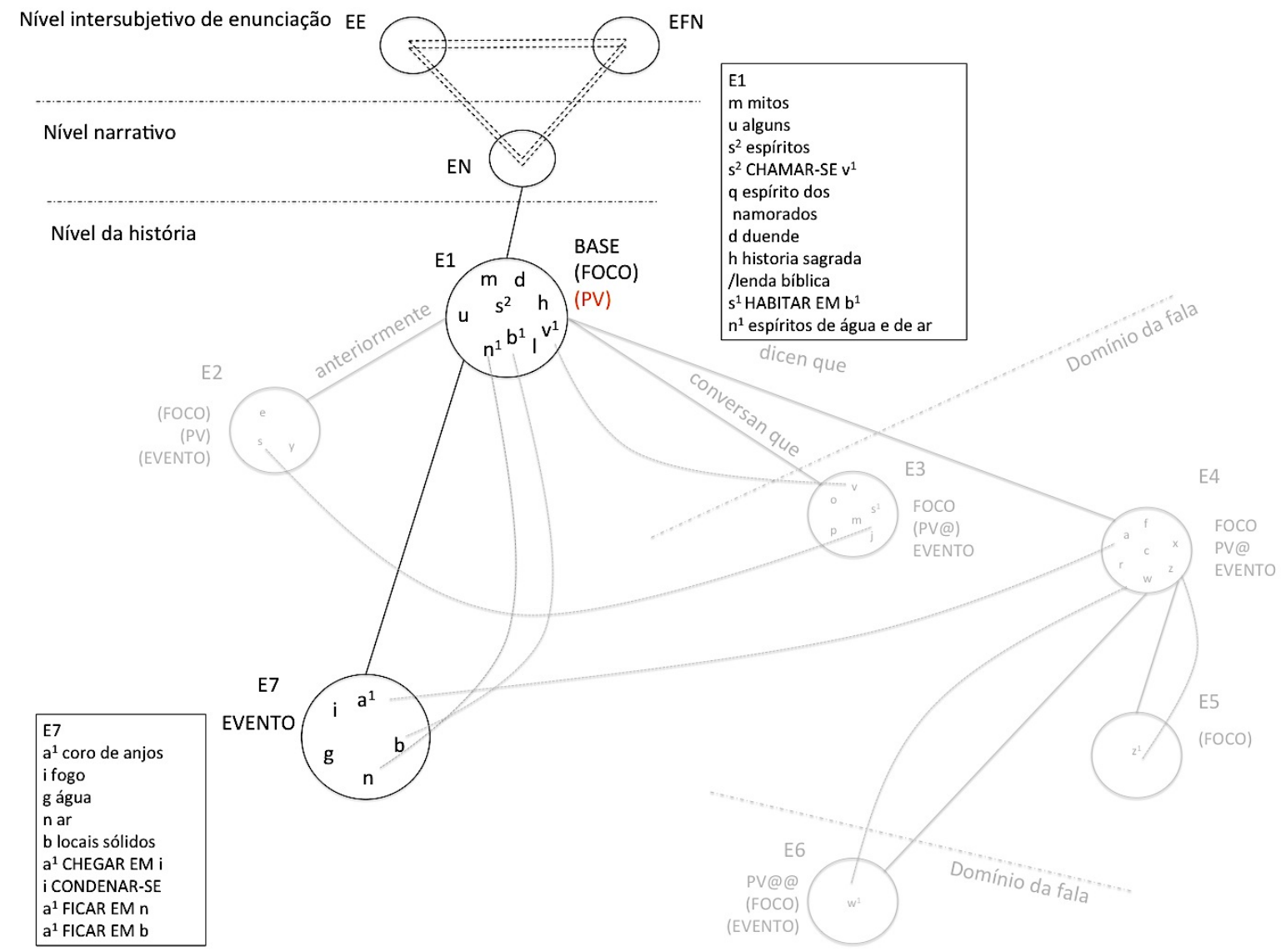

Figura 17 Mapeamento de espaços mentais narrativa $A$ viúva e os duendes: unidades entoacionais 40 a 46.

A Figura 18 a seguir mostra a rede de espaços mentais construída pela narrativa inteira. É importante lembrar mais uma vez que essa rede não é estática; infelizmente, os diagramas são estáticos e planos, mas devemos pensar nessa rede como sendo dinâmica e se modificando a cada enunciado novo. Nas figuras anteriores mostrei como, a cada enunciado, os primitivos discursivos mudam de um espaço para outro, como a criação de cada novo espaço coloca em foco uma parte nova da narrativa, embora os espaços que já foram criados fiquem à disposição na rede de espaços para ser re-elaborados ou para fazer referência a elementos que os estruturam. 


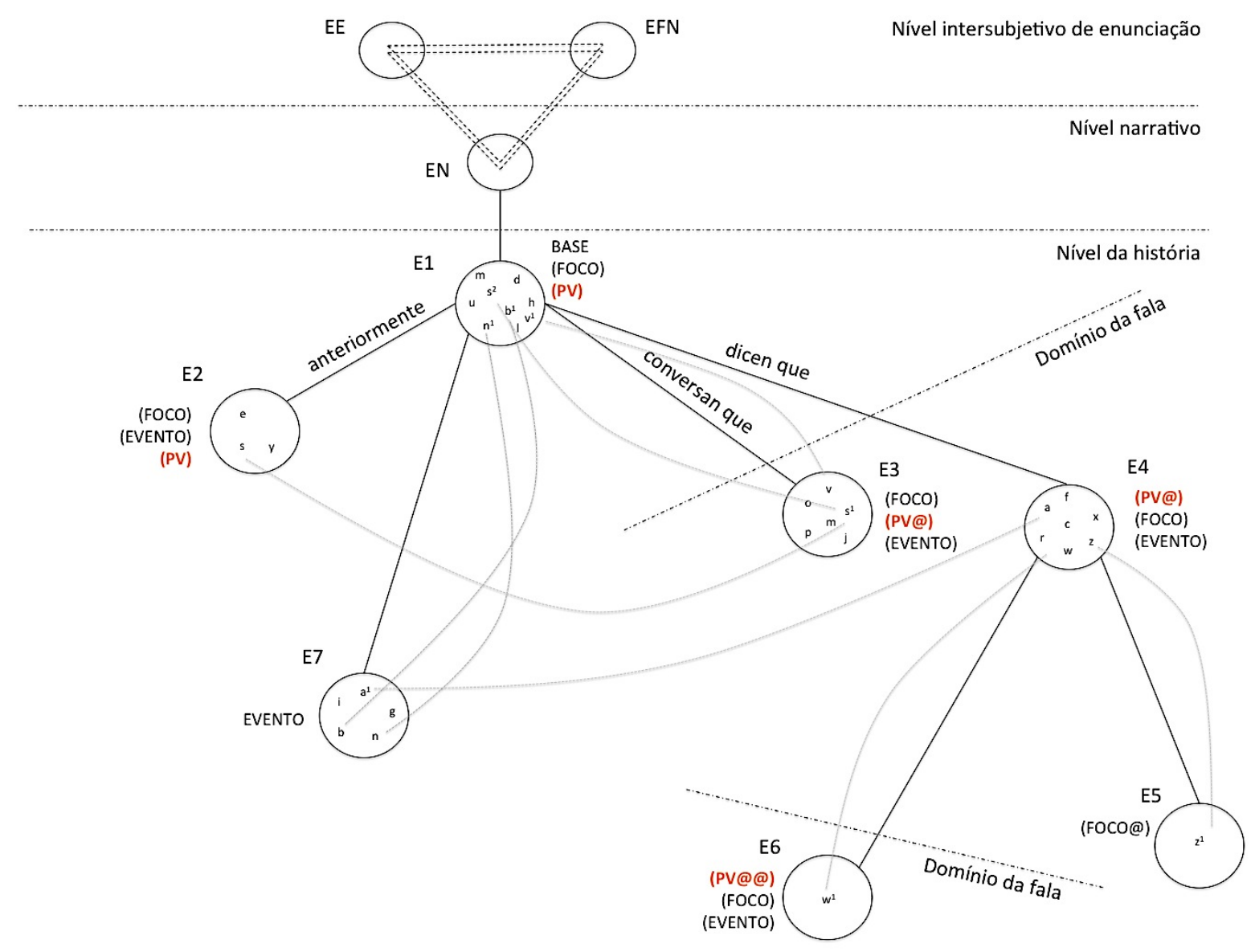

Figura 18 Mapeamento de espaços mentais narrativa $A$ viúva e os duendes.

A seguir, apresento a análise da narrativa Índios enterrados, que permitirá continuar a caracterização do espaço PONTO DE VISTA e do seu comportamento na rede de espaços mentais dentro das narrativas de Aldana.

\section{2. Índios enterrados}

A narrativa Índios enterrados começa, como toda narrativa, pela integração do espaço da enunciação EE com um espaço frame de narração no Nível intersubjetivo da enunciação, como mostra a Figura 12. A integração desses espaços mentais dá como resultado um espaço do narrador EN que faz parte do Nível narrativo. Nesse espaço do narrador EN o falante, que no caso é Manuel Erira, empresta seu corpo para o narrador da história que vai começar a ser contada, e os outros participantes da interação, no caso os entrevistadores, 
passam a ser os narratários nessa situação de narração. A integração dos espaços EE e EFN e a criação do espaço do narrador se dão no momento em que o narrador começa a contar a história, o que também implica um trânsito do narrador para o nível da história onde se descrevem os acontecimentos de que trata a narrativa. A narrativa Índios enterrados começa assim:

I.

nuestros primeros primitivos que habitaron en este mundo terrenal.

\section{cuando ellos se enterraron,}

\section{eh ellos pasaron al mundo de abajo?}

correctísimo.

pues según la prehistoria dan,

que ellos se enterraban,

y se enterraban con todas las rique,

entre todo,

como era si era el cacique él se enterraba con toda la riqueza,

A Figura 19 mostra o mapeamento de espaços mentais que se faz das unidades entoacionais 1 a 7 . Ao começar a narração, o narrador cria um espaço BASE E1 que é também FOCO e PONTO DE VISTA. Esse espaço é presente, pois na integração de espaços ele pegou do espaço do narrador a temporalidade, que este, por sua vez, herdou do espaço da enunciação EE que é sempre e por definição o aqui e agora, ou seja, o presente. ${ }^{44} \mathrm{O}$ espaço E1 é BASE, pois é nele que tem início a narrativa, e porque ele servirá como âncora para os cálculos temporais ao longo da narrativa. Ele é FOCO, pois é ele o espaço sendo elaborado no

\footnotetext{
${ }^{44}$ No começo deste trabalho, mencionei que a assunção de que o espaço BASE é sempre presente pode ser questionada, porque existem narrativas que começam em outros tempos, como, por exemplo, era uma vez um rei... A sugestão que eu posso fazer no momento para resolver essa questão é manter a ideia de que o espaço BASE é sempre presente - até por ter herdado o tempo presente do EN e do EE - e, a partir dele, criar um espaço temporalmente anterior, que vai elaborar o fundo da narrativa.
} 
momento do discurso que corresponde às unidades entoacionais 1 a 3. É também PONTO DE VISTA, pois é a partir dele que vão se criar outros espaços mentais e porque os eventos ou situações nele descritas se conceitualizam a partir dele mesmo. As unidades entoacionais 1 a 3 elaboram internamente esse espaço com os elementos p primitivos e $h$ pré-história. Entre as unidades entoacionais 1 e 2, um dos entrevistadores faz uma pergunta à Manuel Erira, e isso marca um trânsito de volta ao nível intersubjetivo da enunciação. Como exposto no item anterior, o modelo de espaços mentais não propõe um mecanismo para indicar esse trânsito; por isso a informação contida nessas perguntas não está esquematizada em nenhum lugar nos mapeamentos. No entanto, é importante ressaltar que esse trânsito se dá, e que a permeabilidade dos níveis não permite que isso se torne um problema na hora de analisar narrativas que se dão em contextos reais de interação.

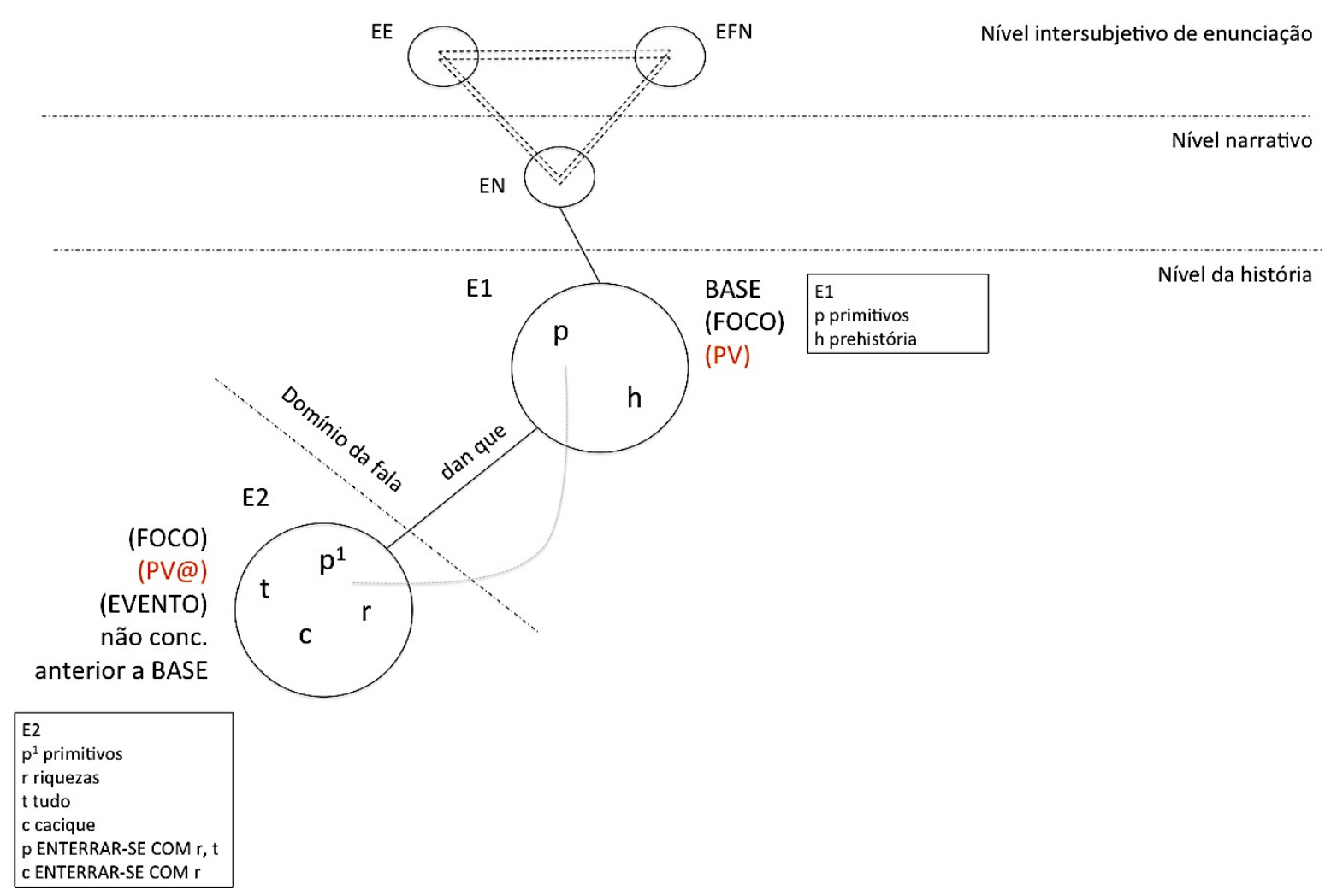

Figura 19 Mapeamento de espaços mentais narrativa Índios enterrados: unidades entoacionais 1 a 7 .

A unidade entoacional 3 abre um domínio da fala com o uso da construção dan que, que, como explicado na nota de rodapé 14 , foi interpretada como equivalente a um verbo de 
fala. Dentro do domínio da fala, o narrador cria um espaço E2 que passa a ser FOCO, pois é o espaço sendo elaborado nesse momento do discurso; e EVENTO, porque nele se constrói o evento ou situação expressa pelo verbo. E2 é caracterizado como PONTO DE VISTA@; como visto na narrativa $A$ viúva e os duendes, PONTODEVISTA@ tem a ver com o ponto de vista do experienciador que, no caso, seria a personagem la prehistoria. O PONTO DE VISTA se mantém em E1, pois é a partir dele que o espaço E2 é criado e que se abre o domínio da fala. O espaço E2 é elaborado internamente pelos elementos: $p^{l}$ primitivos, $r$ riquezas, $t$ tudo, e c cacique, e pelos frames [p ENTERRAR-SE COM $\mathrm{r}$ e t], [c ENTERRAR-SE COM r].

A narrativa continua:

y que le tenían creencia,

de que ellos cuando,

porque en la conquista,

cuando vinieron los españoles,

creyeron que enterrándose se van a salvar no?

y hubo uno que por ejemplo dice la historia,

(que) que quedaba pues por fuera pa que los tape,

Nas unidades entoacionais 8 e 9 o narrador abre um espaço PASSADO E3 a partir do uso do verbo tenían (ver Figura 20). Por conter uma construção que indica uma crença (tenían la creencia de que ellos cuando) se cria também um espaço E4 da crença. Neste ponto, E3 é PONTO DE VISTA, pois além de ser o espaço a partir do qual se cria o espaço E4 da CRENÇA, é também construído por um verbo imperfectivo, o que o torna um espaço IMPERFECTIVO (ver principio de organização discursiva ix)). O espaço da CRENÇA E4 passa a ser FOCO, pois é o espaço sendo elaborado no momento do discurso que corresponde à unidade entoacional 9. Neste ponto, o narrador se interrompe e reformula a narrativa, pelo que o espaço E4 não é elaborado internamente por enquanto. Parece que o 
autor precisa fazer alguma explicação anterior para poder falar da crença que os indígenas tinham.

A narrativa continua com as unidades entoacionais 8 a 14. A unidade entoacional 10 indica a referência temporal do espaço E3 por meio do abridor de espaço mental en la conquista. Até então tínhamos que E3 era um espaço passado, pois tinha sido construído a partir de morfologia temporal de passado, mas na unidade entoacional 10, a referência temporal é revelada. Por ser esse o espaço sendo elaborado, ele é caracterizado como FOCO e EVENTO, pois nele se estruturam os eventos narrados nesse trecho da história. Esse espaço não é PONTO DE VISTA durante as unidades entoacionais 11 e 12, pois nelas o autor faz uso do pretérito perfeito, que expressa as categorias tempo-aspectuais de PASSADO e PERFECTIVO (ver princípios de organização discursiva v) a viii)), que indica que o espaço E3 é FOCO mas não é PONTO DE VISTA. O PONTO DE VISTA se mantêm em E1. O espaço E3 é elaborado internamente pelos elementos $s$ espanhóis, u um (primitivo) e $p^{2}$ primitivos, identificado com o elemento $p^{l}$ no espaço E2, que, como visto na Figura 20, continua disponível para os falantes envolvidos na interação. E3 também é elaborado internamente pelos frames [s VIR], [u FICAR FORA] e [u ENTERRAR p ${ }^{2]}$. A unidade entoacional 12 contem uma pergunta do tipo si? que no caso é no? e também faz parte do nível da enunciação, pois se trata de uma pergunta cuja função é a de ter certeza de que o interlocutor tenha entendido ou esteja acompanhando o discurso. 


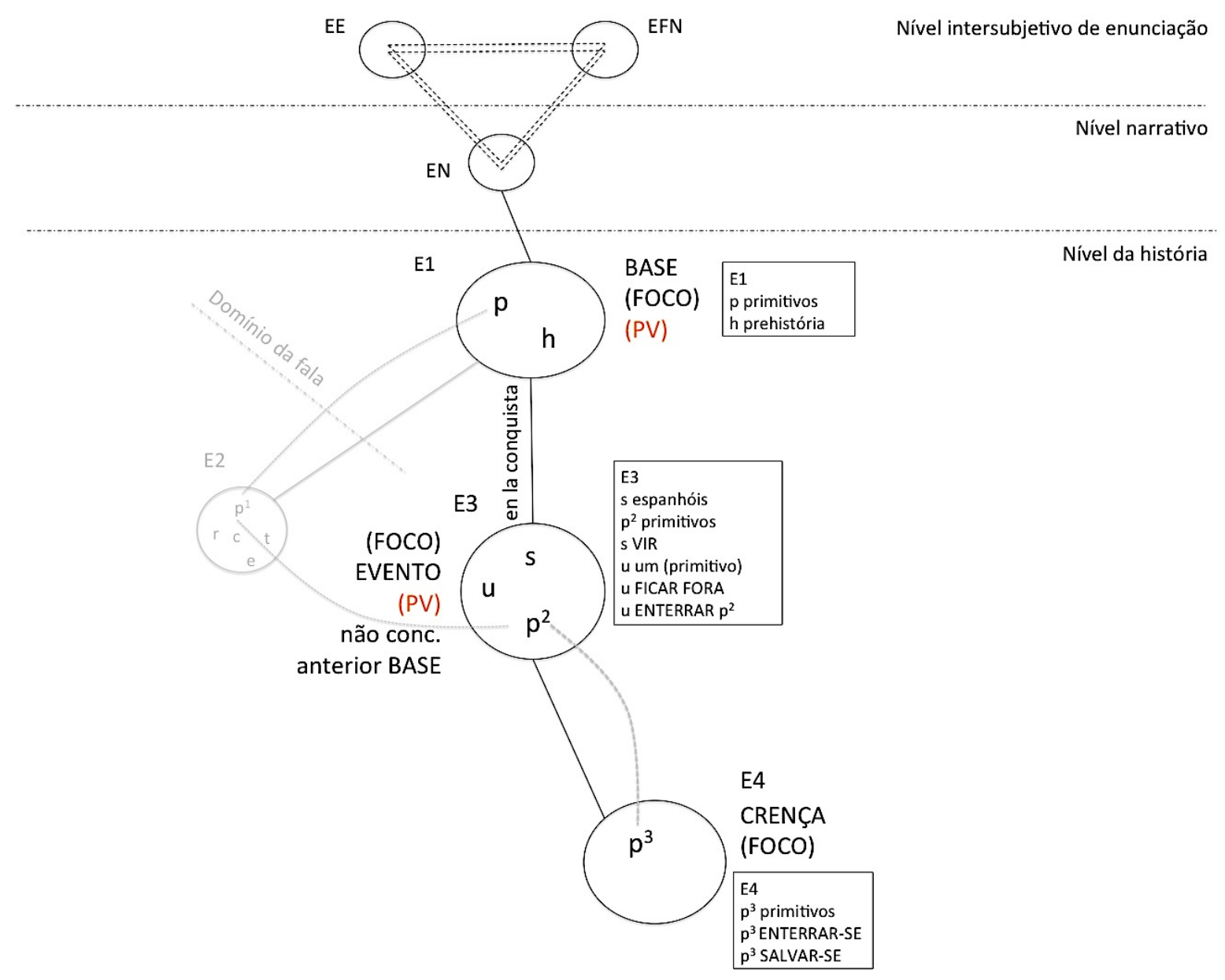

Figura 20 Mapeamentos de espaços mentais narrativa Índios enterrados: unidades entoacionais 8 a 14.

A unidade entoacional 12 cria um espaço da CRENÇA E4 que é FOCO, pois é o espaço que está sendo elaborado. Nesse momento na narrativa, o espaço E3 passa a ser PONTO DE VISTA, pois é a partir dele que se cria o espaço E4 da CRENÇA, e como já foi discutido anteriormente, o primitivo discursivo PONTO DE VISTA responde à pergunta de onde se vê?. No caso, o espaço em que se cria a crença e a partir do qual esta é conceitualizada é o espaço E3. E4 é elaborado internamente pelo elemento $p^{3}$ primitivos, que se identifica com o elemento $p^{2}$ no espaço E3, e pelos frames p3 ENTERRAR-SE e p3 SALVAR-SE. 
A narrativa continua:

pero cuando ellos acordaron, 15

ya no ya pues se ahogaron, 16

ya no hubo aire dentro de donde estaban enterrado,

A Figura 21 mostra o mapeamento das unidades entoacionais 15 a $17 . \mathrm{Na}$ unidade entoacional 15, o uso da conjunção pero indica que o espaço E4 não continua a ser elaborado pois essa conjunção indica uma construção contrafactual, o que significa que a informação sendo elaborada nesse espaço E4 da CRENÇA é contraditória com o que será elaborado no espaço E3, e que é descrito nas unidades entonacionais 15 a 17. Isso quer dizer que, no espaço da crença, os índios iriam sair com vida dos enterramentos, mas que, no espaço E3 do tempo da conquista, eles morreram. O Pretérito Perfeito indica que o espaço a ser elaborado é E3, que é um espaço não concomitante anterior à BASE que, por sua vez, é o espaço pai de E3. Esse espaço E3 continua a ser elaborado a partir dos elementos a ar e $z$ túmulos, e a partir dos frames [p² ACORDAR], [NÃO TER a EM t], e [p $\mathrm{p}^{2}$ ASFIXIAR-SE]. Durante as unidades entoacionais 15 a 17, o espaço E3 volta a ser FOCO pois é o espaço sendo elaborado nesse trecho de discurso, e EVENTO, pois nele se constroem as ações ou situações expressas no verbo. O PONTO DE VISTA volta ao espaço E1, porque é a partir dele que E3 é construído/acessado. Além disso, E3 é um espaço PERFECTIVO, o que indica que FOCO não é PONTO DE VISTA. 


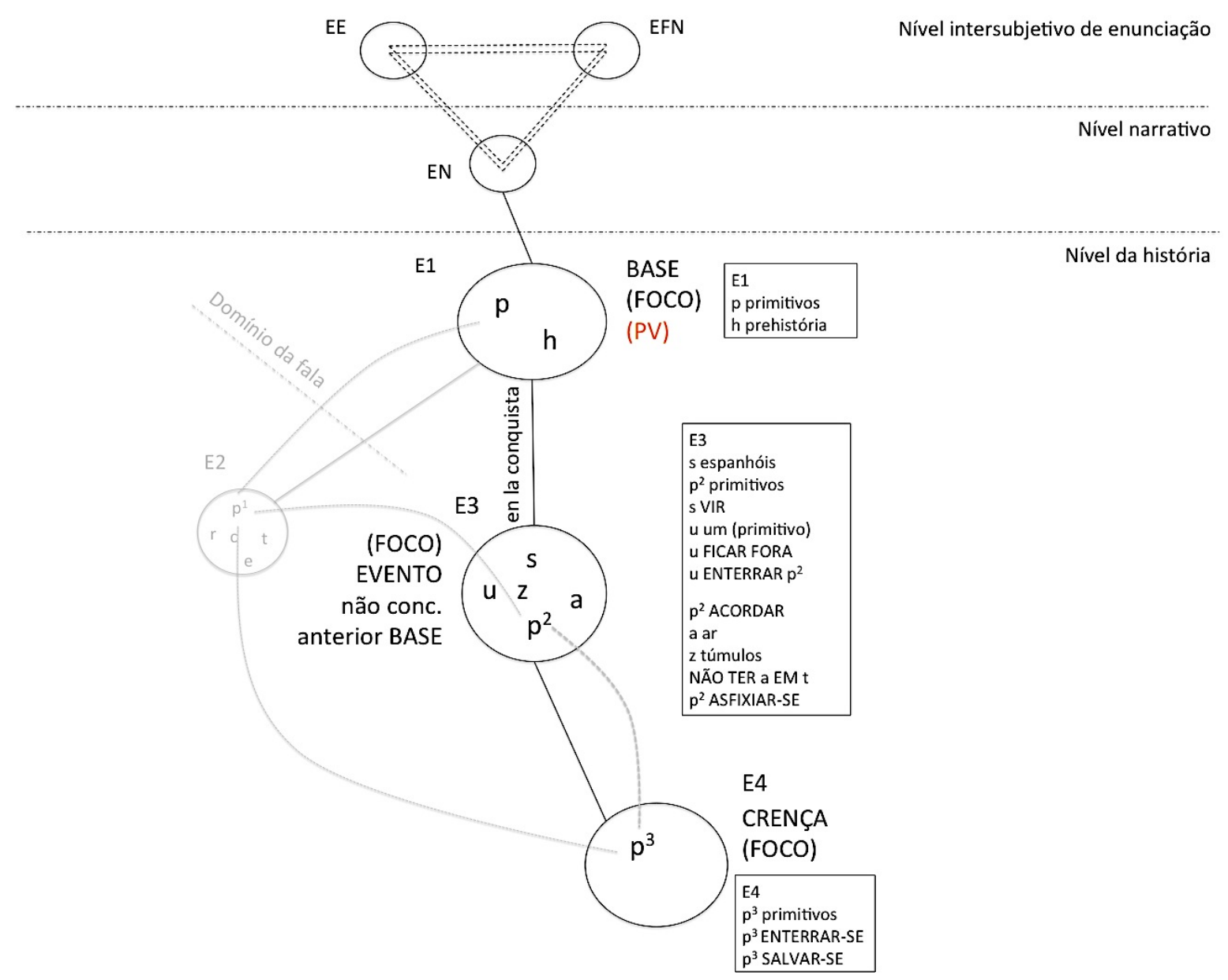

Figura 21 Mapeamento de espaços mentais narrativa Índios enterrados: unidades entoacionais 15 a 17.

A narrativa continua:

II.

$\begin{array}{ll}\text { por eso a ellos se los halla, } & 18\end{array}$

$\begin{array}{ll}\text { con su chicha con su morocho con todo ahí, } & 19\end{array}$

$\begin{array}{ll}\text { eh pues eso si hasta actualmente, } & 20\end{array}$

$\begin{array}{ll}\text { se ha encontrado bases de eso, } & 21\end{array}$

porque acá en la chorrera donde, 22

tengo un lotecito, 23 
As unidades 18 e 19 voltam a elaborar o espaço E1 com os elementos $i$ chicha, $m$ morocho, e com o frame [ACHAR p COM i EM m]. Sabemos que o espaço E1 volta a ser elaborado pelo uso dos verbos no presente. Como exposto acima, o espaço BASE E1 é um espaço PRESENTE que funciona como centro dêitico para construir as relações temporais no discurso. Neste momento na narrativa, o espaço E1 volta a ser FOCO, pois é o espaço sendo elaborado nesse trecho de discurso, e PONTO DE VISTA, pois é a partir dele que se conceitualizam os eventos ou situações do espaço mental.

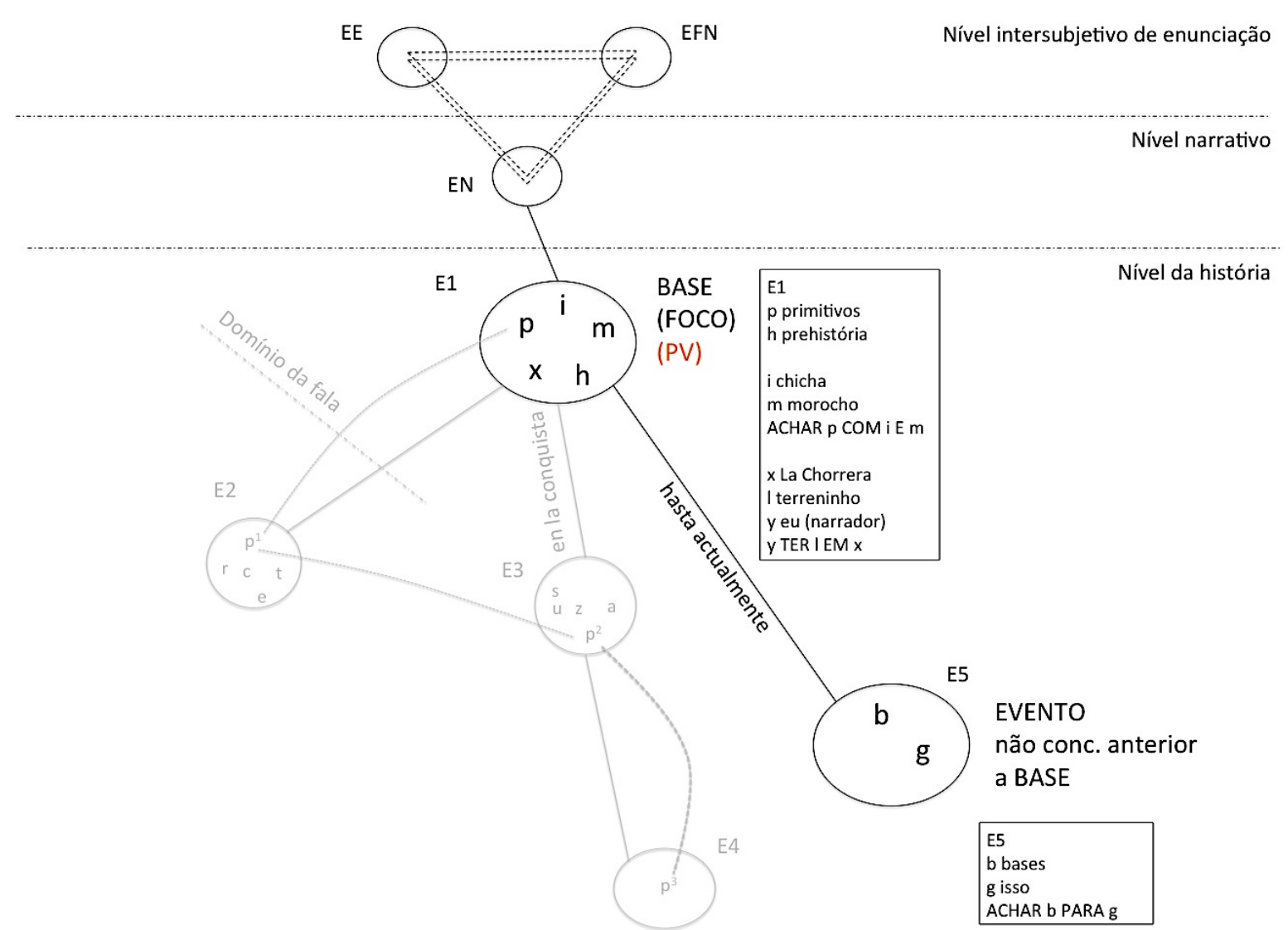

Figura 22 Mapeamento de espaços mentais na narrativa Índios enterrados: unidades entoacionais 18 a 23.

O uso de hasta actualmente e han encontrado nas unidades entoacionais 20 e 21 cria um espaço PERFECTO E5. Como foi exposto na análise da narrativa $A$ viúva e os duendes, a categoria tempo-aspectual PERFECTO indica que o espaço E5 é EVENTO mas não é FOCO nem PONTO DE VISTA, que, no caso, continua sendo o espaço E1. O fato de o 
espaço E5 ser EVENTO mas não ser FOCO cria a significação de que os eventos nele descritos aconteceram no passado mas se arrastam até o presente. Esse espaço E5 é elaborado internamente pelos elementos b bases e $g$ isso, e pelo frame [ACHAR b PARA g].

A narrativa continua:

allí se encontró como dice el cabello ollas todo eso, 24

y no hace mucho que hallaron hasta la olla de chicha. 25

si? 26

tons eso aguanta, 27

eso sí es verdad, 28

pero ellos creían que pues van a salir de nuevo,

no?

en la conquista de los españoles ahí quedaron sepultados.

hasta ahora se los halla pero ya muertos no vivos.

(a)

usted qué cree que va a pasar en el futuro (con el) con el resguardo y con el cabildo?

O uso de verbos no Pretérito Perfeito nas unidades entoacionais 24 e 25, além da referência temporal no hace mucho na unidade entoacional 25, indica a criação de um espaço E6 que é FOCO, pois é o espaço sendo elaborado nesse trecho da narrativa, e EVENTO, pois os eventos ou situações descritas no verbo são nele elaborados (ver Figura 23). O PONTO DE VISTA se mantém em E1, pois é a partir dele que se cria o espaço E6, e é um espaço PERFECTIVO. A unidade entoacional 26 é outra instância de $s i$ ?, que foi caracterizada acima como um trânsito entre os níveis narrativo e intersubjetivo da enunciação. 


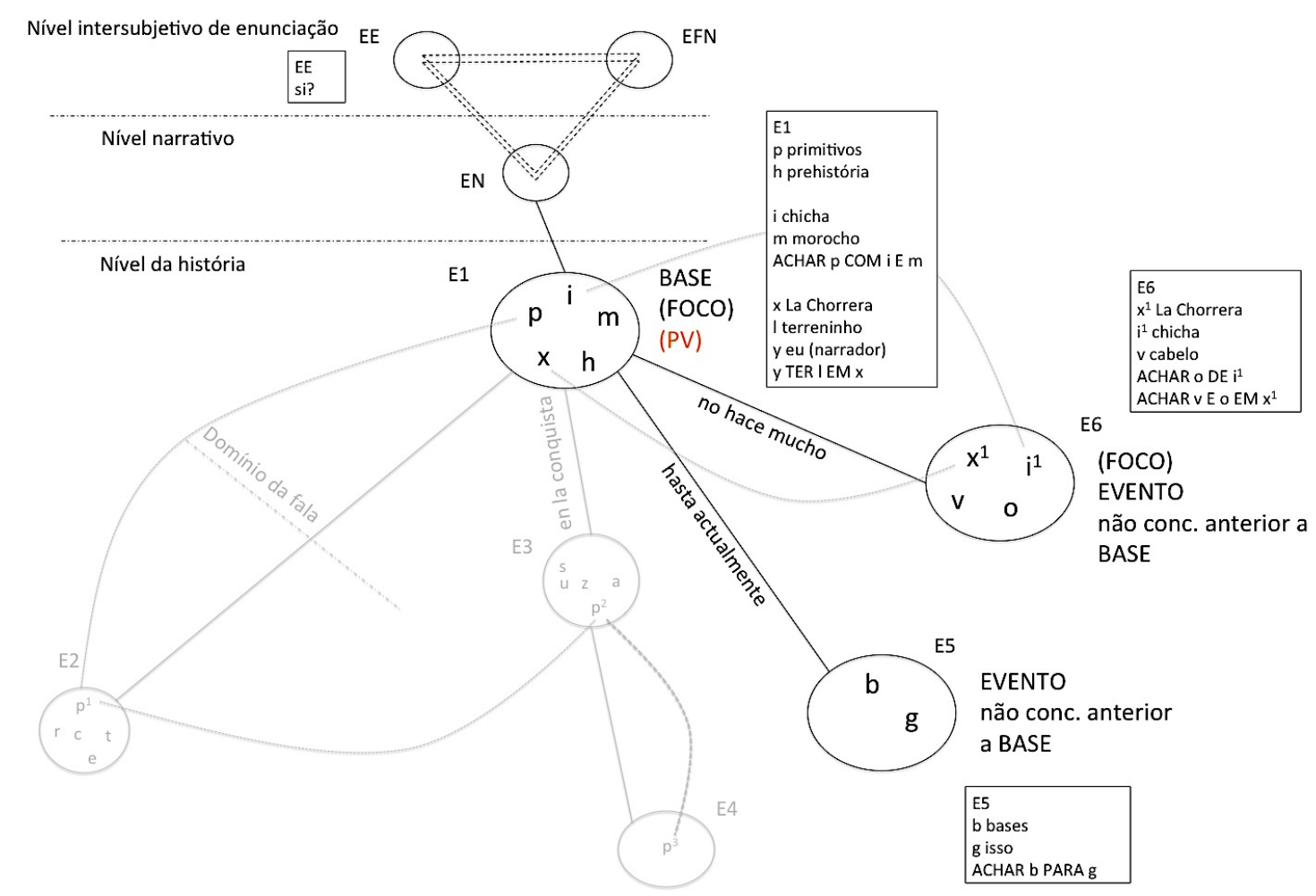

Figura 23 Mapeamento de espaços mentais narrativa Índios enterrados: unidades entoacionais 24 a 32 .

Nas unidades entoacionais 27 e 28, Manuel Eria faz uma avaliação da veracidade dos fatos que ele narrou anteriormente. Eu considero que essa avaliação faça parte do Nível intersubjetivo da enunciação, pois se trata de uma avaliação da história que ele acabou de contar; caso isso seja acertado, o conteúdo dessas suas unidades entoacionais poderia chegar a elaborar o espaço da enunciação EE. Finalmente, nas unidades entoacionais 29 a 32, o narrador faz um resumo dos acontecimentos narrados. Em 29 ele volta a elaborar o espaço da CRENÇA E4; nessa reelaboração o espaço E4 volta a ser FOCO pois é o espaço sendo elaborado naquele trecho de discurso, e PONTO DE VISTA fica na BASE, pois é a partir dele que se acessa a informação do espaço da CRENÇA E4. A unidade entoacional 30 consiste na pregunta no? que também faz parte do nível da enunciação, como descrito para a unidade entoacional 12 acima. Com a unidade entoacional 31, o narrador volta a atenção para o espaço E3, e com isso E3 volta a ser FOCO e EVENTO. Finalmente, o autor volta ao espaço E1, que, no caso, é BASE, FOCO, PONTO DE VISTA e EVENTO.

A Figura 24 mostra o mapeamento da narrativa Índios enterrados na sua totalidade. 


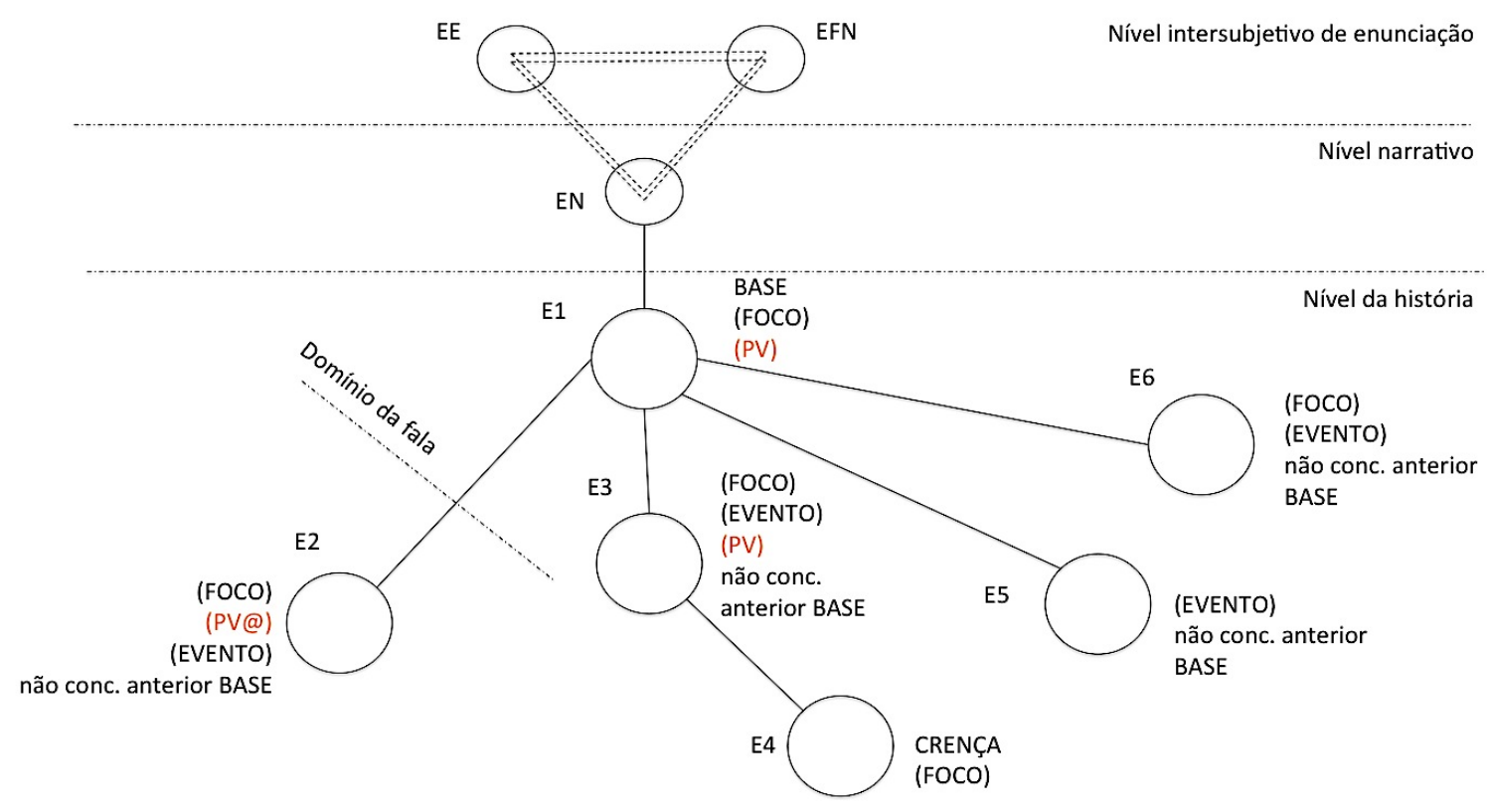

Figura 24 Mapeamento de espaços mentais narrativa Índios enterrados. 


\section{Considerações finais}

Esta dissertação pode ser dividida em duas grandes partes. A primeira dela pode ser chamada de contextualização, e a segunda de análise. Na primeira parte, descrevi o Município de Aldana, onde foram coletadas as narrativas que analisei na minha pesquisa de mestrado. Descrevi a localização da Reserva Indígena Pasto de Pastás em Aldana, no Departamento de Nariño ao sul da Colômbia, perto da fronteira com o Equador. Descrevi os modos de vida dos seus habitantes e suas práticas de criação de gado e cui e de plantação de hortaliças. Descrevi, além disso, as condições em que essas narrativas emergiram: uma entrevista etnográfica feita por três estudantes de antropologia da Universidade Nacional da Colômbia com Manuel Erira, que é uma pessoa cujo conhecimento sobre os assuntos dos pastos é reconhecido na comunidade. Essa descrição foi importante para a pesquisa, pois a contextualização de onde e em que condições foram contadas essas histórias ajuda a uma melhor compreensão de seu conteúdo e de sua emergência.

$\mathrm{Na}$ primeira parte também descrevi as condições ecológicas (MUFWENE 2008) da emergência da variedade de espanhol falada em Aldana. O século XVI, no qual os conquistadores espanhóis pisaram pela primeira vez no território em que se localiza a atual Aldana, foi marcado por um forte multilinguismo: na área coexistiam as línguas pastás, abad, quillacinga e quéchua, e a elas se somou o espanhol, que, então, já tinha tido contato com outras línguas na América do Sul e, antes ainda, na própria Península Ibérica e nos navios durante as viagens que trouxeram a conquista à América. Desde antes da chegada dos espanhóis até hoje a zona se caracteriza também por um permanente intercâmbio econômico, especialmente com o sul. Talvez - e fica para ser pesquisado em profundidade por mim ou por outras pessoas interessadas no espanhol andino colombiano - a variedade de língua falada pelos pastos esteja relacionada com a variedade de espanhol falada ao norte do Equador, e o processo de perda das línguas nativas tenha se dado pelo efeito da preponderância do espanhol em terras equatorianas, inclusive pela força, num primeiro momento, do quéchua na área. Como foi descrito na seção 1.1., os dois primeiros séculos 
do território do atual Departamento de Nariño contavam com uma proporção bastante maior de indígenas do que de espanhóis, embora a população de índios tivesse diminuído rapidamente no primeiro século. Se essas proporções demográficas se mantiveram por dois séculos, é difícil compreender por que e como o espanhol terminou por expulsar a língua pastás, que segundo os teóricos (HERNÁNDEZ DE ALBA 1946; ORTIZ 1946; RODRÍGUEZ ROSALES 2001), se extinguiu no século XVIII. É possível que a chave para a compreensão desse fenômeno se encontre nas práticas comerciais que a população de Aldana mantêm até hoje com a fronteira sul.

No capítulo 2 apresentei a definição de narrativa de Genette (1980), que afirma que uma narrativa é o discurso oral ou escrito que conta uma série de eventos reais ou ficcionais. Também discuti a propostas de Bruner $(2002 ; 2004)$ de que a construção das narrativas é dependente de convenções culturais e do uso da linguagem, e a possibilidade de que a análise das narrativas de Aldana fosse algo similar a uma janela que me permitisse conhecer as noções culturais relevantes para os indígenas pastos como um grupo.

A segunda parte começa com o capítulo 3 em que apliquei o modelo da etnopoética de Hymes (1997), o que me ajudou a estabelecer uma primeira organização das narrativas $A$ viúva e os duendes e Índios enterrados. Essa estrutura, que emergiu da observação da relação da forma com o conteúdo das narrativas, permitiu minha aproximação de forma geral ao significado desses discursos, e a maneira com que eles foram construídos tanto formal como conceitualmente. Além disso, a estrutura obtida dessa primeira análise foi de grande utilidade nos capítulos de análise, em primeiro lugar porque a observação cuidadosa das relações de forma e conteúdo me permitiram ver diferenças em trechos que pareciam similares - por exemplo as duas instâncias de discurso indireto na narrativa $A$ viúva e os duendes, em que a presença e ausência da conjunção que me permitiu reconhecer uma diferença de estilo que provavelmente indique também uma diferença de focalização na narrativa; em segundo lugar, porque a estrutura de episódios, estrofes e unidades entoacionais foi de muita utilidade na hora de fazer referência a trechos de narrativas nas análises do capítulo 6 . 
Finalmente, apliquei o modelo de espaços mentais à descrição e análise de duas narrativas inteiras produzidas em espanhol de Aldana, o que me permite fazer as seguintes afirmações:

1. O modelo descreve com muito detalhe e de maneira bastante evidente - pelo uso dos mapeamentos gráficos - como se estruturam as narrativas em termos de relações temporais no discurso e sequencialidade das ações narradas. Essa estrutura permite ver as relações que se estabelecem entre os elementos significativos da estruturação da ação, além de compreender menções anafóricas a elementos já presentes na narrativa, e como, cognitivamente, tanto o falante, como o ouvinte conseguem acompanhar narrativas complexas, como as analisadas para essa dissertação. Além disso, o modelo ilustra como os interlocutores conseguem acompanhar e organizar discursos dentro do discurso, como é o caso da introdução de discursos indiretos e diretos nas duas narrativas. Por último, o modelo também permite entender como o falantes e seus interlocutores estabelecem e reconhecem relações de elementos com o espaço BASE. Uma vez incluída e compatibilizada com o modelo de espaços mentais, a proposta de McCleary e Viotti (2014) da criação do espaço do narrador e da inclusão do espaço da enunciação na análise de narrativas, o modelo permitiu também explorar como o falante e seus interlocutores estabelecem relações dos eventos narrados com o aqui e agora da enunciação.

2. O modelo também permite descrever como se dá o deslocamento temporal que acontece no discurso, e ilustra como cognitivamente conceitualizamos relações temporais e aspectuais complexas. Tal é o caso dos espaços PERFECTO, PERFECTIVO e IMPERFECTIVO. Em espanhol, as formas do Pretérito Perfeito são utilizadas tanto para indicar espaços mentais PERFECTOS como PERFECTIVOS, como foi visto na análise nos casos do espaço E7 na Figura 17, e do espaço E3 na Figura 20. Ambos os espaços são espaços PASSADOS, mas se diferenciam pelo fato de que o espaço PERFECTO E7 é EVENTO mas não FOCO, e o espaço PERFECTIVO E3 é EVENTO e FOCO. Essa diferença explica por que o uso de Pretérito Perfeito nas unidades entoacionais 40 a 43, e 45 tem uma leitura 
de um evento que acontece no passado mas tem consequências no presente: o evento é de fato construído em um espaço PASSADO, mas o FOCO é um espaço presente, no caso E1 BASE, à luz do qual os eventos do espaço E7 PASSADO são interpretados.

A diferença aspectual entre espaços PERFECTIVOS e IMPERFECTIVOS também foi descrita utilizando o modelo de espaços mentais. Embora em espanhol as formas de Pretérito Perfeito e Pretérito Imperfeito sejam diferentes, os dois tempos verbais compartilham o fato de serem passado, mas apresentam uma diferença aspectual. $\mathrm{O}$ modelo de espaços mentais descreve essa diferença de maneira simples, pois ela se resume ao comportamento de um dos primitivos discursivos, no caso, o PONTO DE VISTA. A diferença é ilustrada na análise com a comparação dos espaços E2 na Figura 13 e E3 na Figura 20. Os dois espaços são espaços PASSADOS, mas o espaço E2 é um espaço IMPERFECTIVO, o que indica que ele é EVENTO, FOCO e PONTO DE VISTA. Já o espaço E3 é um espaço PERFECTIVO, o que indica que ele é EVENTO e FOCO, mas não PONTO DE VISTA, que no caso é o espaço E1 na Figura $20{ }^{45}$

3. A distinção entre espaços PERFECTIVOS e IMPERFECTIVOS como proposta por Cutrer (1994) me permitiu problematizar o funcionamento do primitivos discursivo PONTO DE VISTA no modelo de espaços mentais. A definição dada para esse primitivo discursivo em Fauconnier $(1994,1997)$ é que PONTO DE VISTA é o espaço a partir do qual outros espaços são criados/acessados. No entanto, no desenvolvimento que Cutrer (1994) faz do modelo, em que a autora lida com categorias temporais, o PONTO DE VISTA é colocado como sendo interno nos espaços IMPERFECTIVOS. Essa nova possibilidade amplia a definição proposta por Fauconnier $(1994,1997)$, no sentido de que existiria agora a possibilidade de

\footnotetext{
${ }^{45}$ Esse espaço é PERFECTIVO durante as unidades entoacionais 10 a 13 da narrativa Índios enterrados. Na Figura 20 ele aparece descrito como (PONTO DE VISTA), e no caso os parênteses indicam que ele em algum momento é também PONTO DE VISTA. Esse momento não é aquele que corresponde às unidades entoacionais 10 a 13, durante as quais o espaço E1 é PONTO DE VISTA.
} 
haver espaços que são criados/acessados a partir de si mesmos. Doiz-Bienzobas (1995) leva adiante a proposta de Cutrer (1994) para a distinção de espaços IMPERFECTIVOS e PERFECTIVOS, e afirma que a diferença entre Pretérito Perfeito e Pretérito Imperfeito em espanhol é que o segundo é conceitualizado a partir de um PONTO DE VISTA interno que evoca a presença do que ela chama um self-experienciador que vê os eventos de dentro, diferentemente de um self-narrador que vê os eventos de fora, e que corresponde a construções que fazem uso do Pretérito Perfeito.

Parece-me então - e uma pesquisa mais longa e aprofundada se faz necessáriaque o primitivo discursivo PONTO DE VISTA é uma categoria híbrida que indica a partir de qual espaço um outro espaço é elaborado/acessado, o que ajuda a descrever a estrutura maior das narrativas da que tratei no item (a); mas também é uma categoria que permite descrever a partir de onde se constroem e interpretam os eventos descritos em um espaço específico. É essa característica do espaço PONTO DE VISTA que eu descrevi como o de onde se vê? no capítulo 5, como uma tentativa de explicar, em termos visuais, o funcionamento da categoria, e que pretendia estabelecer um diálogo com o conceito de focalização de Genette (1980), o que me leva à próxima observação.

4. Após a minha análise das narrativas de Aldana, posso concluir que a categoria de PONTO DE VISTA da teoria de espaços mentais e o conceito de focalização proposto por Genette (1980) não são equiparáveis. Doiz-Bienzobas (1995) propõe que no espaço IMPERFECTIVO onde FOCO e PONTO DE VISTA são o mesmo espaço exista a interpretação de um self-experienciador que vê os eventos de uma perspectiva interna, e que os espaços PERFECTIVOS, pelo espaço FOCO não ser PONTO DE VISTA, sejam interpretados como tendo uma conceitualização de um self-narrador que vê os eventos de fora. A proposta da autora, parece-me, poderia começar a construção de uma ponte entre a proposta do modelo de espaços mentais e a proposta de focalização de Genette (1980). No entanto, a categoria de PONTO DE VISTA não chega a ser suficiente para descrever os jogos de focalização e voz 
propostos pelo autor. Pesquisas mais aprofundadas se fazem necessárias para poder ampliar as possibilidades do primitivo discursivo PONTO DE VISTA e para discutir melhor a relação que os self-experienciador e self-narrador propostos por Doiz-Bienzobas (1995) podem chegar a ter com as noções de narrador e personagem propostas na narratologia. A presença de narrador e personagens também é discutida no item (e) a seguir.

5. A possibilidade de haver um PONTO DE VISTA e um PONTO DE VISTA@ na narrativa nas instâncias de discurso direto e indireto permite estabelecer alguma noção de diferentes pontos de vista na narrativa, como os do narrador e os das personagens. No entanto, essa possiblidade não é explorada nem por Cutrer (1994), que é quem propõe a existência de PONTO DE VISTA@, nem por Doiz-Bienzobas (1995), que é quem fala do efeito de haver um self-experienciador que tem uma perspectiva interna dos eventos. O ponto de vista de personagens e o ponto de vista do narrador também não é explorado por Fauconnier (1994, 1997), que embora fale em algumas ocasiões que o PONTO DE VISTA indica a perspectiva de personagens, como foi explicado com o exemplo de Aquiles e a tartaruga, não faz uma descrição maior de como seria o funcionamento do primitivo discursivo se esse marcasse sempre perspectiva no sentido da focalização do Genette (1980).

Embora a distinção entre PONTO DE VISTA e PONTO DE VISTA@ seja interessante e inclua o ponto de vista do experienciador original do que está sendo elaborado no domínio da fala, temos o problema de não poder diferenciar uma instância de discurso indireto e uma de discurso indireto livre. A principal diferença entre estes dois tipos de fala reportada é o jogo que se dá entre voz e focalização, onde no discurso indireto livre a perspectiva da personagem se funde com a voz do narrador (GENETTE 1980). Talvez seja interessante propor alguma categoria de voz no modelo de espaços mentais que permita descrever a riqueza desses jogos narrativos. 
Por último, gostaria de fazer uma observação que não surge diretamente da análise das narrativas feita a partir da aplicação do modelo de espaços mentais, mas que emergiu da observação detalhada das narrativas durante um período de dois anos, e que sempre chamou a minha atenção. Trata-se de que, na narrativa $A$ viúva e os duendes, o falante usa o discurso indireto livre quando narrando uma história que faz parte do conhecimento tradicional da comunidade. Isso pode significar que ele tenha uma facilidade maior para reconhecer o conhecimento dos outros como próprio nesses casos, diferentemente da instância de uso do discurso indireto, em que o narrador conta fatos de que ele tem conhecimento a partir da história bíblica. Embora essa seja uma diferença notável falta uma pesquisa etnográfica que trate a fundo a relação desses indígenas com as fontes de conhecimento (tradicional vs literárias ou religiosas) para se poder afirmar com certeza que essa é a motivação para o uso de uma ou outra forma de discurso indireto. 


\section{Referências}

ARANGO VILLALÓN, V. (2012). Caminaré al vaivén del tiempo: Reflexiones sobre el tiempo en Aldana. Trabajo monográfico, Universidad Nacional de Colombia.

ARBOLEDA TORO, R. (2000). El español andino. Forma y Función vol.13. Bogotá: Universidad Nacional de Colombia, pp.85-100.

ARBOLEDA TORO, R. (2002). El español andino, segunda parte. Forma y Función vol.15. Bogotá: Universidad Nacional de Colombia, pp.15-40.

BOYD-BOWMAN, P. (1976). Patterns of hispanich immigration to the Indies until 1600. The Hispanic American Historical Review, vol.56 no.4. Duke University Press, pp. 580-604.

BRANDT, L. \& BRANDT, P. A. (2005). Making sense of a blend: A cognitive--semiotic approach to metaphor. Annual Review of Cognitive linguistics, v. 3, n. 1, p. 216249.

BRUNER, J. (2002). Fabricando histórias: Direito, Literatura, Vida. São Paulo: Letra e Voz.

BRUNER, J. (2004). Life as Narrative. Em: Social Research Vol.71 No.3. Pp: 691-710.

CALERO, L.F. (1997). Chiefdoms under siege, Spain's rule and native adaptation in the Southern Colombian Andes, 1535-1700. Albuquerque: University of New Mexico Press.

CERRÓN PALOMINO, R. (1987). Linguística Quechua. Cuzco: Centro de Estudios Rurales Andinos.

CHAFE, W. (1994). Doscourse, Consciousness and Time. Chicago \& London: The University of Chicago Press.

CLARK, H. (1996). Using language. Nova Iorque: Cambridge University Press.

CUTRER, M. (1994). Time and Tense in Narrative and in Everyday Language. Tese (Douturado em Ciências Cognitivas e Linguística) - Universidade de California, San Diego. 
DOIZ-BIENZOBAS, A. (1995) The Preterit and the Imperfect in Spanish: Past Situations vs. Past Viewpoint. Tese (Doutorado em Linguística)- Universidade de California, San Diego.

FAUCONNIER, G. (1994). Mental Spaces: aspects of meaning construction in language. Cambridge: Cambridge University Press.

FAUCONNIER, G. \& TURNER, M. (2002). The way we think: Conceptual blending and the mind's hidden complexities. Nova Iorque: Basic Books.

FAUCONNIER, G. (1997). Mappings on Thought and Language. Cambridge: Cambridge University Press.

FILLMORE, C. J. (2003). Double-decker Definitions: the Role of Frames in Meaning Explanations. Em, Sign Language Vol. 3 No. 3, pp.263-295. Academic Research Library.

FIORÍN, J. L. (2005). Capítulo 3: Do tempo. Em: As astúcias da enunciação. São Paulo: Editora Ática.

GENETTE, G. (1980). Narrative Discourse: An essay in method. Nova Iorque: Cornell Univeristy Press.

HERNANDÉZ DE ALBA, G. (1946). The highland tribes of Southern Colombia. Em STEWARD J. H. (ed.) Handbook of South American Indians, vol.2. Washington: Government Printing Office.

HOPPER, P. J. \& THOMPSON S. A. (1980). Transitivity in Grammar and Discourse. Em: Language Vol.56 No.2, pp. 251-299. Linguistic Society of America.

HYMES, D. (1994). Ethnopoetics, oral formulaic theory and editing of texts. Em: Oral Tradition, N.9 V.2. pp. 330-370.

KLAPPROTH, D. M. (2004). Narrative and Social Practive: Anglo-Western and Australian Aboriginal Oral Tradition. Berlin: GmbH \& Co.

LAKOFF, G. (1987). Idealized Cognitive Models. Em: Women, Fire and Dangerous Things. Chicago: The University of Chicago Press.

LANGACKER, R.W. (2008). Cognitive Grammar: a basic Introduction. Nova Iorque: Oxford University Press.

LABOV, W. \& WALETZKY, J. (1967). Narrative Analysis: Oral versions of personal experience. Em: Essays on the verbal and visual Arts, June Helm (ed.). Seattle: 
Washington Press.

LIDDELL, Scott K. Grammar, gesture, and meaning in American Sign Language.

Cambridge/New York: Cambridge University Press, 2003.

MCCLEARY, L. \& VIOTTI, E. (2014). Espaços integrados e corpos partidos: vozes e perspectivas narrativas em línguas sinalizadas. Em: SCRIPTA V.18, N.34, pp. 121139. Belo Horizonte: PUC Minas.

MUFWENE, S. S. (2008). Language evolution, Contact, competition and change. London: Continuum.

NARVÁEZ RAMÍREZ, G. A. (2007). Elementos para la historia económica del Departamento de Nariño (II). Em: Tendencias, Vol. VIII No. 2, pp.95-128. Universidad de Nariño.

NARVÁEZ RAMÍREZ, G. A. (2006). Elementos para la historia económica del Departamento de Nariño. Em: Tendencias, Vol. VII No. 2, pp.7-28. Universidad de Nariño.

OAKLEY, T. (2009) From attention to meaning: explorations in semiotics, linguistics, and rhetoric. New York, Oxford, Brussels: Peter Lang.

ORTIZ, S.E. (1946). The native tribes and languages of Southwestern Colombia. Em STEWARD J. H. (ed.) Handbook of South American Indians, vol.2. Washington: Government Printing Office.

REICHENBACH, H. (1974). Elements of symbolic logic. Nova Iorque: Free Press.

RESGUARDO INDÍGENA DE PASTAS ALDANA (2006-2007). Plan de vida Resguardo de Pastás, Desarrollo con identidad. Disponível em: www.aldananarino.gov.co/apc-aa-files/.../PLAN_DE_VIDA.doc

RICOEUR, P. (1988). L'identité narrative. Conferência proferida na Faculdade de Teologia da Universidade de Neuchatel para obtenção do Título de Doctor Honoris Causa.

RODRÍGUEZ ROSALES, H.E. (2001). Las lenguas pasto y quillasinga en el Departamento de Nariño. Revista Hechos y Proyecciones del Lenguaje, no.11. Pasto: Universidad de Nariño, pp.1-14

ROSCH, E. Principles of categorization. Cognition and categorization, pp.27-48. Hillsdale, NJ: Lawrence Erlbaum. 
TENUTA, A. (2006). Estrutura narrativa e espaços mentais. Belo Horizonte: UFMG.

TENUTA, A. \& LEPESQUEUR, M. (2014). The Mental Spaces Model and an analysis of non-canonical past verbal values. Em: Selected papers from the 4th UK Cognitive Linguistics Conference, pp. 284-304.

ZIMMERMAN, K. (1995). Lenguas en contacto en hispanoamérica, nuevos enfoques. Madrid: Iberoamericana. 


\section{Anexo}

en cuanto a los mitos pues ant, anteriormente,

había, mucha estrategia de nuestros mayores que aparecían espíritu si?

entonces, unos conversan que la, la viuda, eso le salía pues a los (com) a los enamorados, si? una persona una muchacha cuando, iba por ejemplo el joven iba a ver la muchacha, tonces se le presentaba, en forma de la novia, pero lo total no era era (le) un espíritu, que se llama la viuda, eso es en cuanto al (a) (al) al espíritu de los enamorados. en cuanto al duende, ese es un, pues según la historia sagrada, o la leyenda bíblica, dicen que fue un coro de ángeles que fueron arrojados, del cielo, y que, pues había como dice una rebelión de, contra dios. tonces, y allá, los empujó como dice, que era un como decir un ejército, y iban estaban (diz)que peliando, que Lucifer era el que comandaba,

$\mathrm{y}$, contra Dios, que él quería ser más grande, entonces como se iba a derrumbar, dice pues la historia (de) bíblica, que se iba a derrumbar el ángel San Rafael, o arcángel Sán Rafael si?

tonces,

a fin de que él no se caiga pues Dios dijo detente.

por eso quedaron unos en el agua otros en el (en el), en el fue(go),

los que alcanzaron a llegar al fuego pues se condenaron para siempre. los que quedaron en el aire son, los espíritus que se encuentra en el aire en el agua en cualquier parte, y quedaron en las partes más como digo sólidas o, 
o donde ellos pueden habitar,

eh si en casualmente personalmente lo viví en carne propia,

era con la vieja.

ésta ésta espíritus,

ese sale como le diría yo,

(en) en la menguante.

casi todo espíritu es propicio (en) en las lunas llenas no?

(por eso ahí es donde ellos,)

y habitan en los lugares como digo silenciosos o (a),

o que haiga unos montes.

en el agua bueno.

total yo,

para haber sufrido con este espíritu como dice cuerpo a cuerpo fue cuidando papas.

y allí llegó,

allí me privó.

la forma de ella es (la),

tiene unos senos grandes que los cruza así y se los echa al hombro.

la falda es colorada,

pañolón sombrereta de paja,

eso es todo,

pata pelada.

sobre el duende bueno yo ver no lo he visto al espíritu,

solamente a un hijo le pegó el duende entonces,

el duende se encuentra de tantas clases,

hay el duende travieso,

el duende sucio,

el duende trabajador,

el llorón bueno de todo,

hay esos espíritus.

tonces el duende trabajador lo pone a la persona a quien le haya cogido eso a trabajar,

a hacer en (lo que) lo que lo mande.

porque la persona que está (en ese) en ese estilo de que está enduendado,

él lo ve le manda hace,

pero cuando al momento de hacer las cosas no halla nada,

si?

todo se le hace una ilusión.

si es el duende sucio,

ese le (ah) por ejemplo (a la )más en los hogares,

les bota suciedades en la comida,

hay el travieso,

ese le corta a usted la ropa el cabello bueno hace locuras.

tonces,

esa es la contesta (para) para ustedes,

que vayan entendiendo,

que eso es lo que (se) se puede saber.

yo ver no lo he visto porque sería un mentiroso pa(ra) decir lo ví.

ese era el duende trabajador. 
él trabajaba cogía las herramientas y vamos a trabajar, y lo levantaba, pero eso sí pues hay cura.

la curación del es sahumarlos, santiguarlos, con un juete (de de de), de cerda, sacarlo (y) y listo.

con eso ya queda la persona, libre del espíritu.

ya se ha ido todo como dice el encanto, no señor yo no.

en cuanto a la relación del tiempo ha cambiado en su totalidad. anteriormente creíamos como dice en las cabañuelas, que había las dos estaciones, ahora ya no las hay. anteriormente nuestros mayores, porque de ellos aprendimos nosotros, tenían un momento de siembra.

y el tiempo de la cosecha, eso no era todo el tiempo que estaba sembrando ni cosechando, eso era,

(pa) el tiempo había que había seis meses de verano y seis meses de inviernos, si?

tonces, ahorita ya no se conoce que cabañuelas, porque ya está dando,

llueve, hace verano, hela, tonces eso ya ha cambiado en su totalidad el tiempo.

si?

eso sería en cuanto a la previsión del tiempo.

la parte más solida es donde, donde, habitan (las), como le diría en las chorreras, eh son las partes sólidas, o en los bosques, o en las casas abandonadas, que no vive na(die), donde los espíritus apropean ese espacio para poder vivir. pero ellos no son espíritus como le diría malos, (no), todo espíritu, tiene su función, son espíritus cuidadores, si?

eso no es que le va(yan), 
claro.

eso no le digo? todo en toda parte existe,

lo menos por ejemplo el chutún,

ese es un espíritu que cuida,

el chutún se aparece (en) en un animal,

sería eh ejemplo,

sería un conejo,

sería una serpiente si?

esas son las diferentes,

y él habita más donde hay frutos.

los chimbalos,

el pepino,

ya?

tonces él habita allí,

y al que no le gusta pues eso sí lo engranoja,

ese es un espíritu que cuida, en una chagra,

hacerle ronchas en el cuerpo,si?

para eso pues tiene que ocupar,

las plantas que curan (eh eh eh) esas,

(eso eso) esas rasquiñas.

esas son (un) unas personas que viven en este mundo.

y se utilizan,

en un derecho propio de que son compadres,

$\mathrm{y}$,

se como le diría,

se encuentran como enamorados,

después de ser enamorados,

se

se inquietan del uno al otro a hacer el sexo.

ya?

entonces eso es lo que viene a ser los cagones.

$\mathrm{y}$,

por qué no tienen como le digo una,

creencia ellos un respeto sagrado,

porque usted después de que es compadre,

es por la santa iglesia,

en cuando pues la religión es impuesta no?

eso si hay que creerlo pero de todas maneras,

eh eso cometen un error,

y esos no tienen salvación.

y por qué se ha comprobado eso?

cuando conversaban nuestros mayores,

que,

para,

saber que si es esa pareja son los compadres los han perseguido,

tienen que echarle perrero,

o una peinillazo en el centro, 
pero del lomo,

para separarlos,

tonces allí usted sabe,

(si) si son los cagones,

tonces allí dicen,

por vos comadre por vos compadre.

se separan y se han salvado.

pero el que hace esos,

esos secretos tiene que ser bien esperto en las cosas.

porque si no los corta los mata y se condenan.

porque ellos (es)tan en vida andando,

cuanto mueren ya se van,

ya no hay nada ni rastros dellos ya?

y son un par como,

como animalitos como marranos chillan,

eso,

si señor,

eso van pasando y (onde) onde cometieron el acto sexual,

ahí llegan,

de ahí comienzan y salen.

por onde haigan andado.

hay tres mundos,

el mundo de arruba es la,

es el astro,

o sea la corte celestial donde está la cosmología,

están las estrellas el sol bueno y qué sé yo más arriba planetas,

es el mundo de arriba,

el mundo del medio es el que habtamos nosotros,

si?

es lo que accimos nuestro accionar,

en nuestro diario vivir.

y el mundo de abajo es lo que la fuerza viva,

de lo que están los espíritus y todo lo que está en la hermana naturaleza.

esos son los tres mundos,

correctamente.

esas son las influencias astrales,

porque nuestros mayores,

ellos (de) desde ellos no estudiaron,

si?

nuestros viajos antiguos,

y ellos eran pues sabios astrólogos de todo sentido,

ellos por eso podían descubrir el mundo de arriba,

que es lo que va a suceder.

ellos tenían su como dice su visión,

en pues propiamente donde podian ellos (es)tar viendo,

las estrellas el sol todo el cosmos de la naturaleza.

bueno según a prehistoria, 
yo estuve leyendo una prehistoria donde rra esto,

dice que anteriormente,

el hombre provino del mono,

si?

y que tenían unos bancos hecho el hueco para introducir la cola por medio de ese hueco.

el hombre es proveniente del mono segunda la prehistoria,

pero no lo puedo decir yo,

porque pues,

yo no he estudiando sino por leyenda si?

esa es (la) la razón.

pues no se sabe porque según hoy,

dan tantas tantas versiones,

de que el mundo hubo que la humanidad hubo,

no sabemos.

por eso espero de ustedes que descubran y me traigan,

a avisar que cómo es esto,

ya?

los infieles fueron unos habitantes primitivos,

los primeros que habitaron aquí,

si?

ellos,

ellos (te) (cre) tenían todo como (como no) (como eh) (lo) lo de ahora,

ellos eran alfareros,

ellos unos se dedicaban a la agricultura,

otros se dedicaban a las artesanías si?

ellos no eran tan,

y tenían más saber y poder que los de ahora,

para ellos no solamente era el estudio,

lo que acabé de mencionarles anteriormente.

ellos estudiaban es así mismo les dirigía (la) la hermana naturaleza,

los astros,

si?

ellos se dirigían por eso,

bueno,

son pues personas normal como nosotros.

correctame,

claro de allí viene la descendencia,

si?

ese por eso es (los) los indígenas,

que hubieron diferentes razas pues ustedes mismo lo saben,

que hubieron diferentes razas,

de indios,

unos eran más tenían más recurso económicos,

otros eran más pobres

y así.

vivieron ellos,

y de allí viene el desprenderse, 
(la) (la) la ideología de indios,

ya?

nuestros primeros primitivos que habitaron en este mundo terrenal.

correctísimo.

pues según la prehistoria dan,

que ellos se enterraban,

y se enterraban con todas las rique,

entre todo,

como era si era el cacique él se enterraba con toda la riqueza,

y que le tenían creencia,

de que ellos cuando,

porque en la conquista,

cuando vinieron los españoles,

creyeron que enterrándose se van a salvar no?

y hubo uno que por ejemplo dice la historia,

(que) que quedaba pues por fuera pa que los tape,

pero cuando ellos acordaron,

ya no ya pues se ahogaron,

ya no hubo aire dentro de donde estaban enterrado,

por eso a ellos se los halla,

con su chicha con su morocho con todo ahí,

eh pues eso si hasta actualmente,

se ha encontrado bases de eso,

porque acá en la chorrera donde,

tengo un lotecito,

allí se encontró como dice el cabello ollas todo eso,

y no hace mucho que hallaron hasta la olla de chicha.

si?

tons eso aguanta,

eso sí es verdad,

pero ellos creían que pues van a salir de nuevo,

no.

en la conquista de los españoles ahí quedaron sepultados.

hasta ahora se los halla pero ya muertos no vivos.

(a)

en cuanto a nuestro territorio,

pues según (la) la estadísticas (gu) gubernamentales,

pues piensan como dice no acabarlo (no) no eliminarlo,

sino que pues terminar los resguardos porque eso es lo que está el gobierno actual,

que ya terminar los resguardos,

y (ya) pues termina los resguardos y acabaría la autoridad si tradicional,

pero eso pues son grandes luchas que se está emprendiendo,

y no se dejará terminar.

si?

no dejaremos terminar,

porque si nuestros mayores lucharon por un derecho propio, 
ahora en la actualidad pues también tendríamos que defendernos como dice como toque.

eso no tendría que,

que terminar le resguardo ni tampoco la autoridad tradicional.

porque según la constitución y las leyes,

la autoridad,

tradicional es (un) de caracter público.

si?

pues sobre la chagra,

el cultivo es muy como le digo prehistórico de nuestros mayores.

que hay que motivarla que cambió evolucionó diferente,

correctísimo eso ya terminó,

pero ahorita se trata de que la chagra nuestros mayores con ella sobrevivieron,

$\mathrm{y}$,

y se alimentaron sanamente,

no utilizaban químicos,

nunca,

y (la) en cuanto a la previsión del tiempo ello eran sabios,

que lo manejaban de acuerdo a las fases de luna,

ellos no sembraban en cualquier tiempo.

no tampoco utilizaron químicos,

para poder solventar sus productos.

era todo orgánico.

por eso ellos la resistencia fue muy larga.

vivieron largo tiempo,

no como ahora ya (la) nuestra chagra pues está contaminada,

nuestros productos es de puro químico a la,

se los hace criar como dice a la brava,

tonces,

de eso pues la chagra tiene un valor,

ahorita como le digo ahí se,

se está implementando con nuevas personas,

y dando capacitación a la gente,

para que vuelvan a retomar lo de antes de la propia chagra para alimento propio de la familia.

la planta en cuanto a plantas medicinales,

de acuerdo eso es,

no las puede tocar cualquiera,

si?

cogerla lo menos,

eso es comprobado porque (yo si veo) en esto si les doy un ejemplo,

yo una vez para ver si cierto era (que se) que se secaban,

cogí unos frutos de una mata de ají,

nuestros mayores decían que se seca llenándolo al bolsillo y (lo e) lo experimenté yo propiamente,

lo cogí lo llené al bolsillo,

y la mata se secó, 
entonces eso (si) eso es verdad.

las matas son celosas.

usted tiene que pedirle permiso,

a la planta para que pues le de,

como dice con gusto ella porque ella hablar no puede pero siente.

el sentir si siente,

entonces eso no puede coger cualquiera,

en las plantas medicinales,

a lo menos eso si es delicado y celoso,

correcto,

eso la gente esta ahorita creyendo ya,

que las cosas,

si hay espíritus,

si hay maleficio en cuanto a la humanida,

entonces la gente está creyendo y utilizando las plantas,

de la curación alternativa.

de la medicina tradicional que llamamos nosotros los indígenas.

si?

no lo que usted está haciendo su labor en superficial,

lo está haciendo es (eh eh),

propiamente en el mundo del medio.

no lo está relacionando con el mundo de abajo,

porque el mundo de abajo es la fuerza viva donde evoluciona,

todo para usted.

si?

y allá es donde nace la fuerza propia,

para que el el humano,

eh trabaje haga lo como puede llamarse,

no?

en el mundo de abajo,

[inaudivel] ellos quedaron en el mudno de abajo,

por eso anteriormente mi contesta fue,

creían que iban a salir,

pero pues se asfixiaron y murieron quedaron allí,

ellos por temor de la persecución,

de la conquista que venían los españoles,

se enterraron,

y ellos quedaron en el mundo de abajo y ya,

en el mundo del olvido,

pues porque ellos han quedado como dice superficial unos ya,

tanto la gente cultivando la tierra,

han salido,

han salido las partes de ellos,

sea lo como dice los,

lo el barro los,

las ollas que ellos tenían,

o restos de ellos mismos de los huesos, 
si eso si se ha topado es la verdad, pues ya se salen como,

la tierra no está quieta la están trabajando,

por eso es lo que todavía se halla los cementerios,

a onde tractoran.

los espíritus de,

cómo para la siembra?

o las fases de luna para sembrar la chagra?

es la es la fase de luna es la misma.

por eso que les quede claro a ustedes que la menguante es una sola,

si?

no hay luna llena,

o luna llena es la misma,

eso por eso tienen que aprender a decifrar al calendario lunar.

hay luna tierna donde comienza $\mathrm{y}$,

esa es la crecienta,

que llega hasta la luna llena,

ahí termina o menguante,

que termina la menguante,

sigue la noche oscura.

y ahí ya sigue la merma,

que decimos nosotros,

ahí es onde,

busté puede accionar,

tiene todo el derecho para trabajar hacer lo que quiera.

en estas fases de luna,

también tiene que ver para la siembra de la chagra de nuestros productos.

se siembra en crecienta,

pero hasta media parte hasta el ocho de luna,

de crecienta.

lo mismo en la merma,

también hay productos que toca sembrar en merma.

esto hay arto que dialogar pues,

esto tocaría con ampliación,

para poder dialogar y enseñarles como es la,

la la las fases de luna que se utiliza en nuestro medio,

porque sí tiene relación la luna con la tierra,

si busted no le obedece,

a la a la luna,

hace lo que quiera usted aquí en la tierra,

trabajar,

cuando busté quiere,

la daña.

eso si,

se daña.

correctísimo.

lo que yo le acabé de mencionar en antriormente, 
todos los espíritus son propensos en la luna llena.

o sea cuando la luna está grandota,

esa es la luna llena,

y ahí es donde los espíritus,

es apropiado para ellos andar o estar.

salen. 
